$\begin{array}{llll}\text { B } & 3 & 973 & 634\end{array}$ 


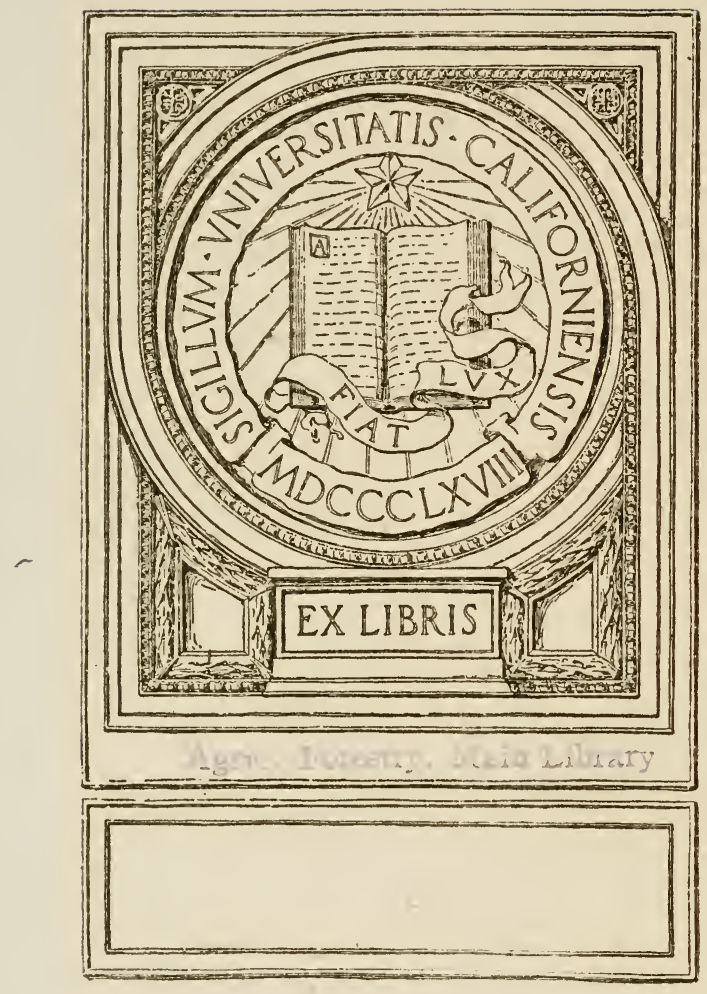





U. S. DEPARTMENT OF AGRICULTURE, FOREST SERVICE-BULLETIN No. 67. GIFFORD PINCHOT, Forester.

\section{FOREST RESERVES IN IDAHO.}

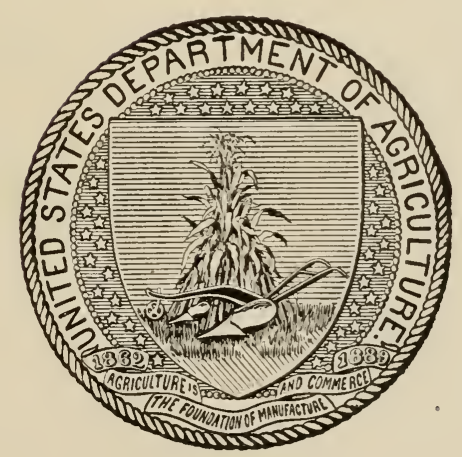

WASHINGTON:

GOVERNMENT PRINTING OFFICE.

1905 . 
Agric,-Iorestr, Mant Library

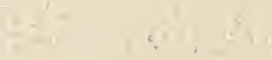

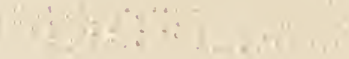




\section{LETTER OF TRANSMITTAL.}

\section{U. S. Department of Agrictluture, Forest Service, \\ Washington, D. C.. July 9.5. 190.5 .}

Sir: I have the honor to transmit herewith copies of correspondence and papers relating to the creation of forest reserves in Idaho. and to recommend their publication as Bulletin No. 67 of the Forest Service. under the title " Forest Reserves in Idaho."

The President having authorized this publication in view of the questions raised as to the propriety of creating these reserves, the material has been prepared in obedience to his instructions received through you.

Very respectfully,

Gifford Pinchot,

Forester.

Hon. Jayes Wilson,

Secretary of Agriculture. 

Senator Heyburn to the President - . . - - - - - - - - - - - - -

The President to Senator Heyburn _. .

Mr. Loeb to Secretary Hitcheock . . .

Senator Heyburn to the President . . .

Senator Heyburn to the President . . . . . . .

Affidavit of E. J. Roberts . ...

Affidavit of E. M. Gilpin ....

Affidavit of W. J. McConnell _. _...

Affidavit of Thomas F. Hanley

Senator Heyburn to the President ...

Mr. Pinchot to the President. . .

Report on Senator Heyburn's letters on Idaho forest reserves _. . . . . . 19

Senator Heyburn to the President ... . . . . .

Senator Heyburn to the President . . .

Senator Heyburn to the President . . . . . . .

Senator Heyburn to Mr. Barnes $\ldots \ldots$ 2r

Senator Heyburn to the President

Mr. Loeb to Mr. Pinchot. ...

Mr. Pinchot to the President . . . . .

Mr. Pinchot to Senator Heyburn . . . . . . . . . . . . . . . .

Mr. Pinchot to the Acting Commissioner of the General Land Office ..... 35

Senator Heyburn to Mr. Pinchot ... . . . . . . . . .

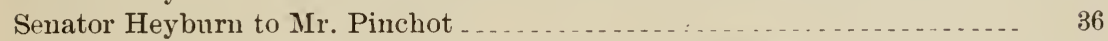

Senator Heyburn to the Commissioner of the General Land Office . . . . . . . 36

Mr. Pinchot to Senator Heyburn _. _ . _ _ . 39

Mr. Pinchot to Senator Heyburn .

Mr. Pinchot to Senator Heyburn . .

Senator Dubois to the President $\ldots \ldots \ldots$

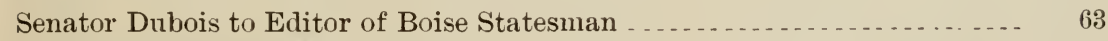

Senator Heyburn to Mr. Pinchot . . . . . . . . . .

Senator Heyburn to the President . $\ldots \ldots$

Mr. Pinchot to Senator Heyburn _. _ _ _ _

Senator Heyburn to Mr. Pinchot . . . .

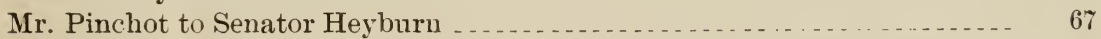

Commissioner of the General Land Office Richards to Secretary Hitchcock $\quad 6$.

Commissioner of the General Land Office Richards to Secretary Hitcheock $\quad 68$

Proposed Idaho addition to the Yellowstone Reserve

Proposed Henrys Lake Forest Reserve, Idaho . . . . . . . . . . . . . 69

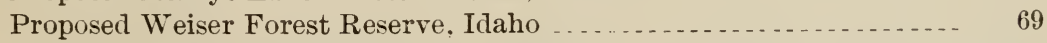

Proposed Sawtooth Forest Reserve, Idaho .....................

Proposed Payette Forest Reserve, Idaho . . . . . . . . . . . . . . . . 70

Proposed Cassia Forest Reserve, Idaho ... . .

fovernor Gooding to Secretary Hitchcock . . . . . . . . . . . . . . . . . . . . . .

Acting Secretary of Agriculture Hays to the Governor of Idaho . . . . . . . . i4

The President to Senator Heyburn _. . .

Senator Heyburn to the President ............

APPENDIX.

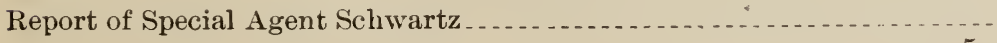





\title{
FOREST RESERVES IN IDAHO.
}

\author{
Senator Heyburn to the President.
}

Wasmington, February 29, 1904.

The President:

Pursuant to your recent request that I submit some suggestions in reference to the withdrawal for, and creation of, forest reserves, I have the honor to submit that your order announced on the occasion of my recent interview, that no further withdrawals should be made for forest reserves, or forest reserves created, without first giving notice of such intention, together with the opportunity of being heard. to the Senators and Representatives in Congress from the State in which the reserve is proposed to be created. will in future result in much good. It has not been the practice heretofore to do so, and many withdrawals have been made for forest reserve purposes in the State of Idaho that have worked great injury to the State and done much to retard its settlement.

Under date of February 22, 1897, the Bitter Root Forest Reserve was created, containing an area of $4,147,200$ acres. This reservation covers some of the oldest settlements in the State of Idaho, some of the most important mining camps, and many ralleys adapted to agricultural settlement, also much land valuable for home-making purposes. It is not confined to the headwaters of streams or watersherls, or mountain divides, but it was created as marked out upon the map. without definite knowledge or investigation as to the character of the country.

The system as now executed is paralyzing the growth of the State of Idaho. Business men and mining investors will not invest money within a forest reserve. They will not place themselves in a position where they must ask permission to do that which they in other parts of the country may do without permission of officers. American citizens prefer to have their legal rights established by law and not by consent.

The Priest River Reserve was created on February 22, 1897, and contains 645,120 acres. This reservation contains a vast amount of land fit for home making and settlement.

Neither of the foregoing reserves are at the headwaters of streams flowing into arid regions, where there is any necessity of conserving the water supply. A large portion of the Bitter Root Reserve is not conserved with timber at all. I am personally acquainted with the character of these reservations, having passed through and orer them.

The Pocatello Forest Reserve was created September 1, 1903, containing 49.920 acres, for the purpose of protecting the sources of streams from which the city of Pocatello derives its water supply. 
It is partiall coves sith binber. It serves the purpose of keeping the stock ont of the headwater's of the streams and from the defilement of the waters constituting that city's supply.

The Coem d'Alene Forest Reserve, withdrawn on August 1t, 190:?, contains 138.240 acres. It is not loeated upon the headwater's of streams so as to conserve the water supply, and there is no occasion for the withdrawal of this reserve, except to protect the Government timber against depredations, but there are already laws enacted for that purpose that only need to be enforced: it works the greatest injury to that section of the comntry to withdraw it from settlement. There is no arid region upon any stream depending upon the water supply of this section, and furthermore this timber reserve covers one of the best mineral regions of northern Idaho, in which prospectors are engaged in locating and developing mining claims every summer.

It is now suggested by the Department to very much extend this reservation. and according to the map submitted it would appear that the proposed extension will be more than double the area of the present withdrawal, and will include the mines of the Coeur dillene country, which have produced more than $\$ 200.000 .000$ in wealth, and which are to-day producing one-half of the lead product of the United States. besides millions of dollars in silver and gold. Men will not invest capital in mines or in the development of a country under the forest reserve rules and limitations.

Henrys Fork Reservation was withdrawn on April 30. 1902. containing about 50.000 acres. This reservation lies in eastern Idaho near the Yellowstone Park. and if it is confined to the watershed lying along the Bitter Root Mountains dividing Idaho from Montana. and covering the headwater's of the streams of Henrys Fork and Camas Creek, it might serve a useful purpose. but in no instance should these reservations along the watersheds be extended down into the valleys where the land is desirable for settlement.

The Neadow Creek Reservation, containing about 135.240 acres. withdrawn on September 5, 1902. and restored on November 20(i. 1903. only resulted in tying up that section of the comtry from settlement for the period of a little short of a year.

The Sawtooth Reserve, withdrawn December 2. 1902. the boundaries being changed on september 1, 1903, still stands. It contains an area of abont 1.084 .480 acres.

The reservation to which I particularly directed rour attention on the occasion of my recent interview with you is the Little Salmon Reservation in Washington County. Idaho, containing about 681,200 acres. withdrawn on November 14, 1902, and the addition thereto in purple color. to which I directed your attention, was withdrawn on February 1, 190t, only a month since.

These two reservations comprise 30 townships and cover one of the most valuable mining regions in Idaho, and, in ardlition thereto, many valleys most desirable for settlement, convenient to a railroad. It will be observed from an examination of the map that the railroad which is under construction from Weiser, in Washington County, north to connect with the railroad coming down from the north at Harpster, in Idaho County, is closed in on either side by these forest reserves in such way as to practically tie up the country on which this railroad must depend for its resources, and if 
the creation of these forest reserves is completed the railroad will doubtless stop where it is. It can not afford to build through a country that is included within forest-reserve restrictions. The future of Idaho depends upon the number of people who make their homes within it, and this is regulated by the amount of available, unembarrassed territory subject to appropriation as homes under the land laws of the United States.

I submit herewith a copy of the contract which settlers are required to sign who would go within the forest reserve for the purpose of settling or transacting business. It will appear, in view of the fact that many of the important towns of Idaho are already included within forest reserves, that such restrictions will ultimately result in driving all settlement and business beyond the reservation lines. The American citizen will not consent to take, at the will of any man, the right which the law gives to others and should give to him. These restrictions are harmful.

On the occasion of our recent conference regarding this matter you asked me directly as to whom I complained of and what officers my criticism is directed to. I was not sufficiently advised at that time as to who was responsible for the several steps in the creation of forest reserves to answer specifically. I am now advised that the withdrawals for forest reserves are first suggested by the Chief of Forestry in the Agricultural Department: that his recommendations are acted upon by the Secretary of the Interior acting through the Commissioner of the General Land Office. Upon making inquiry in regard to this matter I had been referred from one of these Departments to the other, and was at the time of my conference with you not so fully advised in regard thereto as I am now.

Idalio can not grow under the restrictions that are placed upon it. I am not opposed to creating forest reserves for proper purposes, but I insist that they should be created upon the ground and not upon the maps; that is, from information obtained on the ground, and not by drawing lines upon the map. I also submit that they should be created only after full and thorough consultation with those representing the State.

I would call your attention to the fact that some of the withdrawals that have not yet been acted upon have stood for periods of two or three rears. These withdrawals are just as effective in preventing settlement as though the reservations were created.

I have had the area of the forest reserves actually created, the withdrawals actually made, and the proposed or suggested withdrawals computed:

Acres.

The existing reserves under Executive orders aggregate

$4,8+2,240$

The existing withdrawals aggregate about

'The suggested withdrawals now under consideration aggregate

about

$5,156,2+0$

$3,225,600$

Making a grand total of about

$13,224,080$

I attach hereto a copy of the rules heretofore referred to and also a casual map of one of the mining camps within the Bitter Root Forest Reserve. There are many other mining camps on this and other forest reserves in Idaho.

I realize, Mr. President, that I have already been more elaborate 
than would seem to be justified, but the question is a large one and it is impossible to present all of the features necessary to be considered within the scope of a proper response to your suggestion.

It will be very gratifying to me if, at a convenient time to yourself, the matter can be taken up personally and by the process of direct suggestion and interchange of ideas we can readily dispose of the inore important questions arising out of the controversy. I desire to be understood as not being an enemy to forest reserves, but, on the contrary, as being farorable to their creation for proper purposes, but at all times keeping open to unembarrassed settlement for homemaking purposes. entry for mining and kindred uses, those lands adapted to such purposes. The State of Idaho is very much interested in this question. It has certain rights to select lands under the admission act, and its right in this regard is diminished to the extent of forest reserves and withdrawals. and it should be entitled to a hearing when such withdrawals are proposed. I hope the law may be so amended as to give bona fide settlers the free right to select any part of the public lands as homes, freed from unusual restrictions incident to forest reserves.

Respectfully submitted.

\section{W. B. HeYbers.}

The President to Senator Heyburn.

Washington, March 2. 190\%.

Mr DEAR SExator Herbirix: I have referred your letter for full report to the secretary of the Interior. Let me, however. correct one misapprehension. I have clirected that no forest reserves be made without consultation with you, but I did not direct that there should be no withdrawals of land preliminary to an examination of the subject. It would be impossible to notify anyone in advance about there withchawals, as I am informed. unless at the risk of adrantage being taken thereof for improper reasons; and so, as I understand it, no one outside of the ()ffice is ever consulted. I shall, however, take it ilp with the proper authorities to find out the reasons. sincerely. yours.

Hon. IV. B. HeYBurs,

Theodore Roosevelt.

United States Senate.

Mr. Loeb to Secretary Hitchcock.

Washington, March 2, $190 \%$.

My Dear Mr. Secretary: By direction of the President I beg to send you the inclosed letter from Senator Heyburn, with accompanying maps, in reference to forest reserves, and to say that the President would like a full report on it from Commissioner Richards and Mr. Gifford Pinchot.

Very truly, yours,

Wм. Lоев, Jr.

Hon. E. А. Нiтchсоск. Secretary to the President.

Secretary of the Interior. 
Senator Heyburn to the President.

\section{The President :}

Washington, March 15, 190\%.

Further referring to your letter of March 2, relative to withdrawal for forest-reserve purposes, wherein you correct a misapprehension .on my part, I would suggest that any information which the Department should give to a Senator in confidence would be safely deposited, and members of Congress could safely be intrusted with any detail as to the plans of the Department affecting lands in the States represented by them. Their interest in the welfare of their State is coextensive with that of the General Government. The proposed preliminary withdrawal of lands is one upon which they could generally give valuable information. Their residence in the State, coupled with an intelligent study of the interests to be affected by the withdrawal, would render them useful counselors, and I can not think it possible that they would disregard their public duty in such way as would enable anyone to take an improper advantage of the contemplated action of the Government.

The withdrawal of land from settlement is as effectual to prevent settlement as the creation of forest reserves, and in more than one instance such withdrawals have been in force for a year or more when the action of the Department in making the withrlrawal has been reconsidered and the lands restored to settlement, but at the expense of the prosperity of the State.

The question is one of paramount interest to our States. The Government holds the lands therein in trust for the present and future inhabitants of the State only. Neither the timber or any other resources should, in my judgment, be considered a fund upon which the East or any outlying section of the comtry may draw to increase its prosperity. If other sections of the United States have squandered their natural resources in the past, they should only be allowed to draw upon those of the new States subject to the present and future necessities and to the general welfare of the citizens of the States.

I am not antagonistic to the system of forest reserves, but I am opposed to the creation of such reserves at the expense of the home maker, and I believe in the right of individual selection by the settler within as wide a field as possible, and I sincerely hope that I may. together with the other representatives from my State, be advised of contemplated action on the part of the Government in any respect where the matters above referred to may be affected.

Sincerely, yours,

W. B. Heyburs.

The matters referred to in Senator Heyburn's letter of February 29, 1904, were then talked over in a conference between the President, Senator Heyburn, and Mr. Pinchot. 


\section{Senator Heyburn to the President.}

\section{Washington, May \%, $190 \%$.}

\section{The President :}

Pursuant to my agreement to submit some facts and suggestions in regard to the forest reserves in Idaho, and especially as to their relation to mineral lands. I beg to submit the following:

The map hereto attached shows the reservations existing, those for which withdrawals have already been made, and those proposed but not yet withdrawn. The black areas represent the lands the title io which has passed out of the United States to settlers and to the State. The small black squares are sections numbered 16 and 30 and constitute the lands set apart for school purposes.

I have marked upon this map in red ink the recognized and determined mineral lands where prospectors and miner's are actually engaged in mining.

The act making appropriations for sundry civil expenses of the Government of June 4, 1897 (30 Stat. L., 34-36), provides, among other things:

No public forest reservation shall be established excent to improve and protect the forest within the reservation, or for the purpose of securing favorable conditions of water flows and to furnish a continuous supply of timber for the use and necessities of citizens of the United States; but it is not the purpose or intent of these provisions, or of the act providing for such reservations, to authorize the inclusion therein of lands more valuable for the mineral therein or for agricultural purposes than for forest purposes.

The Supreme Court of the United States has designated those lands as mineral upon which the prospector is willing to spend his time and labor with the expectation of finding pay ore. 'The area embraced within the proposed reservation covering the Coeur d'Alene mining country is all mineral lands. There are hundreds of mining claims actually operating and one-half of the lead of the United States is produced within this proposed reservation. 'The mines have been in active operation for twenty years. New claims are being located and new mines opened every day. The product of the territory included within this proposed reserve for the past year anounted to upward of $\$ 9,000,000$, and during this year will reach twelve millions if the country is not paralyzed by being made a reservation.

The west half of the Bitter Root Reservation is all mineral land; in fact within its boundaries are the oldest mining camps in the State of Idaho, and there has been produced from the mining camps in the west half of this reservation more than $\$ 50,000,000$ in gold.

The proposed addition withdrawn in the Cour d'Alene country comprising 6 townships, or about 138,240 acres, is entirely within a mineral country in active operation. The Seven Devils country lying along the Snake River, where those words occur on the Oregon line, is a mineral country of great present importance and of the very greatest future promise, and contains some of the finest bodies of copper ore known to exist in the country, besides both gold and silver mines. The proposed reserve lying farther south, near the city of Boise, covers the Boise Basin mining country, which is now and has been continuously mined since 1863. This country has produced upward of $\$ 150,000,000$ in gold and is still an active producer.

The mining sections of Idaho as a rule are well timbered, and it is 
fortunate that such is the case, as vast amounts of timber are absolutely essential to the development of mines. The sections where the mines are situated are as a rule valuable only for mining. The mines in northern Idaho are all in humid regions and the creation of forest reserves does not conduce to the usefulness of the water supply to any extent whatever, and the claim made on behalf of forest reservations as affording protection from fire, is, from actual observation and cxperience of those who are in a position to know, largely a theory. The countries in which forest fires are unknown or are under control are those which are inhabited. No person having a real interest in the country would ever promote or permit a fire to destroy the forests.

You asked me for a statement from some real mining operators and miners who are familiar with the question as to whether or not the cxistence of forest reserves detracted from the availability and usefulness of the country for mining purposes and acted as a deterrent to those who would invest in mines within forest reservations. I hand rou herewith the affidavits of some of the extensive mining operators of the Pacific States. First is that of E. J. Roberts, who is general manager of the Federal Mining Company and other mines, which produce more than one-fourth of the lead of the United States. He is a practical mine manager of experience and exceptional intelligence. He says that he would not invest in mines within a forest reservation, and it is upon the judgment of such men as Mr. Roberts that investments are considered and determined.

I also hand you the affidarit of E. M. Gilpin, who is a prospector of many year's' experience, and who gives you cogent reasons why men will not prospect for mines within forest reserves with the same freedom as in case the forest reserve did not exist.

I also hand you an affidavit to the same purpose from W. J. McConnell, who is largely interested in mining in Idaho, and who gives in a concise manner his objections to the existence of forest reserves covering mining lands.

I also hand you the affidarit of Thomas F. Hanley, one of the oldest prospectors on the Pacific coast, who gives you his views on this matter.

Mr. President, the theory that the existence of forest reserves does not interfere with mining is not suported by experience, and as I stated to you in my personal interview, men will not buy mines within a forest reserve at the same price, nor will they expend money upon them as freely as upon mines disassociated from the rules and restrictions of forest reserves. The affidavits state the matter very plainly, and no theory that can be presented as to how these men should look at the matter is a sufficient answer to the facts as to how they do consider it.

It is of much more importance that Idaho's mines be developed than that the forest-reserve lines should be projected upon the people of the State in such manner as to deter or in any way discourage mining in the State.

Forest reserves in north Idaho have done very much to prevent settlement in that portion of the State, and the threat embodied in the withdrawals and proposed withdrawals for reservations in south Idaho has detracted immensely from the interest the emigrating population naturally takes in a State wherein are to be found public lands. 
The people of Idaho have no desire to destroy its resources. They are intelligent, conservative, and safe people, engaged in the building up of a great State of homes, and you may trust to their integrity and honor to as great an extent as you can trust the people of any State in the Union.

I most earnestly request that the withdrawals that have been made for forest reserves in north Idaho be canceled speedily. Every day that they exist interferes with the advancement of the country. The Coeur di Alene country should have no forest reserve upon any part of it. and I respectfully request that orders shall be issued to that effect. The Seren Devils mining country referred to is purely a mining country and should be reliered of that burden. And the proposed withdrawals and the withdrawals already made anywhere within the red lines which I have marked around sections of the map should be canceled.

I accompany this report with a number of petitions for the cancellation and change of the forest reserves in Idaho, which will give you some idea of the expression of discontent emanating from the people of that State. and when so many and so important a portion of the people of any State express their disapproval of the policy of the Gorernment, the center of which is so far distant as Washington is from Idaho. I would suggest that an examination into the reasons given by these protestants should be through channels in a position to determine the right and justice of the matter.

I would dwell upon the limitation of power contained in the act, wherein it is provided that lands more valuable for mineral or agriculture shall not be included within forest reser'ves. Notwithstanding the existence of this prohibition two or three of the greatest mining camps in Idaho and in the world to-day are proposed to be, and are already, within forest reserves. I maintain that the power does not exist to create and maintain forest reserves under such circumstances, and that where the power has been inadvertently exercised the error should be speedily corrected.

$$
\text { Sincerely, yours, }
$$

II. B. HeYbURx.

\section{State of IdAHo, \\ County of shoshone, ss:}

E. J. RoberTs, being first duly sworn. on his oath deposes and says :

That he is engaged in mining in the state of Idaho in the Coeur d'Alene mining district, and has been so engaged for more than three rears past.

That he is general manager of Federal Mining and smelting Company and is familiar with mining in all of its branches. That he is familiar with the creation of forest reserves and with the rules governing the same and with the mining within forest reserves. That he has recently been advised that there is a possibility of the creation of a forest reserve to cover the Coeur d'Alene mining region and country adjacent thereto. Affiant further says that he recognizes the benefits and necessity of preserving the water suppls in the arid regions, but that the section of the State of Idaho north of the Salmon River is not arid and no part thereof is arid. That the Coeur d'Alene River and its tributaries is the principal stream in shoshone County, and the only stream draining that portion of Shoshone county adjacent to and surrounding the mines in the Coeur d'Alene mining district. That the said Coeur d'Alene River runs through a country no part of which is arid and flows into Lake Coeur d'Alene, which is a natural storage basin for the waters of the Coeur d'Alene and other rivers, and in which there is sufficient water for all purposes at all times. That all of the lowlands around said stream are orerflowed during large portions of 
the sear, and the same are of much less value than if they were not subject to such overflow and if the quantity of water coming down said river was not so great. That none of the water of the Coeur d'Alene River is used for irrigation. That the other streams in Shoshone County flow through a humid country and not through an arid district.

Affiant further says that prospecting and mining are one and the same enterprise, prospecting necessarily preceding the development and operation of the mines. That while forest reserve regulations allow the location of mines within the forest reserves, the restrictions thrown around the occupation of forest reserves are such as to deter men from either prospecting or mining within such reserves, as they can only do so at a great disadvantage.

Aftiant further says that he is the owner of mining claims within forest reserves. That he would not invest in mines in forest reserves, for even after a prospector has discovered such a mine it is hard to find a ready market for it. Many mining men absolutely decline to engage in mining within a forest reserve, and it is only under exceptional circumstances that a mining claim within a forest reserve is saleable at its true value. One reason for objecting to operate within a forest reserve is that the restrictions are such that the miner is hampered in the right to use timber necessary for the development of the property, and it becomes necessary for him to secure permission from some agent of the Government for almost everything which he does in developing his claim, in building trails and roads to it; and much of the time and money which should be expended in the development of the properties is expended in trips for the purpose of securing permits from the various supervisors and other officers within the reserve. Under the rules governing the reserves a miner has no right to take any timber, except such as is on his mining claim, for the derelopment thereof. It is often the case that there is no timber upon the mining claim, but sufficient adjacent for the purpose of the miner, yet he must either violate the rules and regulations of the reserve, and lay himself liable to penalties for the violation thereof, or secure a permit to cut timber elsewhere than upon his claim, which can only be done through the Department, thus causing great delays. The timber upon the Coeur d'Alene River and its tributaries is valuable and necessary for the operation and development of the mines in the district. The timber upon the mining claims themselves has all been cut, and it is necessary to go upon the adjacent lands to secure the timber for the actual use in the operation and development. To deny the miners in the Coeur d'Alene the privilege of using the timber on the adjacent lands would be practically to require them to go elsewhere than within the county for their mining timbers. All of which would work great detriment to the mining interests of the country and would deter others from investing and serve no good purpose, ior the reason that the water supply within this section of the State of Idaho is ample at all seasous.

\section{E. J. Roberts.}

Subscribed and sworn to before me this 25th day of April, A. D. 1904.

WhliaM II. BattiNg, Notary Public.

\section{State of Idaho, County of shoshone, ss:}

E. M. Gilpin, being first duly sworn, on his oath deposes and says :

That he is a citizen of the State of Idaho, residing in the county of Shoshone. That he is by occupation a prospector and miner, and that he is familiar with prospecting and mining in all its branches. That he has been engaged in prospecting for eighteen years. That he is familiar with forest reserves and the rules and regulations thereof, having prospected within forest reserves.

Affiant further says he has been informed that it is proposed to place the Coeur d'Alene River and the comntry surrounding the same, including the leadproducing section of the Coeur d'Nlene, within a forest reserve. Having experience in mining within forest reserves, affiant says he believes the same would be a great detriment and drawback to the development of the country. That affiant has had experience in endeavoring to interest capitalists and mining men in mining claims within forest reserves. That mining men of experience object to investing in forest reserves unless the showing is an exceptionally good one, the fact that the prospect was located in a forest reserve being such a drawback as to deter them from investing there, Affiant says when it becomes necessary 5245-No. 67-05 M- 
to secure timber for the development of the claim that the rules of the reser only permit timber to be cut from the mining claims themselves.

Affiant further says that while engaged in mining in the Buffalo Humi trict within the Bitter Root Forest Reserve he, together with other's, we: bidden to cut sufficient timber to make cabins in which to live. Tha: prospectors thereabouts were notified not to cut any timber. That such :tions and rules made prospecting onerous, and prospecting continually uic. supervision of agents of the Department was unpleasant and burdensome in extreme.

Affiant further says that it is impossible to develop quartz ledges without 1 use of timber. That it is necessary in the development and working of al! mines, and that when unreasonable restrictions are thrown around the cutturs of timber it is practically putting restrictions upon prospecting and mining.

Affiant is familiar with the territory adjacent to and along the Coeur d'Alene River and its tributaries. He knows that no part thereof is arid, but that :? all seasons of the year the same is well watered. That all the lowlands a!n? the Coeur d'Alene River are overflowed during great parts of the year, . the water supply, instead of being too small, is too great. That sections of the country which would be included, as affiant is informed, within the proposei reserve, would be far distant from points of connection and from the heac quarters of the supervisors. That it would require much time in traveling bact: and forth between the office of the supervisor and the mining clains which might be located for the purpose of securing permission to do various things, such as to cut trails, make roads, and otherwise develop and make possible the development of the mining claims.

\section{E. MI. Gilpin.}

Subscribed and sworn to before me this 25th day of April, A. D. 1904.

William H. Batting, Notary Public.

The undersigned, being first duly sworn, deposes and says :

That his name is W. J. McComnell. and that his age is 64 vears; that he nas been a resident on the Pacific coast for forty-four years, during nearly all of which time he has been interested in mines and mining. His present business is the operating of mines and the promotion and sale of mining properties.

One of the greatest embarrassments being encountered at the present writing in the mineral belt located on the Clearwater and Salmon rivers and their tributaries is the forest reserve covering that locality.

A compliance with the rules governing forest reserves seriously retards the development of mines and mining prospects. Inder the law the mine owne; or the owner of a prospect is at liberty to cut timber off of any one of his claims or all of them for the purpose of working or developing the particular claim on which the timber is found, but has no right to appropriate any timber outside of the lines of his mining claims. Now, therefore, as it quite frequently occurs that mineral is discovered upon high rocky cliffs where no timber is found, before proceeding with his work it is necessary to make a pilgrimage. often consuming many days, to find the superintendent of the forest reserve or some of his rangers to make the necessary application.

In a locality like that of the Bitter Root Range, where the winter snows do not disappear until July, and begin to fall again in September, these delays are a serious detriment and materially reduce the value of the properties which may he discovered on the reserve; even such trails and wagon roads as are necessary to development can not be attempted without the consent of the Secretary of the Interior, thus consuming additional valuable time. There was a discovery made some time since near the summit of the Bitter Roof Range, in Shoshone County, near the northeast corner of the Bitter Root Iiesel've, work upon which is practically suspended pending an effort to have the district excluded from the reserve by modifying its lines. Much of the district where these prospects have been discovered has been denuded of timber by fire, and, as the altitude is so high, but little second growth has taken place. What there remains standing of the original timber is principally black or lodgepole pine, which, while it could be used for mining purposes, has but little, if any, conmercial value.

IV. J. MCCON NELL.

Subscribed and sworn to before me this 15th day of April, 1904. 
I, the undersigned, being first duly sworn, depose and say :

That my name is Thomas F. IIanley. That I lave been a resident of what is now the state of Idaho for over forty rears, engagerl most of the time in prospecting and mining. I was formerly the sheriff of Shoshone County, before rur admission as a state. I am familiar with the country now embraced witlin the limits of the Bitter Root Forest Reserve, and am aware of the difficulties to be encountered by miners and prospectors under the rules governing forest reserves. Especially do these rules hecome embarrassing when applied to the northeast portion of the reserve, owing to its long distance from the headquarters of the supervisor, who is located at Lewiston, Idaho, it being impossible during six or eight months of each year to reach him at all, and, under the most farorable circumstances, it requires from five to eight days to reach his office, and after arriving there he is frequently not to be found. In the localicy I name but little, if any, timber is growing on the claims now located, the fire having denuded almost the entire mountain many years ago; consequently the prospector has no timber on his own claim, or at most but little, and necessarily must get it elsewhere; consequently must make application or become a trespasser hefore he can proceed with his work. Under paragraph No. 10, page 13, of the Forest Reserve Manual, he may be considered a needy person and, by making a pilgrimage to the forest supervisor, if he can locate him, may be permitted to cut a load of dry firewood, the supervisor having authority to grant such privilege without marking or measuring the material; but, as noted in paragraph $\mathrm{C}$, no unmarked live timber can be cut, therefore it will be necessary not only to find and obtain the consent of the supervisor, and the indorsement of the Secretary of the Interior, but also to await such time as a forest ranger or other officer can go in and mark the timber. Paragraph No. 2, page 21, of the Forest Reserve Manual, specifies that "all applications in any reserve will be held up and delayed whenever it becomes evident that the reserve force for any reason whatever fails to carry out the work according to the prescribed regulations." Thus the prospector and miner is subject to the delay of finding the supervisor and having his application farorably considered by the Department, but is also responsible for the delinquencies of the reserve force.

Under the regulations governing the building of roads and trails on forest reserves (see p. 5, Manual), it would be readily understood that approximately one entire season will be consumed in obtaining the proper permit. The snow lies on the ground until late in June and commences to fall again in September, and, as application can not be intelligently made until the snow is off, by the time the permit is granted, after a full investigation has been made by a forest officer, the season has been entirely consumed.

The necessity of a compliance with the foregoing rules and others equally as absurd retards the development and promotion of mining prospects on forest reserves, prevents the investment of capital, and converts al hitherto patriotic and loyal class of citizens into a community of trespassers and violators of the law. Feeling that the Govermment is against them, they are against the Government. They can not go on to the reserve in the district I mention and abide there as prospectors and miners without becoming lawbreakers and inevitably being classed as criminals.

Thomas F. HaNley.

Subscribed and sworn to before me this 19th day of April, 1904.

Fred Veatch,

Notary Public, residing at Moscow, Idaho.

Senator Heyburn to the President.

\section{The President:}

Wasmington, June 2, 190\%.

Referring to our conversation this morning in regard to the withdrawal of the order of withdrawal from settlement of certain land in the Coeur d'Alene mining region, Shoshone County, Idaho, with a view of determining the advisability of embracing the same in a forest reserve. I would suggest that the time within which MIr. Pinchot was instructed to act in the matter expired a month ago. I earnestly hope that you will issue an order at the earliest possible 
date vacating all the withdrawals for forest reserves in northern Shoshone County. I recall to your mind the fact that I stated that these lands were mineral in character, and that they are in a humid region; that the creation of a forest reserve as suggested will greatly retard the development of the mineral resources and the material interests of that section.

Yours, very truly,

W. B. Heyburn.

Mr. Pinchot to the President.

Washington, June 12, 1904.

Dear Mr. President : I inclose herewith a general reply to Senator Heyburn's communications concerning forest reserves in Idaho. In addition I want to recall to your mind a conference between yourself and Senator Heyburn, held at your office some time ago, at which I was present. During the course of that conference an agreement was reached between yourself and Senator Heyburn as to what reserves should be created during the coming sunimer in Idaho, and what areas held as withdrawals pending further discussion. Senator Heyburn took the general position of approval of all reserves which were to be created for protecting the water supply of irrigated districts. In particular it was specifically agreed, and I recall very clearly going over the agreement in detail in your presence with Senator Herburn to avoid any possible mistake, that the reserves of southern Idaho, including the Henrys Fork, the Idaho addition to the Yellowstone, the Payette, and the Squaw Creek division of the Weiser, and the Sawtooth, should be created at once, while the Seven Devils division of the Weiser, in addition to the Bitter Root, the Coeur d'Alene, and the Priest River addition should be held in their present condition pending further discussion. In his letter of May 7 , Senator Heyburn throws this agreement completely over without even referring to it, and asks for the immediate restoration to the public domain of all the reserves but two.

There is no need to discuss whether or not the President has the right to create forest reserves in mineral regions further than to say that he has done so continually from the beginning of the forestreserve policy, and that the Interior Department has distinctly held in favor of his right so to do. The question whether any land is more valuable for the mineral therein or for agricultural purposes than for forest purposes is distinctly one to be determined by the Executive, and the mere fact that land is mineral in character has no bearing whatever upon the comparison of values which the law directs the Executive to make.

The mineral interests of Idaho are obriously passing through and out of the condition of opposition to forest reserves, which has been held and abandoned by the people of other great mining regions in the United States. There is every reason to believe, and there are strong actual indications, that the miners of Idaho will rapidly abandon their present untenable position for precisely the same reasons which have led to the abandomment of the same position elsewhere.

Very sincerely, yours, 
JUNE $11,1904$.

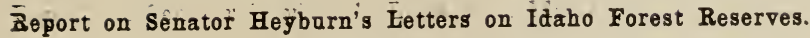

\author{
BHITTER ROOT:
}

In discussing the effect which the existing Bitter Root Reserve has upon the State, Senator Heyburn says:

This reservation covers some of the oldest settlements in the State of ldaho, some of the most important mining camps, and many valleys adapted to agricultural settlement, also much land valuable for home-makinng purposes. $* * *$ The system as now executed is laralyzing the growth of the State of Idaho. Business men and mining investors will not invest money within a forest reserve.

The Geological Survey, in its Twentieth Annual Report, has this to say of these lands adapted to settlement and agriculture:

The land fit for agriculture in the Idaho portion of the Bitter Root Reserve is limited to a few localities, and the acreage is small. The canyon-like formation of the lower portion of the Lochsa and of the entire Selway and Salmon River valleys precludes the existence of any considerable tract of arahle bottom lands along these streams. The hillsides are everywhere too steep for cultivation, and the meadows existing on some of the upper tributaries of the South Fork of the Clearwater and the head of nost of the tributaries of the Lochsa, the Selway, and the Salmon River drainage within the reserve, are either too marshy or too frosty, owing to their altitude, to permit of the growing of crops. Farming, or more properly gardening, is carried on in the valley of the Middle Fork at a place known as Syringa, about \& miles below the junction of the Selway and Lochsa, where there are two farm lecations with a total of 20 acres under the plow and a possibility of 100 or 120 more ly clearing off the forest. Above this, at the junction of the Selway and the Lochsa, are two more farms. each with 15 acres under tillage, and a possibility of adding 10 or 15 more by clearings. There is one ranch location in the Selway Valley about $\tau$ miles above its mouth, with no clearings. Along the Salmon River there are patches, varying from 2 to 25 acres in extent, as far down as IIorse Creek, in the aggregate 200 or 250 acres. * * * The grazing lands within the reserve consist of the large meadows scattered on the upper tributaries of the South Fork of the Clearwater, Elk Creek, American, Red, and Crooked rivers, with the rery numerous lesser ramifications of the same along the smaller affluents of these streams and a tract on Little Camas Prairie, between the Lochsa and Lolo forks, of about 8,000 acres. They contain in the aggregate between 7,000 and 8,000 acres. A considerable portion is occupied by permanent settlers and utilized for hay lands and pasturage.

It appears, then, that including everything which can be called agriculture in any sense, whether merely wild hay land or already under valid settlement and so unaflected by the reserve, the entire Idaho portion of the reserve contains but 9.000 acres of agricultural land, or less than three-hundredths of 1 per cent. As to the paralyzing influence upon business and mining. it is probably true that there have been instances of annoying overzealousness and officiousness on the part of minor officers. but it is equally true that many residents have refused to comply with the perfectly reasonable conditions. Moreover, the recently recommended elimination of areas around Buffalo Hump and Elk City, the only important camps, will remove practically all such complications.

\section{PRIEST RIVER.}

Senator Heyburn passes next to the Priest River Reserve, which he says contains 645,120 acres and "a vast amount of land fit for home making and settlement." 
But $5+1,160$ acres of this reserve are in Idaho. Of this area less than 9,000 acres, or 1.6 per cent, are susceptible of any form of agriculture, and over half of this is patented or minder valid claim. The remainder should undoubtedly be made available for settlers. and will be on the passage of the law recommended for that purpose by the public lands commission. It consists of seattered meadows, which do not warrant any general elimination. The proposed addition to this reserve in Idaho contains no homestead entries, and, by the most liberal estimate, not over 1.800 acres, or 0.3 per cent, are at all suitable for agriculture. The old classification of the Northern Pacific grant estimated about 40 per cent of this area to be mineral land, but it did not prove to be so and prospecting has long been abandoned. The Continental mine, on the summit of the Cabinet Range, near the Canadian line, is the only raluable prospect in the entire addition.

COELR D'ALENE.

Of the temporary withdrawal of 138,240 acres for the proposed Coeur d'Alene Reserve, Senator" Heyburn asserts that "it works the greatest injury to that section of the comntry," and that " it covers one of the best mineral regions in northern Idaho." While this statement is not final, since the region is merely in the prospecting stage, it is most easily disposed of by recalling that prospecting and location are not disturbed by reserve regulations. Senator Heyburn is under the impression that the reserve as now proposed "will include the mines of the Coeur d'Alene country. which have produced more than $\$ 200,000,000$ in wealth, and are to-day producing one-half of the lead product of the United States, besides millions of dollars in silver and gold." Here he is misinformed as to the area contemplated to be reserved, for the only actual producing mining operations within it are the Beaver Creek placers. The large mines he refers to lie south of the proposed reserve. He adds that " men will not invest capital in mines or in the development of a country under the forest-reserve rules and limitations." Of this statement it is sufficient to say that the whole history of the forest reserves is in diametrical opposition to it. both as to mining and as to other industries.

The Coeur d'Alene Reserve is designed almost wholly to preserve for the rery mining industry he champions its only practicable future timber supply. which at best is inadequate for the future, and is already sought by export lumbermen. In his letter of March 15 Senator Herburn says: "The Gorermment holds the lands in trust for the present and future inhabitants of the State only. Neither the timber nor any other resources should, in my judgment, be considered a fund upon which the East or any outlying section of the country may draw to increase its prosperity."

Although with another object, he here presents the chief argument for the Coeur d'Alene Reserve. It is an established fact that the Coeur d'Alene mines need this timber, and no less true that the agents of lumber firms are endeavoring to locate the timber for immediate cutting and exportation to other States. In spite of the assertion that this tract is wholly mineral, six townships have recently been surveyed for the purpose of timber and stone or homestead location for timber only. 
Senator Heyburn offers, among others, an affidavit from Manager Roberts, of the Federal Mining and Smelting Company, to show that miners do not want a reserve. That this is not necessarily a repre.sentative opinion may be seen from the following quotations from Mr. E. H. Moffit, manager of the Hecla Mining Company, one of the largest in the district, concerning the proposed reserve:

-I think it a good proposition to regulate the water flow, and I think it would be a great benefit to mining operations in this particular section, provided somearrangement could be made whereby the mines could get lumber and stulls. * * * If forest reserves could be established in mining sections and permits given to cut lumber and stulls for mining purposes only, it would be a grand thing.

The forest-reserve policy is precisely that which Mr. Moffit recommends, and provision is already made in accordance with it.

Mr. W. Clayton Miller, assistant general manager of the Federal Mining and Smelting Company, although not a friend of reserves, writes an officer of the Bureau of Forestry that-

After the spring floods, which occur in April and June, extreme low water obtains in August and September. During this time the total water available at Burke and Mullan is hardly sufficient for washing purposes for a 600-ton concentrating plant, and not enough to prevent accumulation of tailings in the stream. * * * The foothills of the Bitter Root at the head of Canyon creek are almost bare and rery rocky. The head of South Fork, however, is well timbered, and considerable soil covers the rocks, so that the water is to some extent reservoired by nature.

This statement does not agree with the statements of Senator Heyburn and Mr. Roberts that water preservation is not an object in the Coeur d'Alene region.

Of the proposed Lake Henry or Henrys Fork Reserve, Senator Heyburn says that it might serve a useful purpose if confined to limits which will not include lands suitable for settlement. This is precisely the case as the lines now stand.

\section{SEVEN DEVILS (WEISER).}

Attention is directed particularly to the Little Salmon or Seven Devils area, chiefly in Washington County, which is known in this Department as the Seven Devils division of the proposed Weiser Forest Reserve. Senator Heyburn asserts that this covers "one of the most valuable mining regions in Idaho, and in addition thereto many valleys most desirable for settlement, convenient to a railroad," and that "the railroad, which is under construction from Weiser, in Washington County, north to connect with the railroad coming down from the north at Harpster, in Idaho County, is closed in on either side by these reserves in such a way as to practically tie up the country on which this railroad must depend for its resources, and if the creation of these forest reserves is completed, the railroad will doubtless stop where it is. It can not afford to build through a country that is included within forest-reserve restrictions."

It is true that this area includes some territory in which encouraging mineral prospects exist. Since their development is not interfered with, that is an argument for preserving the limited timber supply for their use and not for leaving it free for export over the projected railroad. But, although Senator Heyburn asserts that all of this is " recognized and determined mineral lands where prospect- 
ors and miners are actually engaged in mining," not over 10 per cent has any prospecting whatever.

The statement concerning agricultural lands is not borne out by the facts. This area was withdrawn from settlement very recently. During the long period prior to its withdrawal only about 11,880 acres, or 1.6 per cent, had been entered as homesteads, and a careful field examination has shown that but 15 per cent of the land so taken, or about 1,780 acres, is really suitable for agriculture. The rest was taken for timber or grazing purposes.

Of the vacant lands now under withdrawal, which Senator Heyburn says include many valleys most desirable for settlement, it is barely possible that 3,000 acres, or four-tenths of 1 per cent of the whole, might be entered under a broad construction of the homestead laws. The rainfall of this region is but 10 or 15 inches, and there are few spots where irrigation is feasible. The essential fact, however, is that althongh these 3.000 acres are withdrawn they are not within the proposed reserve. As the appended table shows, all cultivable land has been excluded by the boundary recommended.

If, as Senator Heyburn says, the object of the projected Pacific and Idaho Northern Railroad will be defeated by this reserve, that object must be solely to remore the inferior forests of the Cuddy and Seven Devils ranges, upon which a large and growing population depends wholly for an already inadequate water supply. The projected route of the road nowhere crosses the proposed reserve, so its construction could be hampered only by the segregation of some tie timber which might be within hauling distance. The insignificant amount of withdrawn farming land previously described, even were it not to be restored to the public domain, could hardly furnish any perceptible support to a railroad or seriously affect the future of Idaho.

Even the lumbering possible if the lands were left subject to the timber and stone laws will be little affected by the reserve, for all of the commercial timber available on the east of the proposed road, and most of that on the west, has already been taken up. That which is included is the commercially inferior woodland on the higher slopes, despised and left by the timber cruiser, but of incalculable value to the miner, the fuel-using settler, and the irrigator of the arid and water-needing Weiser Vallev. This reserve, as well as the Sawtooth, Payette, and Henry's Fork areas, is not only indorsed but vigorously urged by the State engineer of Idaho and the Reclamation Service. Among the evidence concerning the Seven Devils area presented by Senator Heyburn is a petition against the reserve which gives as objections the statements that no water protection is needed. that much of the area is agricultural land or barren, and that it will flood the market with "scrip." The first two of these have been answered above. The third does not bear comparison with the appended table, which shows that but three-tenths of 1 per cent of the whole area consists of lands which are apt to become base for lieu selection.

SQUAW CREEK.

Little reference is made by Senator Heyburn to the other division of the proposed Weiser Reserve (the Squaw Creek division) other than its inclusion on his map in the "determined " mineral class. As a matter of fact, one doubtful coal claim constitutes the only mining or prospecting activity in the tract. 
SАพTัก0TH.

Senator Heyburn says of the proposed Sawtooth Reserve that it "covers the Boise Basin mining country, which is now and has been continuously mined since $1863, "$ and he embraces all of it with a $\mathrm{r}^{\mathrm{e}} \mathrm{ed}$ line, signifying that it is mineral. The fact is, none of the Boise Basin mining region is in the proposed reserve. It does, however, include an entirely distinct and little developed mining district further east, so that perhaps 20 per cent of it may be called land which encourages prospecting. This reserve is probably the most important in Idaho from an irrigation standpoint, for the Reclamation Service engineers in charge of the Boise project say that this project is not warranted unless the reserve is created to insure against early run-off.

The following table shows the acreage and character of all the recommended reserves except the Sawtooth, classification of which is not complete:

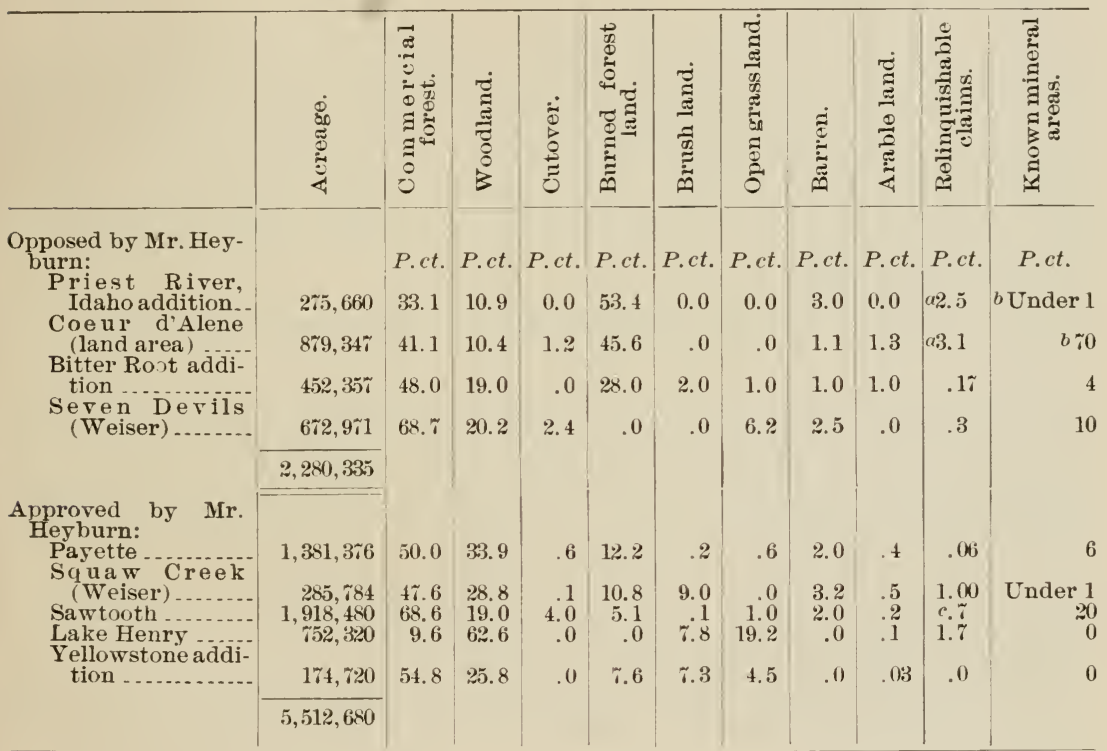

a l'ractically all railroad land.

$b$ The old official classification of mineral lands was larger, but much of the area failed to develop any showing of mineral and is no longer prospected.

c Includes surveyed State land in this instance.

Total in Idaho, $7,793,015$ acres.

It is self-explanatory, excepting possibly the figures on arable land, relinquished claims, and known mineral areas. Under arable land are included all lands worth cultivating, whether now occupied or not; therefore the area removed from possible future settlement is still smaller than is indicated. By relinquishable claims is meant all alienated lands, patented or entered, except mining claims and State lands. Known mineral areas include all land in which there is any mining or considerable prospecting, or, in other words, recognized by residents of the region as having a possible mineral value. No attempt has been made to follow the original classification made for the purpose of settling the Northern Pacific grant, because it is no longer considered of any accuracy. 


\section{Senator Heyburn to the President}

\section{The President :}

Waldace, InAHo, July 1ij, 1904.

Some time since, while en route, I was handed Mr. Pinchot's communication to you of June 12 , together with his report on my previous letters addressed to you in regard to forest reserves in Idaho. They came to me through your secretary. I have not been able heretofore to make reply, because of my absence.

The first portion of Mr. Pinchot's letter is merely critical of my interpretation placed upon the conference I had with you shortly before I left Washington, and charges me with "throwing over" what he terms " an agreement made at that time withont even referring to it." Mr. Pinchot is mistaken in this, but in any event I do not feel called upon to reply to a charge made in such spirit. The recollection must rest with you as to the result of that conference.

Mr. Pinchot says:

There is no need to discuss whether or not the President has the right to create forest reserves in the mineral resions, further than to say that he has done so continually from the beginning of the forest-reserve policy. That the Interior Department has distinctly held in favol of his right so to do. 'The question of whether any land is more valuable for the mineral therein. or for agricultural purposes than for forest purposes is distinctly one to be determined by the Executive, and the mere fact that land is mineral in character has no bearing whatever upon the comparison of values which the law directs the Executive to make.

This is Mr. Pinchot's interpretation of the law. which reads as follows:

No public forest reservation shall be established except to improve and protect the forest within the reservation, or for the purpose of securing favorable conditions of water Hows, and to furnish a continnous supply of timber for the use and necessity of citizens of the Tnited states: but it is not the purpose or intent of these provisions or of the act providing for such reservations to authorize the inclusion therein of lands more vainable for the mineral therein, or for agricultural purposes, than for forest purposes.

It would be difficult to harmonize the provisions of this statute with Mr. Pinchot's conclusions as to the law.

Only lands valuable for forest purposes are intended to be included in a forest reserve by the express provision of the statute. Forest purposes inchude-

(1) Necessity for present use.

(2) Probability of necessity for future use.

(3) Availability for present use as to proximity to use and transportation.

(4) Proximity to market or probable market.

(5) Condition of timber as to variety and maturity.

These questions have not been taken into consideration by Mr. Pinchot or by those upon whose reports forest reserves have been created.

Mr. Pinchot makes what he calls "a report" on my letter on the Idaho forest reserves, and endeavors to prove that the creation of these forest reserves is justified from the fact that the land embraced within them is practically useful for no purpose. He has appended a table which upon analysis shows that there exists no sufficient 
reason for the creation of any of the reserves referred to in it; shows no necessity for the present use of the timber; no probability of the necessity for future use; no availability for the present use if such existed, because not in proximity to any present or prospective use or transportation to any market; shows nothing as to conditions of timber respecting its variety or maturity.

The inquiry arises, Why shut up vast sections of a new State against individual selection for permanent use under existing laws in the absence of a showing-

(1) That the lands belong to the Government.

(2) That they are valuable and necessary timber lands.

(3) That there is a present or prospective need for this timber.

(4) That it is available to market, including means of transportation.

The mineral value of lands in a mineral country is an undetermined quantity, but is always measured by the possible estimate in the light of experience. All mineral countries have been condemned by men inexperienced in such matters. The impressions of a theorist or one unacquainted by long and actual experience with the changing conditions representing mining sections are of no value.

Mr. Pinchot, in his report on my letter, makes a lot of dogmatic assertions as to the conditions in Idaho within and without forest reservations. He seems to have been anxious to confound me upon the statements which I have made from my own personal observations and knowledge. He selects a lot of trifling incidents and localisms that tell nothing in the determination of the great question as to whether or not the Government, after creating the State of Idaho, shall minimize its resources at the instance of nonresident theorists.

It would be interesting to know, after many years of experience under forest-reserve laws, how much timber the Government has sold from such reserves, and how much it has received for it, and what the expenses have been connected with the reservations, and whether the forest conditions have improved under the policy.

I repeat that $I$ am in favor of creating forest reserves at the heari, and only at the head, of streams flowing into arid regions for the purpose of benefiting, if it does benefit, the water supply incident to the irrigation and reclamation of arid lands. For about the first ten years of the application of this law to Idaho, no forest reserve was created at the head of any stream flowing into the arid regions of the State. Such reserves as were created were on the north watersheds of streams flowing into the humid regions of the State. The statements of Mr. Mofitt and Mr. Miller referred to are misapplieá. Neither of those men are in favor of the creation of the Coeur d'Alene Reserve. Fragments of the letters have been used, which letters were written under an entire misapprehension of the proposed extent of the reservation or of the rules governing the same.

Congress has the disposal and control of the public lands of the United States. It delegates it only by statute. It has not delegated the power to any department of the Government to create forest reserves, except for the limited purposes named in the statute, and it expressly excepts lands not valuable for agricultural purposes from the grant of power to create forest reserves. 
Did I not believe that there was a threat of great injury to the State of Idaho in the creation of these forest reserves, I certainly should not urge these objections; but I know whereof I speak, and all of the theories and reasons from the standpoint of those who are seeking to find reasons for tying up these vast areas of the State fall to the ground in the face of practical experience and observationi:

I do not think that I can be charged with a desire to wreck the present or future prospects of Idaho by the destruction of its resources.

I desire distinctly to be understood that I do not approve of the reservations referred to under the head of those approved by me to the extent of such reserves as withdrawn or proposed. I approve of creation of the reserves of a proper size at the headwaters of the Payette, Sawtooth. Lake Henry, and Yellowstone, but there is not the slightest occasion for the creation of reserves at these points aggregating over $5,000,000$ acres of land.

Every acre of the proposed Coeur d'Alene Reserve is within railroad limits, and would result in the creation of "scrip" or exchange right in lien thereof to the railroad. 'The Priest River Reservation is also all within the railroad limits, and represents an issuance of " scrip" for every alternate section.

Mr. Pinchot is mistaken in his conclusion as to the temper of the people in Shoshone County, or in any other mining section of Idaho, in regard to the creation of these reservations.

The people of Idaho are more largely native-born eitizens than those of any other State in the Union. Their educational standard is above the average. Their patriotism is unquestioned. The people of no State in the Union are more trustworthy guardians of the interest of the United States in Idaho as are the people of Idaho.

Forest reserves have been. and are now, being used as the means of perpetrating the grossest frauds upon the Government in securing its public lands through the means of " exchange right" as to the railroad lands and other Government grants.

The timber steal referred to exists because of the incompetency of the Government officials whose duty it is to prevent the crime, but that does not afford a reason for doing an injury to a State or the people thereof by shutting out the settler and home maker.

Give us a little home rule in Idaho in regard to these matters. Give us the benefit of the judgment of intelligent American citizens whose interest in the state. as well as in the Government, is conscientious and capable, and there will be none of this controversy; the Gorermment interests will be protected more fully than they now are. Notwithstanding my frequent protests and direction of the attention of the Government representatives to the devastation of the forests by timber stealers, it has gone on, and it will go on, if the attention of the officers of the Government can be diverted from these important questions to the pursuit of imaginary evils as to what might occur elsewhere but does not.

As requested, I return you herewith the letter from Mr. Pinchot to yourself under date of Jume 12, together with the papers additional thereto.

Sincerely, yours,

W. B. Heyburs. 
Senator Heyburn to the President.

The President,

Wallace, Idaho, August $2 \%, 1904$.

Washington, D. C.:

Mr. Gifford Pinchot, Chief of the Division of Forestry, visited this section recently for the purpose of investigating the sentiment among mining men, prospectors, and residents generally in regard to the creation of a forest reserve covering the Coeur d'Alene mining country. I assume he will report to you the result of his visit. I desire, however, to state it from the standpoint of those interested here. Not only is the sentiment universally against it, but the Republican party and State platform took a broad stand against the withdrawal for forest reserve purposes or the creation of forest reserves, such as that proposed in this section of the State.

Respectfully, yours,

IV. B. Heyburs.

\section{Senator Heyburn to the President.}

The President:

Wasinngton, Warch 30, 1905.

I am advised on inquiry at the General Land (Office that on the 21st day of March, instant, a telegram was sent to the register and receiver of the Coeur d'Alene and Lewiston land offices, in Idaho, directing that townships $42,43,46$, and 47 north, range 2 east; township 44 north, range 3 east, and township 45 north, range 4 east, Boise meridian, were withdrawn from settlement for forest-reserve purposes.

It will be observed that the townships do not form a compact body, but represent selected townships within the timber lands of Idaho, for some of which applications for survey have been made, some of which are under contract for survey, and all of which should be surveyed and open to either selection by the State under its authority, pursuant to its constitution and the act of admission, or to settlement by bona fide settlers.

It looks to me as though this was indirectly using the right to make withdrawal for forest-reserve purposes to prevent settlement, rather than to preserve forests.

I understood at our last interview with reference to forest reserves that no more withdrawals were to be made in Idaho without some conference and concurrence of action on my part.

The accompanying sheet will show you the disconnected area of these withdrawals.

$$
\text { Very truly, yours, }
$$

W. B. Heyburn.

\section{Senator Heyburn to Mr. Barnes.}

$$
\text { W'ashington, April \%, } 1905 .
$$

Dear Sir: Before leaving, the President requested that I submit the matters pertaining to the creation of forest reserves in Idaho to him, and I have formulated the same, which I hand you herewith, 
They are not to be referred to any Department, but at his request are to be forwarded directly to him.
Very truly, yours,
IV. B. HeYburn.

Bendamin F. Barnes, Esq., Assistant Secretny to the President, White House.

\section{Senator Heyburn to the President.}

\section{Washington, A pril 6, 1905 .}

\section{The President:}

Pursuant to our conversation relative to the withdrawal of the proposed Shoshone Forest Reserve in Shoshone County, Idaho, and the statements concerning the reasons for its creation made by the representatives of the General Land Office and the Forestry Department on the evening of March 30 ultimo, at the White House, I desire to suggest that the altitudes within such withdrawal are, except as to the mountain peaks and higher levels of approach thereto, easily within the limits of successful and convenient settlement.

The altitude at Wallace, Idaho, is 2,728 feet. This would apply 10 the valley of the South Fork of the Coeur d'Alene River in a vicinity of several miles extent, the altitude gradually decreasing down said valley to Lake Coeur d'Alene, which has an altitude of about 2,100 feet.

The proposed withdrawal, which lies to the south of the said river, beginning at Wallace, except as to the mountain peaks, which constitute only a small portion of the said proposed withdrawal, has a general elevation of less than 5,000 feet, and there are vast quantities of land within the proposed withdrawal ranging in elevation from 3,500 to 4,000 feet. 'That said elerations are entirely within the range of not only possible, but profitable and comfortable settlement and residence, may be gathered from a comparison with elevations of other extensive areas of settlement within the United States having a much less comfortable climate than the portion of Idaho under consideration.

In Wyoming the vast plains upon which Cheyenne, Laramie, and Rock Creek, and other centers of population are located, are all above (;,000 feet, Cheyenne being 6,105, Laramie City 7,153, Rock Creek 6,708. In Colorado the great plains and wheat fields about Denver have an elevation exceeding 5,000 feet. In the Del Norte Valley the elevation is above 5,000 feet; South Park, Colorado, is above 6,000 feet; the Gunnison Valley is above 7,000 feet; Colorado Springs is above 6,000 feet; Manitou Valley is above 6,000 feet; the San Juan Valley is about 7,000 feet; Greeley is 4,649 feet; the fertile and beautiful valley of Reno, Ner., is 4,500 feet; the Great Carson Valley in Nevada is 4.700 feet; the Ogden Valley in Utah, noted for its fruits, vegetables, and grains, is 4,300 feet; Salt Lake Valley is 4,300 feet.

All of these elevated sections of the country are noted for their production of grains, grasses, fruits, and regetables, and are center:s of population, and which a generation ago were as unforbidding in appearance and promise as the lands proposed to be withdrawn for 
the Shoshone Forest Reserve, and which have only remained unsettled because the population of the country has not yet demanded these waiting opportunities.

This withdrawal is on the headwaters of the North Fork of the Clearwater and the St. Joe rivers and on the south slope of the South Fork of the Coeur d'Alene River. Upon all of these streams, lower down than the proposed reserve, prosperous settlements, towns, and cities now exist, which are every year spreading to the eastward up the streams to their sources, and, as I suggested at our recent interview, if you will leave this country open to settlement and take the census five years from now, it will present as large a percentage of growth in settlement and prosperity as any other section of the country. At the mouth of the Clearwater River, which is only 60 miles downstream from the withdrawal, figs were ripened in the open air along the river during the last season, and the lands along this stream and its tributaries up to the very edge of the reserve produce as fine fruits and regetables as may be found anywhere.

The oldest settlement in Idaho is at the very corner of the proposed reserve-Pierce City-where the first discovery of gold was made in the State, and which produced, according to Mr. Bancroft's reports, $\$ 100,000,000$ from its adjacent gold fields, and which to-day is a prosperous community of men engaged in mining and the raising of grains, regetables, and fruits. Every year sees the settlements push farther up these streams, and there are now prosperous mining camps and growing settlements right in the rery heart of the proposed reserve.

Shoshone County has only recently made provisions for the building of a wagon road up Placer Creek from Wallace, entirely within the proposed withdrawal, which wagon road is to be built for the accommodation of actual business and actual settlements sufficient to satisfy the commissioner's of Shoshone County that the road was needed, a trail having been already constructed from Wallace to the St. Joe River for the purpose of the preliminary accommodation of these settlements.

You will recall that the representative of the Forestry Department stated that a large number of settlements had been found by their representatives to be bogus. Their remresentatives are evidently unacquainted with the methods of settlers. They know nothing of the genesis of the great West. It is so easy to condemn the enterprises of other men and their judgment in entering upon the contract by those who are not in sympathy with them or advised as to what human energy can do.

You will observe that the proposed reserve extends to the towns of Wallace and Mullan. Wallace has a population of about 4,000 people. This reserve will draw a dead line at the very door of that city, and, as shown upon the map which the Department has furnished me, will actually include a part of the corporate limits thereof. It includes the wagon roads already constructed at great expense, mines well developed and producing ores, and rested interests which only await the completion of the system of public surveys to be perfected into titles.

I am making a strenuous effort to extend and complete the public surveys over this very portion of Idaho, in order that the settlers may 
be enabled to acquire title. You will readily understand that until the public lands are surveyed settlers hesitate to cast their lot upon them, not knowing how soon they may be able to perfect their title in the interest of themselves and their families.

Last vear a considerable part of the money set aside for the survey of public lands in Idaho was returned to the Treasury because the survering contracts were not let, and the money was not exhausted. 'This was through a mistaken policy that the surveys should not be extended until after settlement upon each township. The correct rule is that the survey should precede the settler, as an inducement thereto.

I hope to secure such changes in this policy as will place Idaho more nearly upon an equal footing with her sister States. You will be surprised to learn that 55 per cent of the public lands of Idaho are unsurveyed, while in California only 7 per cent remain unsurveyed; in Colorado, 6 per cent; in Wroming, 4 per cent, and in Washington, 11 per cent. It is evident that Idaho is at a disadvantage in the inducement which it can offer to settlers in this particular.

As to the climate of the proposed reserve, there is no more delightful or beneficial climate in the United States. It is within the influence of the Japan currents, which result in long seasons of warm weather. The country is one that needs no irrigation, being within the humid region and with an ample snowfall, which goes off early enough to allow for the cultivation and ripening of crops.

To one unused to that section of the country the land might seem to be sterile and lack those qualities that insure the production of crops, but to those who live there and know the facts the land is as fertile as that of any other section of the United States and responds to cultivation in the most satisfactory manner.

All men do not desire to live on open prairies or in low valleys. There is a fair percentage of the people that prefer to make their homes in the mountains and that know how to make those homes productive and prosperous. The field of choice should be left open to them. The people surrounding this section of the country and who are expecting in part to inhabit it protest against the creation of this forest reserve or any part of it. and they do so, not from a spirit of opposition nor from a desire of opportunity to defraud the Government or violate the law or its intent. but because they want it left open for settlement, which will contribute to the business prosperity of the country, widening its borders and broadening the field for the extension of its enterprises.

The area proposed to be withdrawn constitutes more than half the area of Shoshone County and leaves only a narrow strip of the county on the west, a veraging about 10 miles in width and 60 miles in length. Aside from this strip of land there remains only that portion of the county covered by the Coeur d'Alene mining district to which your order of restoration made during last fall applies.

Already the resources of Shoshone County have been diminished and dwarfed by the withdrawal of November 14, 1903, which has remained without final action. A withdrawal for any purpose is as effectual in keeping out settlers and enterprise as the final creation of a forest reserve.

I append hereto a correct map of Shoshone County, showing the 
propesed withdrawal of land and showing the withdrawal of Novenber 14,1903 . I earnestly request that you take such action as will restore these lands to the public domain.

Mr. President, I do not desire to be understood as opposing the principle of forest reserves, but I do not regard these proposed withdrawals as being within either the spirit or the principle of the law under which forest reserves were intended to be created. It was not intended that they should be used to exploit a theory at the expense of the State, nor was it intended that they should be created against the protest of the people most interested in the growth and development of the State. I know this country; I have lived immediately on its borders for more than twenty-one years. I have traversed much of it, and I should regard it as a calamity to the county and to the State and as unfair to the people who have now or who in the future would have homes and enterprises within Shoshone County.

The proposed withdrawal for the Shoshone Forest Reserve amounts to more than 1,000,000 acres, and the eleven townships examined for withdrawal and shown on the map in yellow amount to 253,440 acres. The six townships withdrawn Norember 14, 1903, amount to $138,2+0$ acres, making in the aggregate more than $1,000,000$ acres of land withdrawn in Shoshone County.

Since the enactment of the law at the last session of Congress preventing the location of lieu land scrip upon timber lands, which was a threat against the splendid areas of timber contained within this proposed withdrawal, the threatened danger of corrupt practice in the securing of timber lands no longer exists, and it would be a humiliating admission of incompetency for the Land Department to plead that it was unable to prevent fraud in the entry and settlement of these lands. The existing laws contain no threat against the integrity of the public-land system, and because a few or many individuals have perpetrated or are seeking to perpetrate frauds in securing public lands constitutes no reason why that great system, which has been so beneficial to us in effecting the great empire of the West, should be suspended or repealed.

s It is too often the case that a new generation, lacking the experience and energy resulting from actual contact with conditions, condemns the work of their forefathers and forerumners. No srstem regarding the public lands which has resulted within our time in creating the great empire lying west of the Mississippi River should be condemned because combinations of capital and corrupt individuals seek to circumvent and avoid the legal restrictions intender to secure a fair and equitable distribution of the benefits of the public domain among all classes of citizens. It would be better that these lands be open to settlement even though it were found necessary to send an agent of the Department to examine every homestead before final entry was made.

We were made a State and told to grow. We were endowed with generous donations of public land for public purposes to stimulate and foster the growth of the State. The public lands of the United States within the State were a part of its assets upon which its growth should rest. While they are the public lands of the United States they are available only to those who go within the State, and 5245-No. $67-05$ «- 3 
those who are living beyond the borders of the State have only a sentimental and contingent interest in the disposal of these lands. The first consideration is to the citizens of the State. They are above the average American citizenship, as shown by the census. A larger percentage of the citizens of Idaho own their homes than in most any State in the Union. The family life in Idaho is shown to be above the average standard. The percentage of American blood in Idaho is greater than that of the New England States. The laws of the land are respected in Idaho to as great an extent and with as fervid a patriotism as in any State of the Union. Railroads are being constructed as rapidly as in any other State. Great irrigation and reclamation projects are being pressed in southern Idaho upon a plan that promises a growth that equals, if not exceeds, that of any other State in the immediate future. North Idaho has vast wheat fields and produces all the fruits of the market. Shoshone County produces more than half the lead product of the United States. She produces millions of dollars in gold and silver. She has the finest white pine timber lands now remaining in the United States. It is intersected by splendid rivers and their tributaries to its very borders on the east.

There is another proposed forest reserve, called an addition to the Bitter Root Forest Reserve, which is shown in green upon the accompanying map. It includes the town of Newsome, a place of considerable business importance. which has existed for at least forty vears. I have risited this place mrself. There are prosperous commercial institutions there-hotels. residences, gardens, orchards, meadows, farms. and mining. The town of Florence, shown within the proposed addition to the Bitter Root Forest Reserve, is the second oldest town in Idaho. It is the center of a mining region, but is surrounded by the class of homes incident to such countries where they have orchards and raise all sorts of garden truck to supply the miners. and graze or farm as the land may be adapted to those purposes. The State wagon road of Idaho traverses this reserve for many miles. This road was built at an expense of over $\$ 300.000$ by the State for the purpose of enabling the people to get into this very country, because it was a promising and profitable field for settlers, and now it is proposed to withdraw the very country from settlement that the State was at such heary expense to open for that purpose. It extends almost to the banks of the Little Salmon River, down which is survered a line of railroad now under construction. and it proposes to tie up the country that was intended to feed that railroad for $\check{0} 0$ miles or more.

Mr. President, give Idaho a chance to grow; leave the door open to settlement, and trust somewhat to the integrity, loyalty, and patriotism of the citizens of the State.

I most respectfully ask that you shall take such action as will restore the lands withdrawn and proposed to be withdrawn to settlement and induce rather than discourage the home seeker to come to Idaho.

Respectfully submitter, 


\section{Mr. Loeb to Mr. Pinchot.}

\section{Washington, March 31, 1905.}

Mr De.sr Mr. Pinchot: The President would be glad to have you send him a report on the matter referred to in the inclosed letter from Senator Heyburn, dated the 30 th instant.
Very truly, yours,
Wir. Loeb, Jr., Secretary to the President.

Mr. Gifford Pinchot,

Department of Agriculture.

Mr. Pinchot to the President.

The President,

Wasmingtox, A pril 10, 1905.

White House.

Dear Mr. President: On my return to Washington I am glad to report on the matter referred to in Senator Heyburn's letter to you of March 30, as requested in Mr. Loeb's letter of March 31.

The object of the temporary withdrawal of lands in Shoshone County, Idaho (which is the action objected to by Senator Heyburn), was discussed on March 31 in a conversation between yourself, Senator Heyburn, Mr. Fimple, and Mr. Price, and I need now only repeat the statements then made by Mr. Price. His views entirely coincide with my own.

The lands in question adjoin the present Bitter Root Forest Reserve on the north, include approximately 1,150,000 acres, and were temporarily withdrawn from settlement by the Secretary of the Interior on March 21, 1905, in accordance with the recommendation of the Secretary of Agriculture, on my advice. This action was based on the results of a detailed field examination made last summer by one of our men. The lands were shown to be well suited to forest-reserve purposes, and the withdrawal was recommended because otherwise title to much of the best timber land would soon pass into speculative hands unless immediate action was taken.

Senator Heyburn's chief points of objection appear to be as follows:

(1) That the withdrawal does not form a compact body, but is made up of scattered townships, for some of which surveys have been made or are now under way.

The Senator is evidently misinformed as to the location and extent of the withdrawal, for, as a matter of fact, it forms an absolutely compact area, which may be readily seen from a glance at the inclosed map. It is true that several of the townships have been surveyed or are now being surveyed, but this forms no objection whatever to the withdrawal, as is explained below.

(2) That the withdrawal was made rather to prevent settlement than to preserve timber.

If the lands are agricultural in nature, Senator Heyburn has good reason to object on this score; if the lands are not agricultural, no settlement is possible, and this objection does not hold. 
The whole region has been carefully examined and mapped by the forest service and is shown to be a rough, mountainous country broken by deep precipitous canyons, almost wholly without alluvial bottom lands. The only open lands are on the ridges at altitudes of from 5.000 to 7,000 feet above sea level. where successful cultivation is naturally impossible. Approximately 90 per cent of the area of the withdrawal is timber land which has been burned over, and the remaining 10 per cent is merchantable timber land which has not as ret been injured by fire and which will a verage 20.000 board feet to the acre. The principal trees are white cerlar, white pine, and tamarack.

From the field map, which shows the character of land in each section, there are shown to be no bodies of agricultural land whatever within the area withdrawn.

A survey of four townships, townships 46 and 47 north, range 5 east, and township 47 north, ranges 4 and 6 east, has recently been completed. The temporary withdrawal of these particular townships is specifically objected to by Senator Heyburn on the ground that settlement is prevented. The report shows that in these four townships there are approximately 90 squatter's claims, of 160 acres each, all of which are located on the rery best of the timber lands, and on none of which the slightest pretense of cultivation has been made. On most of the claims are cabins representing a cost of from $\$ 6$ to $\$ 10$. The claimants can have no intention of making agricultural settlements and are endeavoring to gain possession of the land for its timber only. As soon as they have obtained title. they will undoubtedly sell to the highest bidder.

In brief, according to our in formation, the whole area is good forestreserve land and is totally unfitted for agricultural purposes. If this proposed reserve is eventually created. its chief object will be, of course, to protect and wisely use the timber resources for the best permanent good of all the people, with special regard to the future prosperity of the mining interests. The general policy of the Govermment in establishing forest reserves has already been thoroughly discussed with Senator' Heyburn and need not again be referred to.

(3) That the State of Idaho should not be prevented from making selections within this area.

Senator Heyburn apparently assumes that the State will lose its right to school sections on lands the surveys for which have not been approved. As a matter of fact, the State of Idaho will not lose these lands, even if the proposed reserve is eventually established before survers have been approved. A decision to this effect was made by the Secretary of the Interior on May 21, 1904. The State, however. will naturaliy lose its right of lieu selection within this area if the temporary withdrawal is eventually made permanent. This loss will not be a serious one, because there are large areas of valuable lands to choose from in other localities.

The memorial recently passed by the lower house of the Idaho State legislature tends to show that the State looks favorably upon the creation of additional forest reserves. This memorial, addressed to the President and the Secretary of the Interior. requests that new reserves be established in Idaho for the benefit of the agricultural, mining, and lumbering interests. 
(4) That it was agreed that Senator Heyburn was to be consulted before temporary withdrawals were made.

I do not remember that any such agreement was made. On the contrary, it was distinctly stated at the time that withdrawals would have to be made before consultation with anyone, in order to prevent the possibility of locations within proposed reserves for speculative purposes. The understanding was that no action would be taken on the final creation of several proposed reserves in Idaho until Senator Heyburn had been notified, and these reserves were mentioned in my letter to you of June 12, 1904. It was never agreed that the Senator should be consulted about temporary withdrawals of land.

Senator Heyburn's letter is returned herewith.

Very sincerely, yours,

Gifrond Pinchot, Forester.

Mr. Pinchot to Senator Heyburn.

Wasmington, A pril 1\%, 1905.

DeAR SIR: In accordance with the plan agreed upon in our conversation with Mr. Fimple. I am glad to give you a list of those proposed forest reserves in the State of Idaho which, on my recommendation, are now submitted to the Department of the Interior for final establishment:

(1) Henrys Lake.

(2) Addition to the Yellowstone.

(3) Sawtooth.

(4) Payette.

(5) Addition to the Bitter Root.

(6) Squaw Creek division of the Weiser.

A State map of Idaho is inclosed upon which is indicated the location and extent of each proposed reserve and addition.

In accordance with our understanding, the drafts of proclamations for these reserves will be held by the Commissioner of the General Land Office until he is in receipt of any protests you may wish to file against their creation, but they will not be held for a period longer than thirty days from the date of this letter. On the receipt of your protests they will be attached to the drafts of proclamations and submitted to the President through the honorable the Secretary of the Interior.

Very truly, yours,

Gifford Pinchot, Forester.

Hon. IT. B. Heyburs,

United States Senate, Washington, D. C.

Mr. Pinchot to the Acting Commissioner of the General Land Office.

Wasmington, A prit 1\%, 1905.

Dear Sir: I am glad to inclose for your information a copy of a letter which I have to-day addressed to Senator Heyburn. This is in accordance with the agreement reached in our conversation of 
April 11. The understanding is that the final drafts of proclamations for these proposed reserves and additions will be held in your office until Senator Heyburn's protests are received, but for a period not longer than thirty days from the date of this letter. His protests will then be attached to the proclamations and submitted to the President through the honorable the Secretary of the Interior.

Very truly, yours,

Gifford Pinchot, Forester.

The Acting Commissioner, General Land Office.

\section{Senator Heyburn to Mr. Pinchot.}

Wasmingtos, April 19, 1905.

DeAr Sir: Will you kindly furnish me memorandum of all areas of land in Idaho which you contemplate withdrawing for forest reserve purposes upon which final action has not been taken. Also a memorandum of all areas already withdrawn for forest reserve purposes. If you could show these under their separate heads upon a plat it would aid me very materially in disposing of the public interests concerning these matters.

Very truly, yours,

Gifford Pinchot, Esq.,

IV. B. HeYburn.

Chief, Bureau of Forestry, Department of Agriculture.

Senator Heyburn to Mr. Pinchot.

Wasmington, 1 pril $22,1905$.

Dear Sir: Yours of April 12 and accompanying map of Idaho showing the proposed forest reserves and additions now under recommendation from you to the Department of the Interior for final establishment is received, and I have this day filed objections to a portion of the proposed reserves, as indicated by the letter, of which I inclose you a copy herewith.

Very truly, yours,

Mr. Gifford Pincilot,

IV. B. Heyburn.

Chief, Burean of Forestry, Department of Agriculture.

Senator Heyburn to the Commissioner of the General Land Office.

Washington, 1 pril $21,1905$.

DEAR SIR: I desire to enter a protest against the proposed reservations, as follows:

HENRYS LAKE RESERVE.

Against all that part of the Henry's Lake Reservation covering Beaver and Spencer stations and the adjacent country, and to all that 
part lying south of the standard parallel and extending eastward into the Yellowstone National Park.

The reason for my objection to this is that the growing towns along the railroads should not be included within a reservation. That the reservation south of the standard parallel and extending to the National Park amounts simply to an enlargement of the Yellowstone Park in Idaho without carrying with it the privileges of the park. and practically shuts off entry from Idaho into the National Park over its own border. Much of the lands included within this proposed reserve are not timber lands at all, and never will be. An examination that would result in reporting them as fit for timber reserves must have been made either at a great distance or very superficially. They are largely grazing lands.

\section{SAWTOOTI RESERTE ADDITION.}

Mr objections to the Sawtooth addition are based upon the fact that it includes the town of. Banner, which is a prosperous and growing community, and that its growth would be stopped by the creation of a forest reserve over it. That it also includes the town of Itlanta, which is one of the oldest towns in the State, and in which millions of lollars are invested in mining and kindred enterprises; which after a long period of stagnation incident to the financial reverses of a few rears ago has just started on a new growth with renewed energy. That it also includes Rockybar. notwithstanding that a narrow strip has been omitted along the road from Mountainhome into that town. This is one of the oldest towns and sections in the State. and the setthements are spreading every rear in every direction from this center. It also includes the new settlements of Edna and Sartooth, and crowds close down to Pioneerville, one of the oldest mining towns in the Boise Basin. As I suggested in a personal interview with you in regard to this matter, a timber reserve might be safely created running along the watershed to the northeast of Banner. The towns I have mentioned have schools. churches, homes, and permanent settlements which would be rendered comparatively useless by the creation of such reserve. This reserve should be confined to the mountains above the settlements and towns. It also includes Twin Springs; which is at the head of the Boise Valley and near Boise Basin.

\section{PAYETTE ADDITION.}

With reference to the Parette addition, my objections are based upon the fact that it includes a vast quantity of land upon which there is no timber. It also includes the town of Warren, a settlement since 1862 , round and about which are some of the best mines in the State of Idlaho. This reserve has evidently been selected without any personal knowledge on the part of the selector of the conditions upon the ground in this section. It covers a considerable portion of the State wagon road constructed by the State to enable settlers to get into this very country. This reserve cuts off the Thunder Mountain mining country from the north by a barrier which amounts to a prolibition against those who desire to operate these mines from that direction, and they are easier of access from the north than from anywhere else. The reservation covers a large amount of mining 
country, now being taken up and settled, about and adjacent to the Thunder Mountain district. To withdraw it is to paralyze the rapid growth now going on in that section of the country.

The map furnished me does not indicate the fact with certainty. but I believe the proposed reserve covers the Thunder Mountain mining district and the town of Rooserelt, which is one of the most rapid-growing and prosperous new places in Idaho. There are sereral thousand people in that section of the State, who went there with the intention of staying, provided they could have the rights of settlers in other sections of the country without being “- supervised."

BITTER ROOT ADDITION.

As to the addition to the Bitter Root Reserre. which includes the towns of Newsome and Florence. there is absolutely nothing to be said in favor of it. Like the Bitter Root Forest Reserve it is at the head of streams flowing into regions where irrigation is not needed and where the complaint is " too much water " rather than not enough. The town of Florence, which was settled in 1862. and which with its immediate surroundings has produced over $\$ 100,000,000$ in gold. is still a flourishing and producing country, and is built up with schools. churches public institutions, and homes. A statement of these facts should in itself be sufficient to malie the consideration of the creation of a forest reserve impossible.

I have already discussed the town of Newsome in a former protest: it is a growing and prosperous town on the state wagon roarl. The country lying between these two points contains some timber, but it is worth infinitely more for home making and agricultural purposes.

\section{SQTAW (REEK DIVISION OF WEISER RESERTE.}

The Squaw Creek division of the Teiser Reserve has some merit. provided that Garden Valley, at the lower end of it, is omitted, and townships 17 north. ranges 1 east and 2 east. and townships 18.1 east. are eliminated. inamuch as a line of railroad is now actually constructed to Council. and is under contract for an extension over these very lands.

IIr. Pinchot has furnished me with a map showing these proposed reserves. and I presume that you also have a map of the same kinrl. Should such not be the case you will please advise me and I will have the map furnished me handed to your.

I am sending this communication to you under the statement from Mr. Pinchot that the same will be forwarded by you to the Secretary of the Interior. and by the Secretary of the Interior to the President. as I intend that my protest shall reach the President before any further action is taken in regard to this matter. I also understand that no further orders in regard to the creation of forest reserves as mentioned herein, or withdrawals for forest reserves, will be made until after any protest which I have filed shall have been reached and considered by the President.

Very truly, your.

Hon. IV. A. Richards,

W. B. Heyburs.

Commissioner of the General Land Office. 


\section{Mr. Pinchot to Senator Heyburn.}

\section{Wasmington, A pril 24, 1905.}

Dear SIR: Upon my return to the office vour letter of April 19 has been brought to my attention. Within a few days I shall be glad to send you a map of Idaho showing the lands temporarily withdrawn from settlement for proposed forest reserves. As I have already explained to you, I am not in a position to give you information in regard to any additional areas which may hereafter be temporarily withdrawn.

$$
\text { Very truly, yours, }
$$

Gifford Pinchot,

Forester.

Hon. W. B. Herburn,

United States Senate. Washington. D. C.

Mr. Pinchot to Senator Heyburn.

Wasimangton, 1 pril 25, 190.5.

Dear SIR: I am in receipt of your letter of A pril 22. transmitting a copy of the objections you have filed with the Honorable the Secretary of the Interior to the proposed forest reserves in Ilaho for which proclamations have been prepared.

$$
\text { Very truly, your's, }
$$

Giffori Pinchot,

Forester.

Hon. IV. B. Heyburs.

United States Senate, Washington, D.C.

Mr. Pinchot to Senator Heyburn.

Whishomgon, May 4, 1905.

DEAR SIR: Upon looking over the map of Idaho of which I gave you a copy with the proposed new forest reserves outlined, I find that errors in the location of towns are responsible for most of your protests against these reserves. The outlines of the reserves were drawn as they are recommended, but the draftsman did not alter any features printed on the original map.

If you will examine the map again you will find two towns of Newsome. The one shown in the proposed addition to the Bitter Root has no actual existence. Garden Valley, shown to be just within the proposed Squaw Creek division of the IVeiser, is in reality several miles outside, to the east. Sawtooth, Twin Spring, and Rockybar are all excluded from the Sawtooth, although their erroneous location indicates otherwise. Spencer is not in the Lake Henry area. Roosevelt is 20 miles from the proposed boundary of the Payette. ${ }^{a}$

These towns were located by the examiners as accurately as possible from more recent and reliable maps and plats, and the boundaries are recommended so as to exclude them. In unsurreyed regions it is obviously necessary to locate lines by projecting them from the nearest surveys. It is hardly likely that any offsets in future actual surveys

$a$ The map and diagrams showing the exact and the erroneous locations of the towns named will be found at the end of this bulletin. 
will result in the failure of our prescribed. boundaries to effect the desired exclusion, but if they should do so in any case prompt correction will be made.

Since the supposed inclusion of these towns constitutes nearly all your stated grounds of objection, as I understand them, I presume your protests will be withdrawn or greatly modified upon this explanation. Perhaps we can agree in certain reserves as a result.

Very truly, yours,

Gifford Pinchot, Forester.

Hon. IV. B. Heyburs, Wallace, Idaho.

Senator Dubois to the President.

Wasmington, D. C., May 5, 1905.

The President :

I propose to discuss the question of the establishment. of forest reserves by the National Government, directing my attention especially to the proposed new reserves in Idaho.

I am a strong adrocate of the policy of forest reserves, and specifically indorse the National Administration in its proposed reserves in our State. I do this after very careful consideration of all the interests involved. In taking this position I differ radically with my colleague, Senator Heyburn, who objects specifically to the establishment of each one of the proposed forest reserves in Idaho. I understand from the Bonners Ferry Herald and other publications in Idaho that Congressman French and Governor Gooding indorse the position taken by Senator Heyburn. Assuming this to be true, I differ radically with Congressman French and Governor Gooding also.

When forest reserves were first created and that policy first entered upon, and especially during the administration of President Cleveland, the western Representatives in Congress bitterly assailed the creation of these reserves. I joined with my colleagues from the Rocky Mountain region in this opposition, and we continued the fight almost unitedly and with great earnestness for a number of years. Tre disclaimed always any objection to the policy, but contended against the methods which were used in creating, maintaining, and controlling these reserves. During those years reserves were created without sufficient investigation, and there were not sufficient safeguards to protect stock raisers, miners, lumbermen, agriculturists, and people of our section generally. The fight of the western men was constant and united. Our demands were set forth in numerous speeches and finally were acceded to. The policy which controls the creation of forest reserves to-day and their administration is substantially the policy which the Representatives of the Western States in Congress have contended for, and is substantially what the West, through its Representatives, demanded.

The passage of the national irrigation act and the construction of large irrigation works by the Government all over our western country, which will reclaim millions of acres of desert land, has made the further extension of forest reserves already existing and the creation 
of new forest reserves a necessity. Forest reserves and irrigation go hand in hand. You can not separate one from the other.

The trouble with my colleague, Senator Heyburn, is, I think, that he is making a fight based upon conditions which do not now exist. He is contending against evils which the united efforts of the western Representatives in Congress successfully combated and removed before he became a Senator.

If in any proposed reserve anywhere any particular individual or a few individuals suffer, adequate compensation is made to them. All that any such individual or class of individuals has to do is to call the attention of their Congressman or Senator to the facts in his individual case and the proper remedy and relief will be afforded.

The administration of the forest reserves and irrigation under President Roosevelt and his very able administrative officers, Gifford Pinchot and F. H. Newell, desire as much as do the Representatives of our Western States to protect, build up, and in every way advance the material interests of our section, not only for the present but for the future. This fact has been fully demonstrated, and in consequence, in my judgment. it is the duty of our Representatives from the IVest in Congress to sustain the Administration in its fair, just, and liberal policy toward the far IVest. There are plenty of eastern and middle west Representatives in Congress who seek an opportunity to find fault with the great development which is now going on and which will continue to increase in our section. Generally speaking, however, the balance of the Representatives look with complacency on the expenditure of millions and millions of dollars for the reclamation of the West, and there is nothing like an organized opposition to oppose the expenditure of these large sums of money in our section. Our own Representatives should be very careful, it seems to me, not to encourage or give excuse for any such opposition unless their reasons for so doing are absolutely sound and tenable.

Senator Heyburn has made specific objections to each of the proposed reserves in Idaho, or indicated that he will do so. I must assume that he is opposed to the general policy of forest reserves unless they are created and governed under such circumscribed rule; and regulations as will make them ineffective for the purposes sought.

Seren proposed new forest reserves in Idaho have been recommended by Forester Gifford Pinchot to the Secretary of the Interior for final establishment, as follows:

(1) Henrys Lake.

(2) Addition to the Yellowstone.

(3) Sawtooth.

(4) Payette.

(5) Addition to the Bitter Root.

(6) Squaw Creek division of the Weiser.

( 7 ) Cassia.

I will take these up in their order, describing them and adrocating them.

As Congressman French and Governor Gooding have not gone on record specifically in their objections I will not include them in my criticism, unless they indorse the position of Senator Heyburn.

In order that I shall not do my colleague any injustice, and in order that I may be certain that $\dot{I}$ do not misrepresent him, I will 
quote literally his objections. which objections he has cansed to be published very generally and to become his official objections.

\section{THE PROPOSED LAKE HEXRY FOREST RESERTE.}

The proposed Henrys Lake Reserve is in the northwestern part of Fremont County, south of Montana, and on the eastern edge of the Tellowstone National Park. It contains about 75.2.320 acres, 52.000 of which are withdrawn. I am particularly familiar with this entire section, having gone over it many, many times. The area embraced is mountainous and rough, consisting of a narrow strip along the upper southern slope of the Continental Divide between Idaho and IIontana, in which rises Camas Creek, an important irrigation stream. and a projection southerly in the mountains bordering the national park to afford protection to the North. or Henrys. Fork of Snake River. The valley of this stream contains the only cultivable land within the proposed boundaries, and most of this is exchuded from the reserve, as the area adjoining and south of Henrys Lake is to be exempt. There are only about 6.000 acres of agricultural land in the entire reserve. This has been practically taken up, and the creation of the reserve will not prevent its use or occupation by its present owners. The entire region supports no industries but grazing, except, as I have indicated, farming along streams. The timbered land comprises forests of inferior lodge-pole pine. with occasional bodies of red fir. They are not raluable for lumber. but are exceedingly raluable to protect the very important streams which I have mentioned. which go to form the headwaters of the Snake River. Whatever supply of merchantable timber there is should be carefully guarded. as it will all be needed in that section. There is constant danger from fire and overgrazing, and the importance of the streams for irrigation makes immediate protection rery desirable. $\mathbf{A l l}$ of the water in this part of Idaho is utilized. and there is no possibility for increasing the acreage except by irrigation. The North Fork of Snake River already waters about 230.000 acres of land south of the proposed reserve in Fremont County, and the Reclamation Service has surreyed and planned several reservoirs, the creation of which will be of great benefit in the reclamation of arid lands. The success of these reservoirs depends largely on forest protection. Sheep and cattle from all over southeastern Idaho and from adjoining States contend for this grazing country, with the result that it is overstocked and the ranges and water flow suffer in consequence. No local interests will be disturbed, and those who are living on the proposed reserve are anxious for relief and from grazing competition. I suppose the large sheep owners in southeastern Idaho, who disapprove of all forest reserves because they have a tendency to restrict their privileges. object to this particular reserve. If they are residents of the region proposed to be reserved, they $w$ ill be protected and the gainers, as they will be the first who are allowed to take permits for grazing. It is the policy of the Administration everywhere and at all times to permit a reasonable amount of grazing.

The greatest irrigation project which will be undertaken anywhere in the United States, in my judgment, will be the one which contemplates the storing of the headwaters of the Snake River. Jacksons Lake will be made into a great reservoir. into which will be emptied 
the waters of Emma Matilda and the Twin Ocean lakes. Reservoirs also will be built around the Henrys Lake country, and the storage aapacity of these various reservoirs will suffice to reclaim from $1.500,000$ to $2,000,000$ acres of new land. none of which can be cultivated with the existing water supply. In addition to this, the building of these great reservoirs and the conservation of the flood waters will make sure the adequate supply of water for the lands in the Sinake River Valley which are already under cultivation. The protection of forests is one of the very great factors in this great development.

I quote now Senator Heyburn's protest against Henrys Lake Reserve. In all my quotations from Senator Heyburn's protest I use his exact language.

The Senator protests-

Against all that part of the Henrys Lake Reservation covering Bearer and spencer stations and the adjacent country, and to all that part lying south of the standard parallel and extending eastward into the Yellowstone National Park.

The reason for my objection to this is that the growing towns along the rail. roads should not be included within a reservation. That the reservation south of the standard parallel and extending to the national park amounts simply to an enlargement of the Yellowstone Park, in Idaho, without carrying with it the privileges of the park, and practically shuts off entry from Idaho into the national park over its own border. Iuch of the lands included within this proposed reserve are not timber lands at all and never will be. An examination that would result in reporting them as fit for timber reserves must have been made either at a great distance or very superficially. They are largely grazing lands.

In his protest against this reserve Senator Heyburn has absolutely ignored facts. He assumes something which does not exist at all and then objects to his own supposition. I am surprised that in all the protests which my colleague has made he has been so utterly oblivious to or careless of facts.

Beaver is on the Utah Northern Railroad, a few miles above Spencer. Beaver never was much of a town and never could be, but what there was of it moved to Spencer some vears ago, until now there are but two or three families living there and about one-half dozen empty houses. It is abandoned and abandoned for all times to come. Spencer is a bright little place. It has a hotel, a good-sized store, a saloon, and a few houses. I doubt if Spencer will ever grow much, because there is no good agricultural country near it. However, Spencer is not in the proposed reserve at all.

How the part south of the standard parallel (presumably the third, although not specified) will "shut off entry from Idaho into the mational park " is not easy to see, for not a road or trail crosses this mountainous strip, which contributes largely to the water supply of the Henrys Fork of snake River. In addition, while it is not to be expected that there will be any road building over this mountainous strip, the existence of a reserve would not in any way affect such road building. Senator Heyburn should have known that every privilege of a national park is allowed in a forest reserve, besides very many more privileges.

As I have stated above, this reserve, as proposed, protects Beaver Creek, Camas Creek, and Henrys Fork of Snake River, and any restriction of its area will endanger the irrigation from these streams. 
TIE PKOPOSED IDAIIO ADDITION TO THE YELLOWSTONE FOREST RESERVE.

I am quite familiar also with this country, which is near my home. It contains $17+, 720$ acres, which embraces the forested portion of the Snake River Range, in Fremont and Bingham counties between the valleys of the Teton River and the South Fork of the Snake. It is unsurveyed. and is from 7,000 to 13,500 feet above sea level, and of absolutely no value but for the pasture timber. and water supply which it furnishes the surrounding arid but fertile plains and valleys.

The only cultivable land is a tract of 51 acres corered by an unimproved claim. Grazing and irrigation farming are practically the only industries of this part of Idaho. Teton Basin on the north of the proposed addition, and Swan Valley on the south, contain agricultural settlements entirely dependent upon it for timber. and they use practically all the water rising therein. except that which during flood seasons finds its way to the Snake and becomes of value farther south. The object of the proposed addition is to protect these districts from the injury to their water range and timber supply, which, through fire and excessive orergrazing by alien sheep, has already assumed alarming propositions.

Remote from market, the residents of the region dispose of their irrigated crops largely by winter feeding of eattle: therefore the destruction of both summer range and water supply constitutes a double and ruinous attack on their present welfare, besides preventing future development. Fire and sheep have alrearly destroyed the forests on the northern end of the Snake River Range so apparently bevond redemption that this portion of the area petitioner for is not included by the recommendations. The necessity of preserving the remainder from such permanent injury is mogent.

Since to do this will require the total exclusion of sheep from about half the proposed addition, and a reduction to about half the number now occupying the remainder. opposition from the sheep interest is inevitable, but the petition for the reserve to the Department of the Interior by 169 residents of the region, dated July 6,1903 , represents the unanimous local sentiment. and asserts that. aside from the irrigation question, unless reproduction is protected the available local wood supply will not last more than fifteen years.

I do not recall having seen any protest from Senator Heyburn against this proposed addition to the Yellowstone Reservation. If he has made such a protest, giving reasons, it has not ret been filed and become official.

THE PROPOSED SAWTOOTH FOREST REFERIE.

The total area which is recommended for this reserve is $1,918,480$ acres. Of this, 13,040 acres have passed wholly or in part to private owners, as follows: (1) Homestead entries, 1,200 acres; (2) timber and stone entries, 2,240 acres, and (3) school lands, 9,600 acres. This is exclusive of mineral lands.

The above entries, almost without exception, have been made along rivers and streams where there are lands that can be irrigated, or in easily accessible bodies of timber. The larger part of the area of this reserve forms much of eastern Boise and northern Elmore counties, with a narrow strip in western. Blaine and Custer counties and southern Idaho County. 
Practically all of the headwaters of the Middle and South Payette rivers and their tributaries, and the North and Middle Boise rivers, with a small portion of the headwaters of the South Boise and TVood rivers, is included.

The proposed area for reservation is rough, and ranges in altitude from 4,000 feet in the lower valleys on the west to over 10.500 feet in the main range of the Sawtooth. There are two main watersheds within the proposed boundaries. On the east side of the mountains a narrow strip makes up a portion of the headwaters of the Middle and South Forks of the Salmon River, which flows northward and eastward to the Snake River. Within this area lie the sereral lakes known as the "Redfish Lakes." From the standpoint of irrigation the waters from this watershed are of no value, as they are not used at any point for irrigation purposes.

On the western slope of the mountains several streams have their rise, which are very important because of the large areas along their lower courses irrigated by their waters. To the northward several important tributaries of the North Pavette River have their source. In the southern portion almost the entire basins of the Middle and South Payette rivers are included, while in the central and extreme sonthern parts all of the basins of the Middle and North Boise rivers above their juncture and a large part of the headwaters of the South Boise River. Of the entire area approximately 36 per cent is drained by the several forks of the Pavette River, and 58 per cent by the Boise and its tributaries. These streams are used within the proposed reserve only for placer mining.

There is a great variety of the pine tree. and the forests of the Sawtooth region can be classified under more than twenty heads, besides such trees and shrubs as cottonwood, alder, willow, birch, hawthorne, and plum. The really important commercial tree of this region, however, is the bull pine, and immense quantities of it have been cut for timber, fuel, and for the derelopment of the mining industry. The trees are often from 4 to 6 feet in diameter and from io to 90 feet in height. They grow at an altitude from 4.000 to 7.000 feet.

Because of the ralue of bull pine for lumber. ties, and mining timbers, much of the best growth accessible to Boise, Idaho City, and smaller towns has been removed. From 3 to 4 per cent of the entire area of the proposed reserve has been removed of its timber to supply the towns and mining camps. Reproduction of the bull pine is entirely feasible in regions protected from fire and sheep. Such protection will be given under the management of a reserve. There can be no assurance of a reproduction and future supply of timber so much needed for the proper development of the mining and agricultural industries if this section is left in its present condition.

The lands in this reserve can be classified as follows:

Acres.

Commercial forest

1. $315,3 S 0$

Woodland (second-growth worthless or stunted species)

$354,661)$

Cut-over -forests

S.5, 298

Burned over

30,160

1,690

Brush land

20,560

Open parks

48. 440

Cultivated land

2, 320 
The species of tree fit for commercial uses are bull pine, lodgepole pine, red fir, Engelmann spruce, and blue spruce.

Open parks comprise only about 1 per cent of the area of the proposed reserve. These are almost altogether in the narrow strip of land east of the main Sawtooth Range and bordering on the Stanley Basin country. The purpose of including these parks in the reserve was to furnish sufficient grazing ground for the animals of campers and pleasure seekers about the Redfish lakes. and to prevent sheep from coming uncontrolled around the lakes and polluting the immediate shores. A few open parks occur in the northern part. as parts of Bear Valley and Deadwood Basin.

Mining is the most important industry within the proposed reserve. Because of the high elevation there can nerer be extensive agricultural development, and in consequence irrigation and water supply can not be rital questions, as ther are at the present time on the lower portions of the river to the south and west of the contemplated reserve. The protection of the watersheds to the east and north of them is of the greatest importance to these rich irrigated regions. Already the destruction of the timber on the hills and valleys by lumbering. fires, and grazing has caused a decrease in the amount of the average annual flow of the streams through the summer. This decrease is being most injuriously felt along the lower Boise and Payette rivers, and unless some protection is given to the water-heds very soon great loss will result to the irrigation interests. If the snow can be retained in the hills until late in summer, through the presence of a forest cover, and the snow water given off slowly to the springs and streams, the rivers will retain an even flow and proper supplies can be obtained for irrigation purposes. Only through a forest cover can these permanent conditions of water sipply be maintained. In a few cases water from the rivers and creeks is being used for placer-mining work, but this is limited to the immediate valleys and does not tend to decrease the total flow of the streams. It was not contemplated that the use of water for placer-mining work shall be interfered with.

There are a few settlements and squatters claims. and these are confined largely to level flats along the streams and rivers. Only twotenths of 1 per cent, or 1.200 acres, have been entered as homesteads, and these are still pending final proof. Many attempts at farming have been made in different parts of this proposed reserve. but so unsuccessful that eren if the reserve should not be made and the land should be left open for homestead entry, very few, if any, of such claims will be taken. There are no incorporated cities or villages in the entire area of the proposed reserve, and but one post-office and that at Atlanta. The proposed area lies very largely in Boise, Elmore, and Blaine counties, there being but small strips of territory in Idaho and Custer counties. The population of Boise County is very largely in the towns of Lardo. Roseberry. Center. Crawford. Tanwyck, Sweet, Idaho Citr, Placerville, and Centerville, none of which towns are within the boundary of the proposed reserve. A very large portion of the population of Elmore County live at Rockybar, Mountainhome, Glenns Ferry, and the towns along Snake River, all of which are south of the reserve. The population of Blaine County is at Bellerme. Hailer, Ketchum, and the towns southward along the railroad. In Idaho County there are no settlements 
within the proposed reserve, and the same is true of Custer County. It is safe to say that there is not more than one person for every 5.000 acres, of the present population on the proposed reserve, and these settlers mostly live in mining camps.

Boise City is the only important town tributary to the Sawtooth region, and it is 15 miles from the proposed boundary. One good wagon road, known as the "State road," crosses the main area from Idaho City on the west to Bear Valley on the northeast. Boise, to the southwest, and Hailey, to the southeast, are the nearest railroad points. Both of these towns are within 20 miles of the lower corners of the proposed reserve. Another good stage road rums in from the south through Rockybar to Atlanta. Several townships on the east are crossed by the stage road north from Idaho City and Placerville. These are the only passable roads in the region, because they are the only roads that are kept in repair. There are good trails everywhere, and any part of the reserve can be quickly reached on horseback. For the proper development of the timber and mining resources more roads will be required, and these roads will of necessity be very expensive. The National Government will assume the responsibility of making and caring for these needed roads. The cutting of mining timbers does not seem to have seriously injured the forests, as only the larger and better trees have been cut. If the cutting were controlled by reserve restrictions, as to diameter and location, the supply could in many cases be maintained, if not increased, to the immense advantage of the mining industry. This is also true in regard to the lumbering industry. If lumbering in the region could be controlled by the forest reserve administration the results to all parties concerned would be of great advantage.

The region is very rich in minerals, as is shown by existing mines, and it is greatly hoped that it may become in the future much more important as a mining district even than it has been in the past. No ore is shipped out because of the roughness of the country. Consequently stamp mills have to be taken in and set up at the mines.

Next to lumbering sheep grazing is the great industry in this proposed reserve. There are probably not more than 500 head of cattle in the entire area and these along the southern border. The question of grazing cattle will never be an important one. The fact that the altitude is too high to allow successful farming operations makes the region especially adapted for grazing.

Because of the selfishness of a few sheep owners, who object to proposed forest reserves because they practically control them with their own bands of sheep, and because of the short-sighted and inconsiderate opposition of other sheep owners to forest reserves in general, the impression has gone out that the sheep men are the ones who are rhiefly opposing the creation of forest reserves throughout the West. The most intelligent and far-seeing sheep owner's understand fully that the creation of forest reserves within proper limits will be tremendously to their advantage. I am quite certain that the few sheep owners who object to the creation of properly designed forest reserves do not fairly represent the opinion and best judgment of the sheep owners as a class.

I can not do better than by giving the report of the forestry department on sheep grazing in this proposed Sawtooth Reserve. It $5245-$ No. $67-05$ มI -4 
will serve greatly to clear up any misunderstandings which may have arisen in the minds of sheep owners as to the views which the forestry department takes of this great industry in relation to forest reserves.

I commend the following to the careful consideration of all those who are interested in the sheep industry:

That the region is especially adapted for grazing is eridenced by the fact that the general altitucle is too high to allow of successful farming operations. There are very few level hasins or benches where farming could be carried on, if it were possible, and the whole region is rough and abrupt, with slopes and ridges which are covered with an herbaceous and shrubby growth so valuable for the grazing and browsing of sheep. Water is abundant in springs and streams, and herders can drive their sheep everywhere with the surety of finding plenty of water. The region so far has been used only for summer range, the sheep being driven into the low sage brush hills along the Snake or westward along the lower Payette for winter pasturage. Because of the high altitude with consequent long winter seasons of deep snows, the proposed reserve region will probably never he used for winter range. The sheep are driven into the hills early in May, and snows drive them out again in middle September. so that the real grazing season is a short one. There are no lambing grounds in the region, these all being southward along the snake River, where. becaluse of much lower elevation, the winters are milder.

The sheep are owned largely in Boise, though a few bands come in from Mountainhome on the south, Hailey and Ketchum on the east, and Caldwell and other points on the west. Exact figures as to the number of sheep in the region were not attainable, but a well-known sheep man gave an estimate of 50,000 head. In stanley Basin, Bear Valley, and other basins surrounding this reserve there are many times this number. Pratt \& Son, of Boise, last year ran about 15,000 sheep in and abont the Bear Valley country, largely outside of the proposed reserve. To the northward, in Rear Basin, Cupp \& Son, of Caldwell, were rumning 12.000 sheep.

On the Boise market the value of sheep per head was given at $\$ 1.75$ to $\$ 2.75$. These are fall prices and include best spring lambs. Wool was quoted at 19 cents. Counting $\$ 2.25$ per head, the sheep industry in this region represents a capital of $\$ 67,500$. This is probably a low figure, as accurate returns could not be found.

Iany excellent localities for sheel have nerer been grazed, and some of the best grazing grounds at present hare only been grazed for the past two or three rears. Only within three years have sheep been put into Bear Valley, which is an excellent sheep region, and so far no injurious results could be observed from their grazing there. Being so far from winter pasturage, sheep can only remain in these higher valleys a comparatively short time. But the industry has been so profitable that new owners are putting bands into the hills everywhere, and unless restricted within a short time the region will be hadly overgrazed. This overgrazing will not only seriously injure the sheep-raising industry in itself by destroying desirable range, but will also greatly injure the reproduction of raluable tree species on the hills and higher divides: destroy the protective covering of the hills, so that the water-conserving power will be lessened, and will so loosen the forest débris and soil that every serere rain or spring flood will cut deep into the hills and fill the rirers. and hence the ditches below, with silt and débris. With the exchusion of sheep from a few important ridges and higher slopes, corered at present with rouns forest growtl. and with slight restrictions as to numbers to be grazed and time of entering the region, nany more sheep than at present conld be grazed without damage to the forest or watersheds.

As cattle will probably never be ranged to any extent in this proposed reserve the usual dispute as to range areas between cattle and sheep men will not be a factor in the administration of the reserve. So far the matter of range areas has been settled among the sheep men to some extent by the State Wooi Growers Association, but this has been unsatisfactory in many wass, and sereral large sheep owners have declared themselves in faror of a forest reserve if it would allow of definite allotments of areas and require small sheep owners to respect these allotments. Mr. W. L. Cupp, of Caldwell, who runs 12,000 to 18,000 sheep on the headwaters of the IIddle Payette and in Deadwood and Bear basins, says, "I am more and more in favor of this region being made a 
forest reserve. Outside sheep men rushed their bands onto the range this year (1904) long before the regetation warranted it, and I believe the damage wili not only be for this year, but will be lasting, and eventually totally destructive unless something is done to regulate time of entry of slieep and bring about definite allotments of range."

Some injury has been done to the range throughout the region by grazing of: sheep, but that greater injury has not been done is probably due to the following causes :

(1) The shortness of the season-from the middle of May to the middle of September.

(2) Number of sheep have so far been low enough to prevent overstocking of the range.

(3) Because of the altitude, the amount of snowfall and rain is great, and hence the growth of herbs and shrubs is correspondingly great, and they renery themselves each year before the sheep come onto the range.

The principal herbs and shrubs upon which the sheep feed are: Several bunck grasses, redtop, wild oats, fireweed, sereral small composites, willow, aspen, wild currants, and various species of sage brush. These occur everywere along the streams, in open parks, and over much of the so-called woodland.

The method of running sheep is the same here as throughont much of the West. The sheep are run in bands of from 1,200 to 2,200 and taken care of by a herder, who generally has several trained dogs to assist him. A large owner will have several bands in one region, and will supply the herders with food and the sheep with salt from a central camp. There are usually two or three camp tenders, who bring in supplies with pack animals and also more the night camps of the herders and keep them in food. The main camp is seldom moved during a season, and general supplies are brought in at intervals rather than all at one time. Because of poisonous plants, wolves, bears, and other dangers there is always a small per cent of loss. There have been a few instances of the total loss of whole bands by remaining in the hills too late in the fall and being snowed in.

As previously stated, with a few restrictions as to numbers and time of entry, the whole area can be used as a summer range for sheep. With the present knowledge of conditions on the rarious watersheds, it will be safe to allow the grazing of 75,000 sheep and 5.000 cattle. This number can be enlarged or restricted later by the supervisor as he becomes thoroughly acquainted with the region. Many more than are in the region at present can doubtless be allowed. The small area in Custer and Blaine counties, east of the ridge of the main Sawtooth Range, should be kept entirely free from sheep. The Redfish Lakes are here, and to preserve them in their natural beauty sheep or cattle should not be allowed to graze about them. What natural range there is about the lakes is only sufficient for the horses of campers and people who seek this region for health and recreation. Rights of passage for sheep from the winter range to the south and west have been agreed upon by the State Wroo! Grower's' Association, and should be allowed as at present until outlined and controlled by reserve officers.

Almost the entire reserve has been burned over, and many causes are assigned for the fires. No large fires have occurred in recent years. With the natural obstructions to fires which exist within reserves it will not be difficult to protect the forests from fire in the future.

The national Reclamation Service has commenced projects for a canal and reservoir system on the Payette and Boise rivers, which contemplates increasing the present irrigated area in the Boise Valley from 80,000 to 334,000 acres, and adding 40,000 acres to the irrigable area of the Payette Valley. This means the creation of about $\$ 20,000,000$ worth of realty in addition to the other immense benefits which will follow.

The plans of the Reclamation Service consider the connection of the Payette and Boise river's by canal, so that both these rivers must be discussed as one. At the present time the Payette carries anough water for all available land of the Payette Valley, but under the pro- 
posed irrigation system all of the waters of the Payette will be used. and Payette Lake must be made a reservoir. There is no difficulty about providing a canal system to convey water to the lands. The problem is the storing of the spring floods for use at a time when the natural stream flow gires out. The greatest discharge of water by these streams occurs in the months of May, the rise commencing about the second week of April and reaching the lowest level gradually about the last of July. There is ample supply of water for the irrigation of all a vailable lands, but careful storage will be needed for the maturing of crops over a larger acreage Every advantage of forest protection on both these streams is necessary to carry on silccessfully the great irrigation enterprises which the Government has undertaken.

The larger sheep owners, as a rule, favor the establishment of the reserve. They realize that it will prolong grazing in the region, as an industry, and will insure them a clefinite range area which they are not certain of now. The opposition among sheep men has come either from one of two large owners who wish to monopolize the whole industry in that region, or from smaller owners who misunderstand the real purposes of the reserve and who believe the larger owners are back of the movement, and, if established, the reserve would be controlled by these large owners.

Miner's who understand the regulations in regard to the development of mines in the reserves, are farorable to the movement. The opposition from the miners, the same as is the case with the sheep men, comes largely from a misunderstanding of what a reserve means. so far as it affects their individual interests.

The most active opposition to this proposed reserve is found among some of the large lumbering concerns who have large holdings near or surrounded by the reserve. I will again quote from the Forestry Bureau the advantages which will come from the establishment of this reserve. I am glad to do this because it will show plainly the object which the Administration seeks to accomplish not only on this particular reserve but in all reserves and should go far toward quieting the fears of those who think that the particular industry in which they are engaged will be injured by the creation of the reserve. The advantages will be as follows:

(1) That all of the proposed area is at such an altitude and has so short a grazing season that farming is not practicable.

(2) That there is great need for the protection of the watersheds of all streams flowing west and south, not because of the use of water in the area itself, but for the large irrigation interests along the lower waters of these streams.

(3) That the present grazing area will not be limited, but be extended, and that the proper division of the range will consider more fully the interests of all sheep owners, and that the range will be so guarded that it will not be overgrazed and destroyed and the future of the industry ruined.

(4) That the present continual danger from fires, set by prospectors and sheep herders, will be reduced to a minimum by having necessary regulations thoroughly understood by all who enter the reserve and effectively carried out by the reserve officers.

(5) That protection to the forests will cause their renewal and 
extension and make them better protection to the watersheds. This will result not only in a greater regularity in the flow of the streams, but probably an increased flow, which will be so valuable for irrigation along the streams rising within the reserve.

(6) That the cutting of timber by miners, settlers, or lumber concerns will not be prevented, but merely regulated, so that the conserving power of the watersheds will not be injured, and young growth will be so protected and aided that a continuous supply of timber for future generations may be guaranteed.

(7) That only a reserve administration can carry out a policy that will not only aid and protect present industries, but insure to future generations the benefits in the way of grazing, timber, and water supply which are being enjoyed by the few to-day.

Therefore, that the greatest benefits may be derived both for the present and future generations and because of the great good that will result to the State at large, and consequently to the whole country, without retarding or injuring the present industries of the region, it is recommended that the proposed Sawtooth Forest Reserve be established.

Senator Heyburn objects to the Sawtooth Reserve officially, and I quote him accurately. My colleague says:

My objections to the Sartooth addition are based upon the fact that it includes the town of Banner, which is a prosperous and growing community, and that its growth would be stopped by the creation of a forest reserve over it; that it also includes the town of Atlanta. which is one of the oldest towns in the State and in which millions of dollars are invested in mining and kindred enterprises, and which after a long period of stagnation incident to the finacial rererses of a few years ago has just started on a new growth with renewed energy; that it also includes Rockybar. notwithstanding that a narrow strip has been omitted along the road from Mountainhome into that town. This is one of the oldest towns and sections in the state, and the settlements are spreading erery year in every direction from this center. It also includes the new settlements of Edna and Sawtooth, and crowds close down to Pioneerville, one of the oldest mining towns in the Boise Basin. As I suggested in a personal interview with you in regard to this matter, a timber reserve might be safely created running along the watershed to the northeast of Banner. The towns I have mentioned have schools, churches, homes, and permanent settlements which would be rendered comparatively useless by the creation of such reserve. This reserve should be confined to the mountains above the settlements and towns. It also includes Twin Springs, which is at the head of the Boise Valley and near Boise Basin.

In regard to this reserve, also, my colleague either does not know the facts or he totally disregards them. "His argument is based wholly upon the premise that many prosperous towns are to be included, and that the effect will be to destroy them. I surely think that Senator Heyburn in discussing a matter of so much moment to our State should have been very careful as to his facts.

There is but one settlement (Atlanta) in the entire area large enough to have a post-office. Rockybar, Sawtooth, and Twin Springs are not in the proposed reserve at all. Even if all that he says is true, and should this region fulfill its promise of great mineral development, which I believe it will and which I sincerely hope it will, the existence of a properly managed reserve will be of advantage. No industry needs protection against the destruction of wood and water more than mining.

The part of this reserve-the southern portion-which Senator Heyburn objects to especially covers the headwaters of the Boise 
River, and the Reclamation Service emphatically declares that upon its creation largely depends the success of the Boise Valley irrigation project.

\section{PAYETTE FOREST RESERIE.}

Tre now come to the proposed Payette Forest Reserve.

This reserve is in central Idaho, and occupies portions of Idaho, Boise, and Washington counties, and contains about 1,381,376 acres, most of which is unsurveyed. This reserve is designed chiefly to protect the watersheds of the North Payette River and several tributaries of the Salmon. Nearly all of this area is within the addition to the Bitter Root Forest Reserve, embraced within the withdrawal of 3.000.000 acres in November, 1902, on the suggestion of the Reclamation Service. It constitutes the only portion of the Bitter Root Forest Reserve south of the Salmon River, and for the adrantages of administration it is recommended as a separate reserve instead of as an addition to the Bitter Root. Reserve, as was first contemplated.

It is a high, forested mountain region, subject to a heary snowfall, and gires rise to many large streams which supply water for immense a gricultural districts in southern Idaho. There is scarcely any cultivable land within this reserve. The soil is poor and the country exceedingly rough. Nearly half of the area is almost worthless for any purpose except that of protecting the streams. It is too inaccessible even for grazing and contains little promise of mineral.

The forest consists of bull pine, red fir, tamarack, lodgepole pine. and balsam. The cultivable lands all together consist of about 5.000 acres.

There has never been any lumbering within the proposed reserve. nor is there likely to be any great demand upon it for many years unless for the use of small mines. The timber ought to be protected. however, for some time in the not distant future there will be a demand, when the other and umreserved timber of Idaho has been destroyed, and that destruction is wasteful and almost criminally rapid now. It is as a conservor of irrigation waters, however, that this region demands the greatest consideration. The Payette River is one of the most important streams which flows through arid agricultural Idaho; and if the spring run-off is hastened by the destruction or denudation of the watersheds, the success of the Boise-Payette irrigation enterprise will not be possible. Fire is the great destructive agent in this region, and the loss on this account can be minimized through forest regulations. While the region is naturally adapted to sheep grazing and should be devoted to it, regulations for its protection, as well as that of other interests, should be established and enforced. No industry will be injuriously affected by the establishment of this forest reserve, and. on the other hand, irrigation, stock grazing, and mining interests will be benefited. Some sheep men and those who are hostile to the forest-reserve policy in general oppose this reservation; outside of these comparatively few, sentiment generally farors it.

Senator Heyburn officially opposes the creation of this reserve in the following language. I quote him:

With reference to the Parette addition, $m y$ objections are based upon the fact that it includes a rast quantity of land upon which there is no timber. It also 
includes the town of Warren, a settlement since 1862 , around and about which are some of the best mines in the State of Idaho. This reserve has evidently been selected without any personal knowledge on the part of the selector of the conditions upon the ground in this section. It covers a considerable portion of the State wagon road, constructed by the state to enable settler's to get into this very country. This reserve cuts off the Thunder Mountain mining country from the north by a barrier which amounts to a prohibition against those who desire to operate these mines from that direction. and they are easier of access from the north than from anywhere else. The reservation covers a linge amount of the mining country now being taken up and settled about and adjacent to the 'Thunder Mountain district. To withdraw it is to paralyze the rapid growth now going on in that section of the country.

The map furnished me does not indicate the fact with certainty, but I believe the proposed reserve covers the Thunder Mountain mining district and the town of Roosevelt. which is one of the most rapidly growing and prosperous new places in Idaho. There are several thousand people in that section of the State who went there with the intention of staying. provided they could have the rights of settlers in other sections of the country without being "supervised."

Again my colleague throws facts to the wind. In reading the official objections of my colleague to these proposed forest reserves, I fear that he has been thinking of " jack-o'-lanterns" so much that he constantly uses them through force of habit.

Every portion of this reserve has been traversed and carefully studied by the most competent examiners of the Forestry Bureaur. The timber has been mapped and photographed. and the only complete and reliable map of this entire section in existence has been prepared and will be published by the Forestry Bureau. This detailed map shows that 50 per cent of the area is covered with commercial timber, 34 per cent is woodland, and 13 per cent is burned and cut-over forest land, which will restock, yet my colleague asserts it as a "fact" that it includes vast quantities of land upon which there is no timber.

It will not interfere at all with the State wagon road, but will be a protection to it.

The Thunder Mountain district and the town of Rooserelt are 20 miles in an air line from the proposed reserve, and its residents are not and can not be affected in any way.

The mining supply station of Wirren is the only settlement within the proposed reserve. It is a supply point and freight station, and nothing but the possible development of minerals will ever make any towns, or even scattered population, of any importance within the area.

PROPOSED ADDITION TO THE BITTER ROOT FOREST RESERVE.

I have already stated that something over $1,300,000$ acres of the $3,000,000$ acres which was withdrawn from entry in 1902 on the recommendation of the Reclamation Service, to be included in the Bitter Root Forest Reserve, has now been set aside for the proposed Payette Forest Reserve. North of the Salmon River it is proposed to add to the Bitter Root Forest Reserve a tract of 4.52,357 acres, which is nearly all within the withdrawal mentioned.

The present boundaries of the Bitter Root Reserve include but a small part of the timbered region between the Salmon River and the south fork of the Clearwater. All of this proposed addition, excepting about 20 per cent, possesses suitable climate for the growth of commercial timber. It is entirely unsuited for agriculture. One-half of 
this proposed addition of 452,357 acres is corered by fine commercial timber, but owing to the absence of a market and transportation facilities the use of this timber has been prevented for anything but road construction and building. Near Grangeville the better timber has been taken up under the homestead and timber and stone laws, and small sawmills are in operation, but extensive logging can not be expected for many year's.

Only two mining districts have been discorered in this proposed addition. In 1860 rery large placer deposits were found on the broad Salmon River summit at Florence. Something like $\$ 50,000,000$ in gold was taken from this district from 1860 to 1885 . Placer work ceased in 1990 . Since then a number of very promising quartz mines have been discovered and partly developed. I believe and sincerely hope that splendid mines will be discovered and dereloped. If this hope will materialize these mines will need timber, which it will be difficult for them to get in the neighborhood, for the forest district around Florence was almost completely burned over, and there will be no arailable timber there for many year's. Placer gold in paying quantities has been found also along the south fork of the Clearwater. and they are being worked now. There is enough timber to last these placer mines for a great many year's in the immerliate neighborhood.

Nearly the whole addition is unsurveyed. There are about 1,000 acres of land under cultivation, and about 4.000 acres of land will be taken up under the homestead law when the land is surveyed. As nearly all the agricultural land is already taken, no damage will result to agriculture on account of this proposed addition.

The immense tract of agricultural land which is known as the Camas Prairie. with the slopes of the Clearwater, adjoins the addition on the northrest. There is sufficient rainfall in this entire region for the growth of all crops. and the supplying of water for irrigation does not enter the problem. The ranchers along Salmon and Clearwater rivers are chiefly dependent upon cattle and their stock summer range in the proposed addition. The reservation of this tract will in no way affect this cattle industry. There is sufficient timber outside the proposed tract to furnish finel, posts, rails, etc., for the needs of settlers for a great many vears to come.

The roads which have been built from the supply points of Grangeville and Stites to the mining districts of Florence, Buffalo Hump. and Elk City pass through the proposed addition, and all parts of the region are easily reached. A stage line along Salmon River, connecting Council and Grangeville, also passes near it on the west. The nearest railroad is a branch of the Northern Pacific which extends up the Clearwater River to Stites. It is almost assured that an electric line between Lewiston and Grangeville will soon be built.

None of the timber of the proposed addition has ever been entered by lumbermen as yet. Practically the only demand for sawed timber is from the Camas Prairie settlements, and there is enough timber nutside the proposed addition to meet all these demands for a number of rears. The only immediate demand for reserve timber will be confined to free use permits by ranchers and miners within the tract. Thus on account of its remoteness and present inaccessibility, the timber in this proposed addition is not valuable now commercially, but the time will come in the future, when the timber in northern Idaho is 
exhausted, when it will be of great value, and it onght to be preserved.

No part of the proposed addition is safe from fire. 'The area of the forests which is untonched by fire is becoming smaller each year, and from its position can not be expected to escape much longer unless it receives protection. In the northern portion of the addition are two areas of commercial timber. separated by the South Fork of the Clearwater, which have been but slightly injured by fire. Both possess the conditions which give rise to the most destructive fires, and strict regulations are needed if they are to be saved.

Taken as a whole, the area possesses but few resources or industries which will be influenced in any way by its inclusion in the reserve. I am aware of the fact that the local sentiment surrounding this territory is generally adverse to the proposed addition. I think this is owing to a misunderstanding. The only class which will be affecter at all by including this area in a reservation are the cattle owners who use the range, and they will be benefited. Cattle grazing has nowhere wrought any injury to the forests, and even where sod is formed, reproduction universally follows cattle raising. Cattle and stock grazing will always be allowed on the proposed addition. Three times the number of cattle which now graze in this region can safely be permitted there, and the local cattlemen will be protected and preference given to them over outside cattlemen. Sheep do not range in this section to speak of now, but provision also can be made for them withont disturbing the cattle ranges, as some portions of the forest reserve are suitable for sheep grazing. but not for cattle grazing. The district is well supplied with roads and trails, but the Department will take it upon itself to improve old trails and to construct new ones between such points, for instance, as Mearlow, on Meadow Creek, to Corral Hill. Also from Adams down Slate Creek to Freedom, or at any rate a trail which will connect Adams with the trail from Little Slate Creek to John Day's.

The land to be reserved in the proposed addition is nearly all public and unsurveyed. It is divided as follows:

Homestead entry or patent Acres.

Timber and stone patent

School land - 1.920

Public land -

Senator Heyburn protests against this reserve in the following language:

As to the addition to the Bitter Root Reserve, which includes the torns of Newsome and Florence, there is absolutely nothing to be said in faror of it. Like the Bitter Root Forest Reserve, it is at the head of streams flowing into regions where irrigation is not needed and where the complaint is "too much water" rather than not enough. The town of Florence, which was settled in 1862 , and which, with its immediate surroundings, has produced over $\$ 100,000,000$ in gold, is still a flourishing and producing country and is built up with schools, churches, public institutions, and homes. A statement of these facts should in itself be sufficient to make the consideration of the creation of a forest reserve impossible.

I have already discussed the town of Newsome in a former protest. It is a growing and prosperous town on the State wagon road. The country lying between these two points contains some timber, but it is worth infinitely more for horce-making and agricultural purposes. 
Again my colleague has not informed himself and ignores facts. This proposed addition does not include the town of Newsome. The town of Florence consists of a hotel, stable, and one or two stores. The placer's which caused the building of schools, churches, and public institutions and homes have been worked out, and there are no producing mines or dependent population in and around Florence. I sincerely hope that great quartz properties will be found at the very doors of Florence. This reserve will in no manner interfere with the prospecting for these quartz mines, nor for their proper development if found, nor to the building up of Florence again if great mining derelopments take place. If paying mineral in quartz shonld be found, timber will be required and should be guarded not only to supply the mines, but on account of its own value to future generations. Nearly all of this proposed addition is capable of producing timber, but there is no area in Idaho which is in greater danger from fire.

\section{SQUAW CREEK DIVISION OF THE WEISER.}

This proposed reserve contains 295,784 acres and forms the divide between the Weiser and North Payette rivers and is the source of much of their tributary water. About one-half of this total area is covered with commercial forests.

While there are large areas of agricultural and timber lands bordering the proposed reserve which have been acquired by settlers and lumber companies, in the tract itself there is but little more than 1,000 acres of agricultural lands. All the surrounding agricultural settlements are dependent upon timber and water from these mountains, but it is the serions shortage in the Weiser Valley which demands every protection possible not only of the forest, but of the lower and ground regetation.

Nearly all of this reserve affords excellent pasture, but it has been overstocked by outside sheep. The protection of stockmen residing near the reserve and of a range peculiarly sensitive to overstocking and which immediately influences the forest growth and the flow of water makes grazing regulation exceedingly important. There is no necessity to prohibit sheep grazing. On the other hand it is the design to protect it.

The only opposition to the reserve apparently is due to a misunderstanding on the part of the sheep men, who have been led to believe that sheep will be excluded from the reserve.

Senator Heyburn's objection to this reserve is rather mild. I quote him:

The Squaw Creek division of the Weiser Reserve has some merit, provided that Garden Valley at the lower end of it is omitted and township 17 north. ranges 1 east and 2 east, and township 18, 1 east, are eliminated, inasmuch as a line of railroad is now actually constructed to council and is under contract for an extension orer these rery lands.

Although my colleague graciously allows some merit to this reserve, as usual he is totally oblivious as to the facts. Garden Valley is not included within the reserve and there is no intention and never has been to include it. There is no good reason why the three townships which he mentions should be restored, as the right of way of the road only goes through the proposed reserve for 6 miles, and then traverses only one edge of one of these three townships. 
This proposed reservation is situated in the southern part of Cassia County and includes 323.520 acres.

The principal streams rising in the area are Goose Creek, Rock Creek, Trapper Creek, and Shoshone Creek, together with smaller creeks, such as Little Cottonwood, Dry, and Beaverdam creeks. The flow from Goose Creek and Rock Creek water large tracts of land. The smaller streams, although they go dry in the summer, are used for early summer irrigation.

Seventy-five thousand acres of the entire reserve are more or less timbered. The remaining 258,000 acres are corered with sage brush and chaparral.

Rock Creek, which rises in this area, has a flow of water in the spring of 7,000 to 8,000 miner's inches, but during the summer this falls. off to 200 inches. Dry Creek, which has a fairly large watershed, nearly equal to that of Rock Creek, is dry during the summer and fall. These conditions also prevail on Trout and the two Cottonwood creeks, which flow north from the mountains. Groose Creek, the most important stream rising in the area, the waters of which are utilized for irrigation to the last drop. has a greater fluctuation of flow than Rock Creek. It is an established fact that protection cover on a watershed is necessary to prevent erosion and regulate the flow of streams, which shows how necessary the protection of the growth on these watersheds is to the farming communities below.

There are ranches on every creek flowing from the reserve, and every ranch is devoted principally to raising hay for winter feed. Oakley and Rockcreek are the only towns of importance near the reserve.

The great Twin Falls Land and Water Company has constructed canals diverting water from Snake River from a point 23 miles above Shoshone Falls, bringing it to immense tracts of land to the east, north, and west of the proposed reserve.

The ranchmen in the vicinity of the proposed reserve are dependent upon it for fuel, fencing, and house logs, and these timber lands on the reserve are the nearest to those who are going on the Twin Falls lands, and these settler's are removing quantities of material from this area.

There is no opposition to this reserve among people of that section, unless it be from a few sheep men.

I do not recall having seen any objection to this reserve by Senator Heyburn. I am quite sure that he has not as yet made objection to it in his official capacity.

I will now summarize the forest reserve situation in Idaho.

Whether or not forest reserves are a good thing in Idaho or any other State depends mainly upon the answers to these three questions: Are the important industries of the State, consequently also its general welfare, dependent upon its timber and water supply? If so, are these resources where there are no forest reserves so wisely used, so effectually guarded, that it is safe to assume that they will be permanently adequate to meet every future demand? And if the first can be answered affirmatively, and the second can not, is it desirable to assure the community such protection? 
Agriculture, mining, and lumbering are the most important of Idaho's permanent industries. Upon their continued prosperity depends that of almost every other interest. Agriculture in at least two-thirds of Idaho means irrigation farming. Its relation to forest protection is peculiarly intimate, because the great proportion of cultivable land lies in an arid belt which, even more than in most arid States, has an insufficient system of streams and reservoir sites to draw upon. In many States the reclamation of desert land depends upon canal projects, which, although expensive, are perfectly feasible because there are large streams from which to draw. Southern Idaho has few streams which have not already shown doubtful adequacy. Not only is it extremely difficult to find any unimproved land which has a satisfactory water right, but the old settled districts constantly feel an increasing shortage. These are the conclitions now ; the future will certainly bring more claimants, and unless something is done to protect the streams, it will bring a smaller supply of water to meet the increasing demand. Reservoir storage will help, but the Reclamation Service asserts of practically every project it has in hand that success depends upon sustained forest storage also.

The following figures show the extent and importance of the interests dependent upon irrigation:

According to the Twelfth Census (1900), the 602.568 acres of irrigated land in Idaho was 42.6 per cent of its total improved land. Of the total number of farms, those irrigated constituted 52.6 per cent. The value of all land in the irrigated farms was $\$ 21,850.135$; the value of the buildings thereon, $\$ 4,338,425$, and the investment in canals and ditches, $\$ 5,120,399$; making a capital represented by irrigation farming, exclusive of stock, implenents, crops, etc., of $\$ 31.308,959$. The a verage of all irrigated land was $\$ 31.2 .5$ per acre. while that of the best, suitable for growing fruit, ranges from $\$ 60$ to $\$ 500$ per acre. 'The value of irrigated crops in 1899, the latest year for which figures could be given, was $\$ 5,440,962$.

Nearly all of this land would be comparatively valueless without irrigation, and with irrigation a similar value can be given a great portion of the now valueless area of the State. In the decade between 1890 and 1900 irrigation increased the improved area in Idaho by 37.6 per cent, and added over $\$ 12.000,000$ to its farming wealth. Future development in greater proportion is limited not by a vailable land, but almost solely by available water supply, which can never be provided by reservoir storage unless assisted to the greatest possible degree by forest storage. And the lands covered by the above statistics lie almost wholly on streams rising in the proposed forest reserves recommended by the Department of Agriculture.

Hitherto, except in a few localities, the various destructive agencies have not pushed back into the mountains far enough to denude the watersheds and perceptibly affect the flow of the streams, therefore the water users, while suffering from shortage already, have not learned the lesson of forest protection through experiencing the diminution of supply which follows destruction of the forest. They realize fully the obstacle to further development of arid lands, but base their calculations on the present stream flow without considering the even more serious possibility of the present supply being diminished. It is for these reasons that the water-using classes of 
Idaho have not organized to secure forest protection as much as they have elsewhere, where the necessity has been proved by bitter experience.

I need not argue that mining absolutely requires a sustained supply of timber and water and that its profits are greatly affected by the cheapness of both. The point is whether such farorable conditions are assured to those who are spending their lives and money to develop this gerat industry of Idaho. Experience has shown otherwise. Countless camps have seen the timber and water, second only to ore in necessity to their growth, either destroyed by fire or diminished so as to greatly imperil their future. And now that sawmills are becoming their active competitors, many have not long to wait before the supply which they confidently relied on will be cut before their eyes and shipped out of the State. No industry has more to gain than mining from a system which brings protection against fire and, while freely allowing timber to those who need and have a right to it, against waste and unfair competition.

But while forest reserves protect the local consumer where the supply is rightly his, they do not injure legitimate lumbering. On the contrary, one of their prime objects is to foster and make permanent this industry. Much of Idaho, especially the northem part, is ideally a timber-producing country. It should maintain for all time a lumber business which will employ thousands of men, bring vast wealth to the State, and support a large dependent population in towns and farms. It will be a great misfortune if Idaho repeats the history of most other timber States. If its timber passes entirely into the hands of a few syndicates, and if these employ the usual methods of their great wealth-immense mills and armies of men intent on the greatest exploitation in the shortest time-the permanance of lumbering in Idaho will be doomed. The small mill will disappear, the price of lumber to the miner and home builder will be dictated by monopoly, and in a short time even the big mills will move away, leaving depression in every business following the temporary abnormal stimulus. The timber will be cut while Idaho is too undeveloped to use much, therefore it will be shipped away. When Idaho has grown to need a large supply it will be gone.

The object of forest reserves is to prevent this. All the timber which can be spared will be sold from them, and this will be enough to support a large lumbering industry, but the future will also be kept in mind. The young timber will be protected, fires and waste will be prevented. and local demand will be insured permanent supply.

So closely allied with forest protection that separation is difficult is the use of the public range. Sheep and cattle grazing is the source of much of Idaho's wealth, and the summer range is usually in the regions where forest reserves are recommended. Fortunately, however, the establishment of reserves is an advantage, not an injury. to this interest. While the early policy was not always sufficiently liberal, the Govermment now recognizes the importance of this subject and desires, instead of hampering the use of the summer range, to bring it to its highest permanent utility. On the public domain unrestricted grazing competition has generally resulted in disadrantage to the small stock owners and deterioration in the carrying 
capacity of the range, which is realized too late to prevent permanent injury. Upon forest reserves the aim is to allow all the grazing, either of sheep or cattle, which will not decrease the next vear's supply, and to allot it on an equitable basis. The settler is protected first of all, and other's considered according to their rights or priority and location.

These, then, are the present objects of forest reserves. What valicl objection can be urged against them? Whether it is successful depends upon the administration of the reserves and upon the cooperation of the citizens of Idaho. On February 1. 1905, the administration was transferred to the Department of Agriculture, and the Forest Service of that Department has nearly completed a revision of the regulations upon an entirely new policy. Control from ITashington will be reduced and much more authority given to the local officers. Being on the ground and familiar with local conditions, they will be able to do business promptly, without delay of correspondence and red tape. The present policy is based upon the use of the reserves by the people, with only such restrictions as are necessary to insure the fullest use.

The regulations provide for free use by settlers and prospectors of all the material they need. Large consimers can purchase as freely and as cheaply as from private speculators, although they must not destroy the growth which will provide a second crop. The mining laws apply exactly as they do on outside reserves. Private enterprises. like reservoirs, ditches, telephone lines, stores. and summer resorts, are allowed upon application. Grazing is regulated only so far as necessary to prevent destruction of the range or unfair competition. Better pay will be given forest officers and better men secured for the service.

Forest reserves not only do not hinder derelopment, but they actually assist it in many ways. For example. outside of them there is usually no legitimate way to get timber except by buying the land. which can not be done unless it is surveyed. Cutting on unsurveyed land is usually trespass, punishable by fine or imprisoument. On a reserve timber may be obtained anywhere for any purpose. To secure any legal right of way on the public domain requires compliance with cumbersome laws calling for expensive plats and surveys and necessitating long delays. The new regulations for forest reserves allow permits for all small projects, with no red tape or waiting. On the public clomain no one can legally operate a store. hotel, or any other establishment unless he can establish a claim to the land. If it is not agricultural land, or if he has used his homestead right. he usually has no way except to locate a mineral claim, regardless of whether he can hold it as such legally. He is alwars at the merey of the claim jumper. On a reserve he has only to secure a permit to occupy the land for the desired purpose and the Government protects him.

A very important aid to the public which is to be provided under the present management will be the active building and opening of roads and trails. The lack of trails and bridges is a great inconvenience throughout nearly all mountain regions in Idaho, and the forest service expects to devote much time and money to this purpose.

These conditions should remove most of the objections which have been made against either existing or proposed reserves in Idaho. No 
less important in its bearing upon the matter is the present system of establishing reserves. None are recommended without the most careful examination and consideration of all points. Temporary withdrawals pending such examination may include unsuitable land and give color to hasty protests, but the permanent lines are drawn to exclude practically all agricultural areas, and the remainder is restored to the public domain. The examinations are thorough and by men intimately familiar with western conditions.

I will state at this point that the Shoshone Reserve and the Kootenai Reserve have not ret been recommended. Withdrawals have been made. Careful examination is being made, but the permanent lines have not yet been drawn. Care will be taken, so that the best interests of the State and of every industry will be promoted when these reserves are established.

To sum up, the Government makes forest reserves for no other purpose than to protect and manage them, at its own expense, for the benefit of the State and its home builders. It is anxious to do this acceptably to the present and future population. The occasional friction is nearly always due to misunderstanding of either the objects or the regulations of the reserves. Mistakes can not always be a voided by either side. nor can systems or officers be perfect, but improvement will be faster if the people will cooperate and if critics will devote their energies to correcting errors instead of trying to abolish any system for the protection of Idaho's resources.

In conclusion, and as I stated in the beginning, the present national policy in regard to irrigation and forest reservations is not the creation of President Roosevelt and his Administration. This policy has been established by the Senators and Representatives from the Western States after years of concentrated effort. They fought the creation of forest reserves during all administrations, from Cleveland down to the Administration of Roosevelt, because the reservations were set aside without proper investigation, and the administration of the reserves was carried on loosely and by incompetent and brokendown local politicians in the field, to the injury of our section. All defects and abominations of the system were discussed in public debates on the floor of Congress until they have been removed. The western Representatives pointed out not only the faults, but suggested the manner in which these reserves should be administered for the benefit of the West. These suggestions were gradually adopted, one by one the abuses were done away with, and to-day forest reserves are administered by the present Administration for the sole purpose of conferring the greatest benefit on the communities in which the respective reserves are situated. This policy is now fixed, and it is the policy, as I have said before, which has been established by the united efforts of the Senators and Representatives in Congress from the section of country affected.

Politics has never at any time divided the western Representatives in their policy on irrigation and forest reserves. They stood unitedly against the powerful influences which were brought to bear to allow the National Government to lease our lands. Unitedly they successfully combated the attempt to turn all of the public lands over to the respective States and Territories with the proviso that these States and Territories would reclaim them, and unitedly they framed the present national irrigation law, under the provisions of which the 
National Government is pledged to the reclamation of lands in the arid and semiarid country, and every Senator, Representative, and Delegate in Congress supported with all his vigor this national irrigation law, and with that support it could not fail of passage. While the western Representatives were fighting the leasing of our public lands and the turning over of the public lands to the different States and Territories, they secured the passage of the national reservoir act and of the national Carey Act. Under the Carey Act something like 500,000 acres of land are now under process of redemption in Idaho. President Roosevelt threw his powerful influence in faror of the national irrigation act, which was the culmination of years of imited and concentrated effort by the Representatives of the West. President Roosevelt adopted this policy of the western Representatives in regard to irrigation, as he adopted the policy of the western Representatives in regard to forest reserves, and he is the first and only President who has done so.

It is altogether becoming, it seems to me, that the western Representatives should continue unitedly to uphold and sustain the President in carrying out policies which they themselves established.

The tendency in our State is to part with our valuable timber and agricultural lands too readily. This is a mistake. We should conserve and protect our forests, which are not of great value now commercially, and we should be very careful about selling our commercial forests. Te should not be in such a hurry, either, to dispose of our agricultural lands.

I have a right to discuss these matters, because I had the pleasure and honor of introducing and passing the bill when we were admitted as a State. by which the National Government gave to our State hundreds of thousands of acres of land for the support of our schools and various institutions. I put the minimum price on these lands at $\$ 10$ per acre, and recall very distinctly how sharply I was criticised from one end of Idaho to the other for putting the price so high: it was contended that the land never would be taken at that price and development of the state would be stopped. Scarcely anyone encouraged me in my contention that none of our State lands should be sold for less than $\$ 10$ per acre, and the usual cry was heard that I was retarding the State's growth.

'This magnificent donation of the General Government to us in lands ought to be carefuly guarded and held as a legacy, so far as is compatible with proper State pride and government, for our children and our children's children. It is a magnificent heritage and was not given to us to squander in our own generation.

About 1,000,000 acres of land are now under process of reclamation in Idaho under the Carey and national reclamation acts. Under these two beneficent acts, added to what private enterprise will do, it is safe to say that from $1,000.000$ to 2.000 .000 more acres will be under process of reclamation before many years. The value of the State lands will increase. and there is no necessity, so far as the proper development of our State is concerned, that there should be undue anxiety to dispose of them now.

This is true also of our timber lands. The timbered forest reserves do not stop or retard in any way the derelopment of our State. nor injuriously affect any industry. This lind should be protected if 
only for the sake of the timber, but in addition to that the creation of these reserves is in the interests of cattle and sheep owners.

Most important of all, howerer, so far as south Idaho is concerned, our great national irrigation enterprises can not be carried on anywhere successfully unless the great watersheds, with the sources of the streams, are protected. Forest reserves in south Idaho and irrigation are inseparable.

There is no reason why we should be in haste to part with our timber or agricultural lands. The State does not need the money. and it is dangerous to pile it up in the treasury. A large amount of money on hand which is not needed to properly carry on the affairs of a State government is a menace. It leads to extravagance, if not to corruption. It has a tendency to create positions for politcal favorites which are neither needed nor useful. With a large amount of unused money in the treasury the expenses of the State administration steadily and unduly increase. The next administration, instead of dropping off from the number of employees and curtailing the extravagance in the different departments. hold on to what they find and add to the number of officers. The increase in our population and the assessed valuation of our property does not begin to justify the increase in the cost of our present State administration, as compared with the expenses which the builders of our State government consider just, if not liberal.

We have legislated for public institutions for which large money appropriations have been made and for which there is no adequate need, and the object of legislators from the different counties is to secure appropriations of money for something in their county, and the ambitious State politicians willingly aid them. A large surplus of money in the treasury of a State or nation is the surest method of debauching a people. Such a surplus is indefensible if accumulated at the expense of a rich legacy.

Respectfully,

Fred T. Dubois.

\section{Senator Dubois to Editor Boise Statesman.}

Wasmington, 1/ay 1:5, 1905.

My DEar SIR: I inclose you a communication in the form of a circular from Secretary of Agriculture James Wilson to Gifford Pinchot, who is Forester, dated February 1 last.

This communication sets out plainly the intention of the Government in regard to forest reserves.

I wish you would publish this, especially the portion which I have marked, so that the people of our State may understand just what the purposes to be accomplished by the creation of forest reserves are. Unless it is assumed that President Roosevelt. Secretary of Agriculture Wilson, and Forester Pinchot are deliberately attempting to deceive the people it is our duty, it seems to me, to aid them in the great work which they are endearoring to accomplish for our country. It is a matter of very great concern to us. They are entitled to our most earnest and cordial support.

Sincerely, yours,

Editor Boise Nitatrismax.

Fred T. Dubois.

Boise, Idaho.

5245-No. $67-05 \mathrm{M}-5$ 


\section{UNited STATES IEPARTMENT OF AgRicultike. \\ OFFICE OF TIE NECRETARY. \\ W'ashingtom, l). C., February 1, 190\%.}

The Forester.

Forest service.

Sin: The President has attached his signature to the following act :

AN ACT Iroviding for the transfer of forest reselves from the lepartment of the Interior to the Iepartment of Agriculture.

Be it enacted by the senate and Homse of liemesentatires of the Inited states of America in Commess assembleal. That the serestaly of the Inelartment of Agriculture shall, from and after the passige of this act. "xecute or caluse to be exeruted all laws affecting jublic lands herotoforo or hereafter rescred under the provisions of section twenty-fomr of the art entitled. "In act to repeal the timber-culture laws. and for other jurloses," alproved March third, eighteen hundred and ninety-one, and acts supplemental to and amendatory thereot, after such lands have been so reserved. exrepting such laws as affect the surveying. prospecting. locating. anpomiating. entering. relingushing. reconvering. certifying. or patenting of any suchl lankls.

SEc. 2. That pulp wood or wool julp manutaletured from timber in the district of Alaska mar he exported therefrom.

SEc. 3. That forest supervisor's and laugers shall he selecterl. when practicable. from qualified citizens of the states or 'Territories in which the said reserves, respectively, are situited.

Sec. f. That rights of way for the (*) wstruction and maintonance of dams. reservoirs, water plants. ditches. Humes, jifus, tumnels. and ranals. witluin and across the forest reserves of the Initel states, ale hereloy grantel to ritizens and corporations of the I'nited states for municipal or minims purpos(s, and for the purposas of the milling and rolurtion of ores, luring the period of their heneficial use, under such rules and resulations as may le prescrilied by the Secretary of the Interior and subject to the laws of the state or Territory in which said reserves are respectively situater.

SEc. - . 'That all money rerejvel from the sale of amy products or the use of any land or resomres of said forest resorves shall he rovered into the Treasury of the Enited States, and for a jeriod of fire reals fom the passage of this acot shall constitute a special fund avilable, until expended, as the Necletary of Igriculture may dilect. for the potectim. anministration, improvement. and extension of Folderal forest reserres.

Approverl. Felnuary 1, 190\%.

Ly this act the administration of the federal forest reserves is transfered to this Department. Its movisions will le rarrical out through the Forest Service. moler your immerliate supervision. Vou have already tentatively negotiated the trinsfer with the ('ommissioner of the Genelal Lind Office. whose jowers and duties thus transfered I asign to you. Entil otluervise instructed. you will submit to me for approval all guestions of organization, sales, jermits. and privileges, except surh as are entusted by the present regulations to field officers on the gromnd. Ill oflicers of the forest reserve service transferped will be subject to your instrurtions am will report directly to you. You will at once issue to them the necessing notice to this efferet.

In order to farilitate the mompt transinction of business upon the forest reserves and to give effect to the general policy outlined below, you are instructed to recommend at the earliest jucticable date whaterer changes may he necessary in the rules and regulations governing the reserves. so that I may. in accorlance with the provisions of the ahove act. delegate to rou and to forest reserve officers in the field so murlo of my anthority as may he essential to the prompt transartion of husiness and to the administration of the reserves in acorolance with local needs. Tutil sureln revision is made the present rules and regulations will remain in force, except those relating to the receipt and transmittal of moneys, in which case special fiscal agents of this Department will perform the duties heretofore rendered hy the receivers of local land offices in accordance with existing laws and regulations. The chief of records. Forest Service, is hereby designated a special fiscal agent. and rou will direct him at once to execute and submit for $11 y$ approval a bond for $\$ 20.000$. 
On December 17,1904 . the I'resident signed the following order :

"In the exercise of the power rested in the President by section $175:$ of the Revised Statutes, and acts amendatory thereot :

"It is ordered. That all persons employed in the field and in the District of Columbia in the protection and administration of forestry reserves in or under the General Land Office of the Interior Department' be classified and the civilservice act and rules applied thereto, and that no person be hereafter appointed, employed, promoted, or transferred in said service until he passes an examination in conformity therewith, unless specifically exempted thereunder. This order shall apply to all officers and employees, except persons employed merely as laborers, and persons whose appointments are confirmed loy the Senate."

This order classifies the whole Forest Reserve Service. now transferred, and places it under the civil-service law.

In the administration of the forest reserves it must be clearly borne in mind that all land is to be devoted to its most productive use for the permanent good of the whole people and not for the temporary benefit of individuals or compinies. All the resources of forest reserves are for use, and this use must be brought about in a thoroughly prompt and businesslike manner, under such restrictions only as will insure the permanence of these resources. The rital importance of forest reserves to the great industries of the western states will be largely increased in the near future by the continued steady adrance in settiement and derelopment. The permanence of the resources of the reserves is therefore indispensable to continued prosperity, and the policy of this Department for their protection and use will invariably be guided by this fact, always bearing in mind thit the conservative use of these resources in no way conflicts with their permanent ralue. You will see to it that the water, wood, and forage of the reserves are conserved and wisely used for the benefit of the lomebuilder first of all, upon whom depends the best permanent use of lands and resources alike. The continned prosperity of the agricultural. lumbering, mining, and live-stock interests is directly dependent upon a permanent and accessible suplyly of water, wood, and forage, as well as upon the present and future use of these resources uncler businesslike regulations, enforced with promptness. effectireness, and common sense. In the management of each reserve local questions will be decided upon local grounds; the dominant industry will be considered first. but with as little restriction to minor industries as may be possible; sudden changes in industrial conditions will be avoided by gradual adjustment after due notice: and where conflicting interests must be reconciled. the question will always be decided from the standpoint of the greatest good of the greatest number in the long run.

These general principles will govern in the protection and use of the water supply, in the disposal of timber and wood. in the use of the range, and in all other matters connected with the management of the reserves. They can be successfully applied only when the administration of each reserve is left rery largely in the hands of the local officers. under the eye of thoroughly trained and competent inspectors.

Very respectfully,

James WiLson, Secretary.

Senator Heyburn to Mr. Pinchot.

\section{Wallace, Inaho, May 15, 1905.}

DEAR SIR: I am just in receipt of your letter of May 4, in which you call my attention to the map. of which you gave me a copy, with certain proposed new forest reserves outlined, and in which you say, "I find that errors in the location of towns are responsible for most of your protests against these reserves, and that the outlines of the reserves are drawn as they were recommender, and that the draftsman did not alter any feature printed on the original map." I am preparing as rapidly as possible a reply to your answer to my protest. I have found an accumulation of public and personal business await- 
ing me here, and have not been able to proceed as rapidly in the preparation of my reply to your answer as I expected to do. I will. however, within a very few days forward a complete reply to the President, which will be called to your attention.

I desire that any action be deferred until my reply is received, as I am making the best possible effort in hastening it.

I do not desire, upon any showing as yet mate, to relax the vigor of ny protest against the reserves as objected to.

Yours, truly,

Hon. Gifford Pinchot,

Washington, I). C.

IV. B. Hevburs.

['Telegram.]

Senator Heyburn to the President.

The President, Washington, I). ('.:

Wallace, Inaho, May 16, 1905.

I am preparing a careful reply to presentation of Idaho Forest Reserve questions as presented by Mr. Pinchot and Senator Dubois. Please defer further action until I can complete my work, which I am pressing with all possible rapidity. consistent with a thorough and proper presentation of the matter.

IV. B. Heyburn.

Mr. Pinchot to Senator Heyburn.

Wasimgton, June 3, 1905.

Mr Dear Senator: Upon my return to Washington I hasten to answer your letter of May 15 , in which rou ask that action on certain proposed forest reserves be deferred. There is, I am afraid, nothing I can to in the premises. Upon the expiration of the time which was agreed upon; the matter went to the President, and it is now entirely in his hands. The question seems to have been pretty well thrashed out, and I doubt whether, in any event, the final outcome would be affected by further delay. In accordance with our agreement, the matter has, howerer. passed entirely out of my hands.

Very sincerely, yours,

Hon. W. B. Herburx,

Giffond Pinchot, Forester.

Wallace, Idaho.

Senator Heyburn to Mr. Pinchot.

Wallace, Id aIIO, June 1.3, 1905.

Dear Mr. Pinciotot Your letter of June 3 is at hand, and in reply I would say that the matter went to the President before the time had expired in which I was entitled to file a reply, which reply I was preparing when advised of the action taken by the President. Is 
you say, perhaps the outcome would not have been affected by further delay, but it is my intention to carry this controversy where the Constitution of the United States placed it, together with all questions concerning the public lands-that is, through Congress. What little of Idaho remains to constitute a State will still a fford fighting ground upon which to stand against the violation of the contract of statehood and the infringement upon the rights of citizens to select their own homes.

I feel that an outrage has been perpetrated upon the State and upon the people, and I am not so constituted as to yield to such condi .tiors without further action.

Sincerely, yours,

Hon. Giffori) Pincho't,

IV. B. Hejturn.

Bureau of Forestry, Washington, D. C.

Mr. Pinchot to Senator Heyburn.

Wasmingtox, June 22, 1905.

My Dear Sexator: On my return to Washington I find your letter of June 13. I am sorry to learn (what I did not know) that the Idaho proclamations went to the President before the end of the thirty days, but if so the Land Office is responsible.

I am not without hope that your feeling toward the reserves in Idaho may be somewhat modified by the new regulations, of which I shall take pleasure in sending you a copy just as soon as they are printed.

I am not without hope, also, of having the pleasure of seeing you again in Idaho this summer. Very sincerely, yours.

Gifford Pixchot,

Forester.

Hon. IV. B. Heyburs.

Wallare. Idaho.

The following correspondence relates to the period of time that the proclamations were held in the General Land Office.

Commissioner of the General Land Office Richards to Secretary Hitchcock.

Wasmington, D. C.. May 1\%, 190.).

THE BITTER ROOT FOREST RESERIE, IDAHO AND MIONTANA-PROPOSED CHANGES IN BOUNDARIES.

SIR: Inclosed herewith is office letter " R," dated March 31, 1905, submitting for your consideration the draft of a proclamation to change the boundaries of the Bitter Root Forest Reserve in Idaho and Montana, in accordance with recommendations made by the Department of Agriculture.

The inclosed letter and draft of proclamation were press-copied 
here and prepared for mailing on March 31. 1905, but after being so prepared were withheld, by agreement with the Forester of the Department of Agriculture, pencling the filing here by Hon. IV. B. Hevburn. United States Senator, of his protest against the proposed addition to sa id reserve of certain lands in Idaho.

$\mathrm{By}$ letter to this office dated April 21, 190.5, which is herewith inclosed, Senator Heyburn protested against the proposed addition of Idaho lands to the Bitter Root Forest Reserve, as contemplated by the inclosed draft of a proclamation, and against other proposed reservations of Idaho lands for forestry purposes, which are now !nder consideration here and will soon be made the subjects of recommendations to the Department. Senator Heylurn desires that his protest be considered by the President, and according to the agreement with Senator Heyburn and the Forester said protest is forwarded for consideration.

Said office letter dated and press-copied on March 21, 1905. and the accompanying draft of proclamation are now transmitted in this usanner in order to aroid confusion of the press-copy records of this office.

Very respectfully.

The Secretary of tile INterior.
IV. L. RichinRIs, Comm swioner.

Commissioner of the General Land Office Richards to Secretary Hitchcock.

Washington, D. C., 1/ay 1\%, 1905.

PROPOSED IDAHO ADDITION TO THE YELLOWSTONE FOREST RESERE.

SIR: Inclosed herewith, for your consideration, is a clraft of a a proclamation to add certain lands in Idaho to the Yellowstone Forest Reserve. ***

The records here disclose no reason why the lands should not be added to the Yellowstone Forest Reserve. and. in riew of the statements and recommendation of the Acting secretary of Agriculture, I have the honor to recommend that the inclosed draft of proclamation, which has been approved by the Forester. be signed by the President.

With my letter to the Department, dated May 17, 1905, submitting the draft of a proclamation to change the boundaries of the Bitter Root Forest Reserve. I transmitted a letter from Hon. W. B. Heyburn, United States Senator, protesting again st several proposed reservations of Idaho lands for forestry purposes. but no objection has been presented here by Senator Herburn against the proposed addition to the Yellowstone Forest Reserve. Very respectfully.

IV. A. Richards,

Commissioner.

The Secretary of the Interior. 
Commissioner of the General Land Office Richards to Secretary Hitchcock.

Washington, May 19, 1905.

PROPOSED HEXRYS LAKE FOREST RESERTE, IDAHO.

SIR: Inclosed herewith. for your consideration, is a draft of a proclamation to establish the Henrys Lake Forest Reserve. in Idaho.

The records of this office disclose no reason why the reserve should not be established as proposed, and, in riew of the statements and recommendations of the Secretary of Igricultura. I have the honor to recommend that the accompanying draft of a proclamation, which has been approved by the Forester, be signed by the President.

With my letter dated May 17. 190\%, submitting the draft of a proclamation to change the boundaries of the Bitter Root Forest Reserve, I transmitted a letter from Hon. IV. B. Herburn. United States Senator, protesting against several proposed reservations of Idaho lands for forestry purposes, including the proposed Henrys Lake Forest Reserve. I copy of that portion of Senator Heyburn's letter relative to the proposed reserve is herewith inclosed.

Very respectfully,

\section{A. RichiRDS.}

Commissioner.

The Secretary of the Ixterior.

Commissioner of the General Land Office Richards to Secretary Hitchcock.

Wasmingtox, May 19, 190:5.

PROPOSED WEISER FOREST RESERIE, ID.AHO.

SIR: Inclosed herewith is a draft of a proclamation to establish the IVeiser Forest Reserve in Idaho.

The records of this office disclose no reason why this reserve should not be established as proposed, and, in view of the statements and recommendation of the Acting Secretary of Agriculture, I have the honor to recommend that the inclosed draft of a proclamation, which has been approved by the Forester, be signed by the President.

With my letter clated May 17. 1905, submitting the draft of a proclamation to change the boundaries of the Bitter Root Forest Reserve, in Idaho and Montana, I transmitted a letter from Hon. W. B. Heyburn, United States Senator. protesting against several proposed reservations of Idaho lands for forestry purposes, inchuding the proposed Weiser Forest Reserve. Inclosed herewith is a copy of that portion of Senator Heyburn's letter relating to the proposed TVeiser Forest Reserve.

$$
\text { Very respectfully, }
$$

W. A. Richards, Commissioner.

The Secretary of the Interior. 
Acting Commissioner of the General Land Office Fimple to Secretary Hitchcock.

\author{
DEPARTMENT OF THE INTERIOR, \\ General Land Office, \\ Washington, D. C., May 26, 1905.
}

PROPOSED SAWTOOTI FOREST RESERTE, IDAHO.

SIR: I am in receipt, by reference from the Department on May 24, 1905, of a letter from the Acting Secretary of Agriculture, dated May 19, 1905, submitting a map of the proposed Sawtooth Forest Reserve, Idaho.

With my letter dated May 17, 190.5, submitting the draft of a proclamation to change the boundaries of the Bitter Root Forest Reserve in Idaho and Montana, I tramsmitted a letter from Hon. W. B. Heyburn, United States Senator, protesting against several proposed reservations of Idaho lands for forestry purposes, including the proposed Sawtooth Forest Reserve. Inclosed herewith is a copy of that portion of Senator Heyburn's letter relating to the proposed Sawtooth Forest Reserve.

The records of this office disclose no reason why this reserve should not be established as proposed, and, in view of the statements and recommendation submitted by the Department of I griculture. I respectfully recommend that the inclosed draft of a proclamation, which has been approved by the Forester, be signed by the President.

Very respectfully.

The SECRETARY OF THE INTERIOR.

J. H. Finiple, Acting C'ommissioner.

Acting Commissioner of the General Land Office Fimple to Secretary Hitchcock.

WAshington, May $9 \%, 1905$.

PROPOSED PAYETTE FOREST RESERIE, IDAIIO.

Sin: Inclosed herewith is the draft of a proclamation to establish the Payette Forest Reserve in Idaho.

Writh my letter to you, dated May 17, 1905, submitting the draft of a proclamation to change the boundaries of the Bitter Root Forest Reserve in Idaho and IIontana, I transmitted a letter from Hon. II. B. Heyburn, United States Senator, protesting against several proposed reservations of Idaho lands for forestry purposes, including the proposed Payette Forest Reserve. Inclosed lerewith is a copy of that portion of Senator Heyburn's letter relating to the proposed Payette Forest Reserve.

is stated in the inclosed report nearly all this proposed reserve is under temporary withdrawal.

The records of this office disclose no reason why this reserve should not be established as proposed, and, in view of the statements and recommendation submitted by the Department of Agriculture, I have 
the honor to recommend that the inclosed draft of a proclamation. which has been approved by the Forester, be signed by the President. Very respectfully,

The Secretary of the Interior.

J. H. Finple, Acting Commissioner.

\section{Acting Commissioner of the General Land Office Fimple to Secretary Hitchcock.}

$$
\text { Wasmington, June 5, } 1905 .
$$

PROPOSED CASSIA FOREST RESERTE, IDAHO.

Sin: Your letter to this office dated April 27, 1905. transmitted a letter from the Secretary of Agriculture inclosing two maps of the proposed Cassia Forest Reserve. Idaho, and report thereon by the Burean of Forestry. The Secretary of Agriculture, by his letter, recommends the establishment of the reserve within boundaries as shown on the maps, provided such action is consistent with public policy, and you direct that. if on examination the lands are found to be public lands and no good reason to the contrary exists, a draft of a proclamation to establish the reserve be prepared and transmitted to the Department.

According to an agreement with the Forester and Hon. IV. B. Heyburn, United States Senator, action in this matter was suspended for a period of thirty days in order that Senator Heyburn might present his objections to the proposed reserve.

The chief features of this proposed reserve are liscussed as follows in the report submitted by the Secretary of Igriculture:

$$
\text { LOCATION AND AREA. }
$$

The proposed Cassia Forest Reserve is situated in the southern part of Cassia County and embraces the rolling mountainous area known as the shoshone Mountains. The lands in question are located in a square block just north of the Nerada line, in townships 13 to 16 south, ranges 17 to 21 west of the Boise base line and meridian. The proposed reserve includes about 14 townships or 323,520 acres as planimetered from the camp.

\section{TOPOGRAPHY.}

The general topography is low, rolling mountains, standing about 1,000 feet above the surrounding flat country. Long. flat-topped ridges, separated by fairly deep canyons, extend in a northerly and southerly direction from the main divide, which runs northwesterly and southeasterly. The lands rise abruptly from the plains on the east and gradually on the west, giring the area the appearance of a small plateau which has been heavily eroded and formed into the series of ridges.

*
*

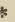

INDUSTRIES.

The ranchmen in the ricinity of the proposed reserve are dependent upon it for fuel, fencing, and house logs, and also, to a small extent, for dimension stuff. which is cut at the mill on Trapper Creek. 'The settlers who are coming in on the Twin Falls lands, like all homeseekers, have more time than moner, and have to depend on the country for fencing and fuel. The lands included within the proposed reserve are their nearest timbered lands, and ther are now removing quantities of material from the area. 
One of the principal objects of the establishment of this reserve is stated to be the proper regulation of grazing on the lands. It appears from the report (pp. !)-13) that such regulation is necessary to prevent the serious injury, if not the total ifestruction. of the area as a watershed and for forestry purposes as a result of the serious controversy now existing as to this range hetween the cattle owners and the sheep owners. each class endearoring to exclude the other from the use of the lands.

On A pril 22. 1905, yon referred to this office a letter from Senator Heyburn. relating to this proposed reserve. which is as follows:

Mr. A. J. Harrell, whose family resides near san Francisco, who rotes in Vevala and ranges attle in ldaho, tells me that he is the ownel of s.00o acres of land in Idaho, $1+0,000$ acres in Nevada. and large tralcts elsewhere, and that he wants the Government to reate a forest reserve of about 11 townshiph on the headwaters of Rock ('reek. Shoshone Creek and that vicinity in c'assia county, Idaho. He is a cattleman. He silys there is great danger that the settlers on the pulnlic lands in Idaho lower down on these streams will need the timber for building houses, etc.. during the coming rears. and he wants the forest reserve created so that the timber will not he avaibale to them. He has made a formal application and adrises me that the Department has reported farorahly upon it. The interest of Mr. Harrell in the welfare of Iolaho and its citizens seems to be intense. Wairing what mily be excused as a natural (curiosity as to how one man has obtained title to so much land. I would suggest that the privilege which he seens to be exercising as an occmpint of the lands of several states for eattle purposes is one that should be incuired into. IIow a man can get 8.000 acres of land in Idaho, the greater part of which is unsurveyed. I do not know, but I would suggest that appeals for the protection of Idaho's interests should come from loliho's citizens and representatires. and that the titles to this land claimed by Mr. II anrell be induired into. I ran not concede the propriety of creating forest reserves under such influences.

said letter was referred here with instructions to institute an investigation to ascertain how A. J. Halerell. mentioned in the letter. obtained title to such large bodies of land as allegered. Oflice letter P to your. dated April zof, 190\%, reported that sipecial Agent II. H. Soliwartz had been directed to make invertigation and report as to Mr. Harrell's acopuisition of lands, and said letter P' contained the following paragraph regarding sonator Heyburn's statements in relation to this proposed reserve:

With respect to said proposed forest reserv the oflice would state that it has no record thereof. but that it understands that steps are being taken to establish such reserve. In view of the statements made in the senator"s letter it would appear that an investigation is necessary to determine the conditions under which said reserve is proposed to be created. This pirticular phase of the matter is submitted for such consideration as may be deemed proper.

The position of A. J. Harrell, a cattle owner, with regard to this proposed reserve, and the position and sentiment, generally, of both the cattle owners and the sheep owners are fully discussed in the report submitted by the Secretary of Agriculture. It appears from the report that Mr: Iarrell clic, in fact, favor the reserve in the belief that after its establishment the sheep would be excluded from the range. But this will not result, as shown by the plan outlined in the report for administering the reserve. The plan of administration proposes to bring about an equitable assigmment of the range to the eattle owners and sheep owners, and to place the necessary restrictions upon both cattle grazing and sheep grazing.

Regarding the ownership of lands in this proposed reserve. I have the honor to report that, with the exception of the school sections involved, all the lands are shown by the records of this office to be 
owned by the United States. About 2.500 acres. in scattered tracts. and all unsurvered, are covered by forest reserve lien selections made by A. J. Harrell prior to .June 6,1900 , while unsurvered lands were -ilbject to such selections.

In addition to the lands selected by Harrell. about 280 acres of unsurveyed lands in the proposed reserve are covered by forest reserve lieu selections made by other parties. Most of said selections are made in lien of lands in sections 16 and 36 in Califormia, and the final approval thereof is withheld under order dated November 21 . 1903, and subsequent orders.

As this proposed forest reserve is comparatively free from adverse claims, and the records of this office disclose no reason why the reserve should not be established. I have, as directed by you. prepared the draft of a proclamation, herewith inclosed, to establish the reserve as recommended by the secretary of Agriculture. and I have the honor to recommend that same be signed by the President.

Duplicate hereof is inclosed, and the letters from the Secretary of Igriculture, with accompanying papers. is herewith returned.

Very respectfully.

J. H. Finple. Acting Commissioner.

The Secretary OF the Ixterior.

\section{Governor Gooding to Secretary Hitchcock.}

state of Id.hHo. Exeoutive Office, Boise. Irlaho, 1 pril 24. 190.5.

DeAr SIR: I have the honor of acknowledging receipt of your favor of April 15, inclosing lists of lands in shoshone withdrawals. I would be glad if you could have sent me copies of all proclamations. by the President relative to the withdrawal of public lands within the State of Idaho for the purpose of creating forest reserves.

In regard to recent withdrawals that have been made by the Presidential order. I desire to call your attention to the importance of this matter to this State in an adrerse way. This State has many thousands of acres of land still to select of the land endowments granted rarious State institutions br the United states. If the new forest reserves talked of are established it will practically prevent the State from securing lands sufficient to make up these grants. Under the granting acts none of the lands selected by the State can ever be sold for less than \$10 an acre, and unless the State is given an opportunity to select lands that will be included within the proposed reserves. if they are established. lands of that value can not be obtained.

I sincerely trust that the National Administration will make a careful investigation of this matter before these forest reserves are established as contemplated. I feel assured that if such an investigation is made this injustice will not be done the State of Idaho and its people.

I have the honor of being. yourn, very truly.

F. R. Goodng, Governor.

Hon. E. A. Hiтchсоск,

secretury of the Interion. W'ashington, I). C. 


\section{Acting Secretary of Agriculture Hayes to Governor Gooding.}

MAY 10, 1905.

SIR: I am in receipt, by reference from the homorable the secretary of the Interior, of your letter of April 24, in regard to temporary withdrawals of land in Idaho for forest-reserve purposes.

In accordance with your request, I am olad to inclose a State map showing in black those areas which are at present withclrawn, pending decision on the advisability of including them in permanent forest reserves. These withdrawals were made by the homorable the Secretary of the Interior in accordance with my recommendations. 'The President acts only on the final establishment of forest reserves, not on temporary withdrawals.

If the State desires to place its selections on timber lands alone, the proposed forest reserves, if finally created, will of course have the effect of withdrawing certain areas from the privilege of selection. The State. however. would not lose its right to school lands within the reserves nor would it be denied the right of indemnity selection for such lands in case it wished to exchange them.

I assume that your protest against the creation of additional forest reserves is based principally on the fact that 50,000 acres still remain mselected from the state's varions grants. This Department has no intention whaterer of recommending action that would be prejudicial to the permanent good of the State's resomres: in fact, the chief object of forest reserves is to protect and wisely use these resources with special regard to the lasting prosperity of local interests. In my judgment, it may be asked with reason whether the present policy of the State in reference to the disposal of its timber is in accordance with the best permanent good of the many important interests involved. It is apparent that the State and Federal govermments are working along somewhat different lines; the State coinsiders chiefly present financial returns, overlooking to a large extent the ultimate result of this comse of action: the Federal Gorermment, on the other hand, looks ahead to supplying many great industries with an adequate supply of timber. wood, water, and range in the futme, and this it aims to do, at its own expense, by protection and wise use at the present time. Please let me again emplasize the fact that all the resources of forest reserves are of immediate use. for the use, primarily, of local interests, and for such use as will insure permanency.

After full consideration of the matter I an convinced that the establishment of forest reserves in Idaho will not in any way act against the best interests of the State, but will, on the contrary, prove an indispensable help to the substantial prosperity of the lumbering, agricultural, mining, and live-stock industries.

Very respectfully,

The Governor of IDAHo.

IV. M. HaYs, Acting Secretary.

The President to Senator Heyburn.

The White House,

Washington, June 1.3, 1905.

Mr Dear Senator Heyburn: With your recent letter were several newspaper clippings from Idaho papers on the subject of forest 
reserves, which, you tell me, indicate the sentiment in your state on the forest-reserve question. With few exceptions, the articles, though the writers do not always seem to know it, are in direct accord with the present policy of the Gorernment in the establishment of national forest reserves. The various writers agree that forest reeserves in southern Idaho are absolutely essential to the general prosperity of that region. It is admitted that there the forests must be protected and wisely used for the regulation of the water flow and for the benefit of the settlers on vast areas of arid lands soon to be irrigated. This sentiment speaks well for the work of the Forest Service in this region and seem to indicate that the recommendations of its field men are so far heartily approved, notwithstanding the fact that you yourself have opposed. by written protest. the establishment of each and every one of the new forest reserves in southern Idaho.

It is said in these articles that some pine lands will produce excellent crops after the timber is removed. This I can readily believe. If such lands are included in forest reserves, it will be the Government's policy to open them to settlement, by elimination or otherwise, just as soon as they are shown to be more valuable for agriculture than for the production of timber or the protection of the water flow.

One specially interesting article contains an interview in which the opinion is expressed that the recent temporary withdrawal in the Coeur d'Alene and Lewiston districts was encouraged by certain large corporations, which corporations already hold large bodies of timber land in Idaho and adjacent states. It is argued that if this temporary withdrawal is made permanent these corporations will be the only people who can purchase the timber from the Government, and that they will be able to make purchases at a rery low figure and in that way stifle competition. As the gentleman who advances this opinion is expecting to locate. by means of so-called scrip, large areas of timber lands in northern Idaho in the interest of certain eastern eapitalists, it is obvions that he himself, at least. stands in no great fear of the competition of those corporations. But the fear expressed in the article is chimerical. In reality, in such cases as this, the establishment of a forest reserve offer's the fairest possible solution of the questions at issue. It present. since by far the greater part of the lands are musurveyed, the timber can not be lawfully disposed of. Just as soon as a forest reserve is established the nature timber is for sale, and for sale to the settler, the miner, and the stockman, to individuals, companies, and corporations. It is for sale in small or large amounts. Moreover. the Government is at liberty to sell as much or as little as conditions may warrant. and at such a price as circumstances may call for. But it is for sale: it is not to be stolen, and this simple fact accounts for much of the hostility to our policy. No one can force the Government to sell a single stick of timber from a national forest reserve if by so doing the best interests of all the people would be injured. What better guaranty is possible agaist unjust competition?

This same article complains that the homesteader can now obtain but a small rompensation for the relinquishment of his timber claim; but such a so-called homesteader is not a real homesteader at all. He is entitled to no sympathy. He is not the man who tills the soil, builds the home, and brings permanent prosperity to the region. 
This is the man who skins the comntry and moves on. Otherwise he would not relinquish his claim, as he admittedly does at the first favorable opportunity to those who are seeking investments in timber lands. To the real homesteader who tills the soil and builds a house to live in nothing should be grudged. He is there to stay. To the fraudulent homesteader who builds a shelter for the night under tall timber no encouragement is due. He takes all he can get and mores on. Srmpathy for such a man is sympathy for one who is engaged in framdulent transactions: if sincere it is wasted, and it is hard to see how it can be sincere on the part of one who takes the trouble to find ont the facts.

As an argument for the establishment of forest reserves in northern Idaho it has never been claimed that the forests there were important as a means of regulating the water flow. That part of the State is abundantly watered and is not concerned with questions of irrigation. It is merely a matter of bringing the Gorernment timber lands under a wise and practical system of protection with a view to providing a permanent supply of timber, first. for present needs, and, second. for future use. The immense damage already done by forest fires in this particular region is well known. Under forest-reserve management the timber is protected against fire, and simple regulations are made for lumbering. in order that the future productiveness of the forest lands may be assured. Great as the mining interests of northern Idaho are now, they are insignificant compared to what they will be in years to come. 'Timber' near at hand is absolutely essential to the permanent prosperity of this industry, and one of the chief objects of forest reserves in northern Idaho is to make sure of the forest resonres for present and future use. We wish to prevent the theft of timber and the wanton and reckless destruction of timber": and we do this in the interest of the publice of the public as it is to-day. and of the public as it will be in the future.

In your own interview, published by the Wallace Press and copied by the Lewiston .Jommal, you say that it is vour purpose to prevent the withdrawal of any portion of the lands of Idaho that are adapted to settlement and home-making purposes. If this is your only purpose ron can spare ronrself all anxiety. for the policy described is precisely the Government's policy in its temporary withdrawals for forest reserves. These withchawals are based on detailed maps prepared after careful examination in the fiels. The character of each section is shown and the fieldwork is done by men who are from training and experience thoroughly familiar with western conditions. The peculiar difficulties of this work have been fully appreciated, and in my judgment your belief that theory and inexperience have entered into the matter is a wholly mistaken one. I had you in conference with the men-men born or raised in the West, by the way-who have advised these withdrawals, and it was evident that they knew thoroughly and completely the conditions: and that the theory upon which yon. yourself, were acting was an entirely mistaken one. Let me again repeat with all emphasis that only those lands which are shown by the Forest Service to be more valuable for the production of timber or the protection of the water flow than for agricultural purposes will be included in permanent forest reserves: and that if it is afterwards proven that any lands within a forest 
reserve are of chief value for agricultural purposes, such lands, by elimination or otherwise, will be turned over to the home builder.

We are agreed on the question that public lands of an agricultural nature should be jealously guarded and freely offered for the permanent use of the real settler and home builder, and that every encouragement should be offered to bring about a substantial development in this direction. Further than this, and apparently in opposition to your own riews. I am convinced that the public forest lands should be just as carefully guarded as the public agricultural lands. and that their resources should be protected and wisely used for the best good of all the people in the long run. The contrary policy, which you seem to adrocate. is, in my judgment, a policy of destruction of the State's future assets in the temporary interest of a few farored parties.

The other clippings you send relate to party matters, and strive to make it appear that the forest-reserve question in Iclaho is a matter of political importance. Now, when I can properly pay heed to political interests, I will do so: but I will not for one moment consent to sacrifice the interests of the people as a whole to the real or fancied interests of any individual or of any political faction. The Government policy in the establishment of national forest reserves has been in effect for some time: its good results are already evident: it is a policy emphatically in the interest of the people as a whole. and especially the people of the West: I believe they cordially approve it, and I do not intend to abandon it.

Very truly. yours.

Hon. IV. B. Heyburs,

United States semate.

Theonore Roosevelt.

Senator Heyburn to the President.

Uxiten States Sexite.

Comintee ox Maneficteres.

Wallace, Itlaho, June 24, 1905.

Dear Mr. President : I have your letter of June 13, and, replying thereto. I am convinced that we are tring to accomplish the same purpose in securing to the people of Idaho their greatest benefit from the natural resources of the State. We only differ in our conclusions as to the method to be adopted. Congress has delegated to you its constitutional power orer the public lands, and within that power your judgment is governing. I have only approached you in regard to the forest-reserve question from the standpoint of a citizen of Idaho who has always taken an active part in the settlement of all questions affecting the present and future of its people. In my representations heretofore made in regard to the creation of forest reserves I have spoken only facts and have been sincere in my statements and conclusions. I hare no reason to change in regard to either. I have learned to be patient in controversy and considerate of opposition. In further consideration of the question I shall act 
in $11 \mathrm{y}$ official constitutional capacity in the semate and continne to work for such legislation as will, in my judgment, best preserver the rights of the state and its people in the present and at the same time preserve to the future its fair inheritance of assets. I have certainly given 10 gromel for even a smspicion that my sympathy is with the fraululent or pretended homesteader, either on the plains or in the forest. While I have not the slightest roubt of rour intention to do what is best for the interests of Idaho. I can not acree that this will be accomplished by the withdrawal from bona fide settlement of such large areas as indicated by the inclosed map of the state. which I have had prepared from the notes of withdrawal to date. 'The forests of the earth have in all ages afforded the habitation of the greater proportion of the human race. There are still many details of information and reason properly affecting this question which I will reserve for future consideration.

The State's grant of sections 16 and 36 for school purposes within the withdrawn areas amounts to 704.000 acres. at the price of \$10 per acre fixed hy law as the minimum. amomnting to \$5.040.000. The remaining nimeserverl land does not and never will enable the State io complete lien selections to the amount of Congressional grants to the State for elucational and other public purposes. I was instrumental in a large measure in securing the construction of State wagon roads into and through the section now withdrawn as forest reserves at an expense of orer so, 00,000 . in order that immigration might be directed to these verv portions withdrawn. The nembers of more than one legislature of Iraho thought the inducement to settlement therein sufficient to warrant the expenditure.

There is no polities in the question. I did not send the clippings referred to in vour letter to indicate partisanship. but general sentiment of a people on the ground. Howerer. You have announced as fixed policy the line of action indicated ly your recent withdrawals. and I have only the suggestion to make at this time that the existing rules shall be modified $s 0$ as to malie the burden on settlers within the influences of forests reserves as light as posible. I assure vou of my most sincere appreciation of your high standard of personal and public duty and conduct and congritulate you upon rour great achievements in the performance of the duties of vour high office. I beliere rou have done more than any other Chief Executive to place the nation upon the highest seat in the council of the nations of the earth.

While we may not always agree as to the details of method in gorermment. I do believe. Mr. President, we will concede to each other sincerity of purpose and proper motive in performance of every public or personal act. Thether I approach you as a citizen in private life or as a colleague in government I' do so with confidence in your just intentions and rour toleration of honest difference of opinion between men, each of whom bears a measure of responsibility.

With high regards for rou and sincere wishes for the welfare of the nation in your Executive care, I am, very sincerely, yours.

IV. B. Heybern. 


\title{
APPENDIX.
}

Report of Special Agent Schwartz, of the General Land Office.

\author{
Departuent OF the INTERIOR. \\ General Land Orfice. \\ Helena, Mont., July 1.3, 1905.
}

The Commissioner General Iand Office,

$$
\text { IT (askington, I). ('. }
$$

Sir: By your Div. " p," G. F. P., May 5, 1905, you directed me to make certain examinations as to the Shoshone Forest Reserve temporary withdrawal in Ilaho, the scope of which will appear from the following five questions which are taken verbatim from your above letter, and are by you therein directed principally to townships 46 and 47 north, range 5 east, and township 47 north, ranges 4 and 6 east, B. M.

I have the honor to report that in June, 1905, I made careful field examination of the above townships, and some of those adjoining; also that for the past five years I have been familiar generally with the territory embraced within the temporary withdrawal.

You ask me to examine and report:

Question 1. Whether the lands claimed as agricultural under settlement rights are in fact agricultural or timber lands?

Answer. They are, without exception, timber lands.

Question 2. If timber lands, what portions thereof, if any, could be successfully cultivated and improved if the timber were removed, and the character and productiveness of the soil?

Answer. There are about 180 squatters' cabins. within the withdrawal, and each cabin is intended to hold 160 acres until the land comes into market. About 100 of these claims have no lands susceptible of cultivation or improvement because of the steep and rocky sidehills and the shifting, gravelly stream bed in the narrow ravines. Between 40 and 50 of the claims have about 5 acres each capable of cultivation if the timber were removed, and these 5 acres are small, gravelly flats between steep mountain sides, and the flats are overlaid quite generally with from 6 to 24 inches of black soil, through which there is considerable rock showing. There are about 20 claims such as the last above, whereon the amount of land capable of improvement and cultivation will average 10 acres; and there are about 10 claims in the withdrawal where the flats widen 
out, so that from to to 80 acres am be brought muder cultivation. ()f these 10 claims. 2 are on section 3 (i, township 47 north. range 4 east. B. M.. and 3 ale on section $3($, township 77 north, range 5 east. B. M., and were " located " with knowledge that the approval of survey would find them on school lands. Such of these lands as are (apable of cultivation will produce good crops of hay. although it has been the general experience in that conntry that the small flats dry out after the timber has been remored. Oving to the mountainous character of the country, with its heary snows and cold nights, diversified agriculture is out of the question, and grasses would be the main reliance.

Question 3. To what extent, if any, have the lands claimed been cultivated. grazed, or otherwise nsed for bona ficle homestead purposes?

Answer. Frank Herlman, who has a claim in section 14 , township 47 north. lange 5 east. B. M. (which is on the north sicle of the range and near the town of Wallace, Idaho, and not in the main timber helt), has about 5 acres under cultivation; Emil Kranse, in section 26 (same township). has one-half acre in garden truck: Fred Chlman, in section 36 ( same township). has about 1 acre cleared and in garden and grass. With these exceptions. none of the lands in the withirawal have been cultivated. grazed. or otherwise used for bona fide homestead purposes.

Question t. What improvements have been placel thereon, and what are the value and character of such improvements?

Answer. Herdman has a good hewed log heuse and small barn and about 10 acres fenced: also a water-power samill. Hed principally for sawing wood from the claim for Wallace. Idaho. people. 'The remaining claims have cabins built at a cost of from \$10 to \$2.5. and with a half-dozen exeeptions none of them are habitable. 'There are over a hundred cabins without door, floor. window. or chimney, built, pen like, of unchinked logs, and with roof of brush or bark.

Question 5. Whether those claiming lands have complied in good faith with the reguirements of the settlement laws as to residence, or have maintained homes elsewhere since the assertion of such claims?

Answer. Herdman lives on his claim part of the time and also has a home in Wallace. Idaho. (He was living in Tallace in June last at the time of my two trips there.) Chlman lives on his claim, although not at home at the time I was there. Emil Kranse makes trips to his claim about once a month and stays a day or two. 'The other claimants in the withdrawal make occasional fishing or hunting urips in to the cabins. Such claimants as were mentioned by the surveror"s field notes (many of whom were " located " by the surveyors) and such claimants as have their names on the cabins or claims I have run down, and I append a list showing their actual residence and occupation. The lists are of interest. None of the claimants have complied in good faith with the requirements of the settlement laws as to residence. Uhlman is out there because he has a good timber claim and is employed by the Slate Creek Settlers' Association to bluff out any claim jumpers. Herdman's ground is probably mineral. as it is surromnded by mineral claims, and he formerly held the land as mining claims, but his principal income has been from the 
ale of wood. He has about 30,000 feet of saw $\operatorname{logs}$ now cut on the rround he is not clearing. None of the other claimants live on their laims.

I call your attention especially to the letter of Charles E. Scriber. of the Colfax National Bank, of Colfax, Wash., who, speaking for he thirty or forty claimants in township 47 north, range $t$ east, B. M., says that they made the claims in good faith so they might ile on same under the " timber and stone act:" also the affidavit of P. F. McGovern as to the Slate Creek settlers; also a list of railroad seople, several of whom told me that if they could not " timber and tone " the land they would have to lose it.

The conditions throughout the entire withdrawal do not differ from hose in the four townships especially indicated by you.

Respectfully,

\author{
H. H. SCHWARTZ, \\ Special Agent in C'harge Fourth District.
}

H. H. Schwartz, Esq..

Colfax. Wash., June 20, 190.).

\author{
Special Agent General Land Offiee, Helena. Mont.
}

DEAR SIR: Replying to yours of June 12 addressed to G. T. Sterens, will say that Mr. Sterens was not in a position to state accurately the numbers of his land, and referred the letter to me for answer, since I had the data.

The G. T. Stevens addressed is the particular G. T. Sterens who claims the SE. $\frac{1}{4}$ of section 29, township $4 \bar{\tau}$, range $\bar{\tau}$ east. Irlaho. He, in connection with some 30 or $^{4} 0$ of us. located this land on the 16th dar of June, 1902, and we have been patiently wating ever since for the time to arrive when we might file on same under the "stone and timber" act. If you will be kind enough to give us what information you can regarding the matter, you will greatly oblige many of us.

Our position is simply this: In June, 1902. we went into this then unsurvered district, and, by notice, located rertain tracts, and each summer since then have gone back and familiarized ourselves with them, hoping that the district of which survey was made, which wats in the summer of 1903 . would soon be thrown open. The inspection of the surver was not made until the summer of 1904, and now, before the district is advertised for settlement, it seems that there is talk of setting it apart for "forest reserve." If this is done, it will, of course, include us. I can not speak for many of the other parties interested, but personally I have been put to an expense of about $\$ 400$ in going back and forth to this timber, which is not very accessible; and if we can conscientiously go on and make title, I personally feel that we are entitled to some consideration, and would like to hear from you fully regarding the situation.

Thanking you in advance for an early reply, I am,

Yours, very truly,

C'HAS. E. SCRIBER.

STATE OF IDAHO.

County of shoshone, s.:

I, P. F. If Govern, being sworn, do on oath depose and say that I have a settlement claim in section :3:2, township 47 north, range 4 east, B. M., and made said settlement in May, 1902; that at present I am city marshal of Coeur d'Alene City. Idaho. for one year the 2oth of this month;

That most of the claims in township 47 north. range 4 east, were located in May, June, and July, 1902 , and were mostly by Wallace, Idaho, people; to find the lands, we ran a survey line from Wallace, at a cost of $\$ 300$; after we conr.luded to localte, we each put in $\$ 50$ to run a surver line and make other improvements, and in the fall of 1902 we each put in $\$ 10$ to build a wagon road and trail into the lands, and the business men of Wallace added to our fund until it made 


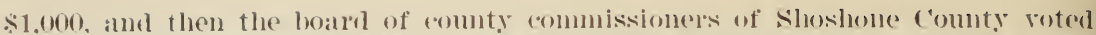

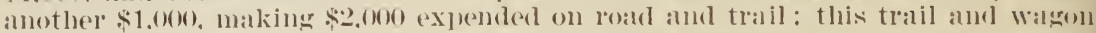

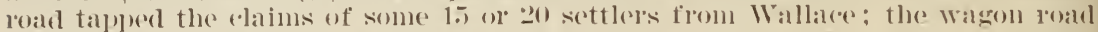
is built for a distance of + miles and the trail is huilt for 12 miles on a watgonload grade: these settlements ale what aro known as the slate crese sottlenents.

My first eabin was on section 25, and, it heing railload, I lebocated on section

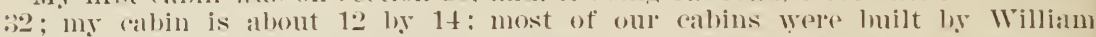
Fisher, an old miner and jospector here in the foem d'Alenes, and his con-

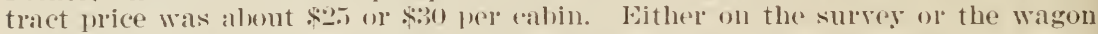

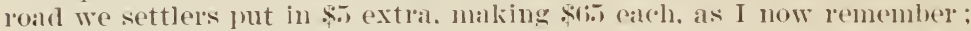

That in andition to the main trail there ale now luanch trails to a great many of the claims ;

That in the summer of 1904 we ormangel the slate creek settlers" Association, (omposed of : () men laving clains thele: this association was organized for the purpose of froterting our elaims from forest fires. and to malie implovements wherever necessiry and also to prorent claim jumping on slate ('reek;

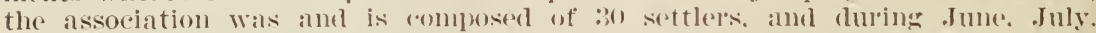
August. September, and November ("ilch (with a for exceptions) contributer \$it per month for the hire of four mon to loutrol slate creeli and prevent forest fires, also to fix up any calbius where the roefs hald hroken down or other damage had been done, and also to kerej an outlook for claim jumpers: the fomr men so employed were William Fisher. Fred I'hlman. Charles Amstutz, and one Dittman-Chlman remaining on duty until November, 1!nt:

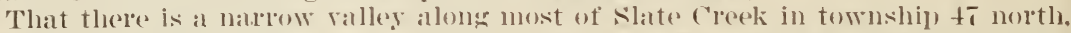
range 4 east. and in plares it is about one-half mile wide and maylos a little more. There are also nice bettom lands in section 32 . and all these lands have a nice hlack loam and decelu soil:

That sutw anemerally andes in there in Noxembel or December and usually

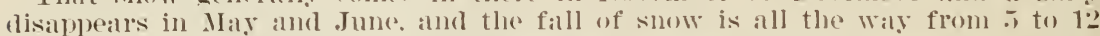

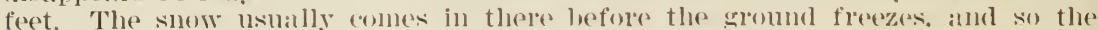
(2)romel is selelom formen :

That I have seen potatoes and small patches of regetables grown in thele. and they matmed, and I know that they will grow there fine. It is my opinion that the land in there is hetter atapted for hay than anything else, and there are fine native growtls of wild laty. wild oats. and wild peas in there:

'That of my own claim, it the timber was removel. I could plow and falm about 1.j acres. I have not seren all the relaims in there. lut there are mally better for farming than mine. If the timber was off. nearly all my claim would grow timotlyy. I roule get water on neally lalf of my raim tor irrigatimg purposes. It gets juetty dry there in the smmmer and water would help.

The settlers on slite ('reeli have no asreemont or understanding to sell omr

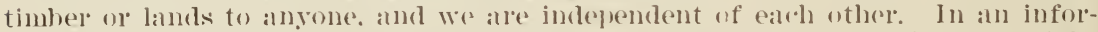
nal sort of way we liaw discussed the plan that when we got title we night lut in a mill and saw the timber ourselves and make all there is in it. but we have no contract about it-just talk. We are banderl together just to protect our separate interests, as before stited.

I. F. MCGOVER.

Subscribed and sworn to before me at Wallace. Inalio, this Jume S, 19m.

II. II. S゙(HWART\%.

special dyent. General Land office.

\section{Fxнівіт A.}

statement showing settlement claimants for lands in tounship fi north. range

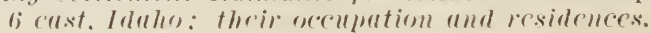

1. J. I'. O'Brien, claining land in section 19), is the general manager of the Oregon Lailway and Navigation Company and resides and has his headquarter's at Portland, Oreg. I las never lived on the land.

2. J. II. Gralnam. claming land in section 20. is the general superintentent of motive powel fol the Olegon Railway and Navigation Company ; resides alt Portland. Oreg.. and has never liverl on the land.

:). D. McDonald, claiming land in section 19, is an engineer for the Oregon 
Lailway and Navigation Company; resides at Wallace, Idaho: has nerer lived on the land.

4. F. J. Damon, claiming land in section 20, is a brakeman for the Oregon Railway and Navigation Company : resides at Moscow. Idaho; has nerer lived on the land.

5. Jack Stewart, ('laiming land in section 2-7, I did not locate; has nerer lived on the land.

6. C. II. Torrence, claiming land in sections 27 and 28 , I did not locate: las never lived on the land.

7. F. W. Ertel, claiming land in sertions 27 and 2S. I did not locate: he has never resided on the land.

8. J. E. Nessley, claiming land in sections 33 and 34 . lives at colfax, Wasll., and is a newspaper man; never lived on the land.

9. E. C. Murray, claming land in sections 21 and 28 . lives at colfax. Wash.; never resided on the lant.

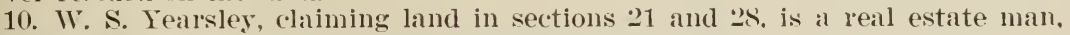
living at colfax, Wash. : has nerer resided on the land.

11. ('. W. Hess, claining land in sections 21 and 28 , formerly road master for the Oregon Railway and Navigation Company; now a tobaceo merchant at Colfax, Wash.; nevel lived on the land.

12. Thomas Neill, daiming land in sections 28 and 33. is a lawyer, residing at Colfax, Wasls.; never lived on the land.

13. George F. Cantield, (raming land in sections $3: 3$ and 34 , lives at Tekoa.

Wash.; never lived on the land.

14. G. Wr. Larue, rataning land in section 32, lives at springston, Iaho; is a foreman for the Lindsley Brothers Cedar ('ompany : never lived on the land. 15. Al. Scott. claiming land in sections :9 and 32 , lives at Tekoa, Wash.; never lired on the land.

16. H. Wr. Canfield, rlaiming land in section 29, is a lawyer, living at Colfax, Wash. : has never lived on the land.

17. S. A. Thurner, claining land in section 29, is a barkeeper, living at Lewiston, Idaho: never lived on the land.

18. Con MaGreevey, (laiming land in sections 2!) and 30, is a groceryman, living at Tekoa, Wash. ; never lived on the land.

19). P. H. Stanley, chaming land in section :30, is in the hotel and saloon business at Tekoa. Wash.; nerer lived on the land.

20. Frank Quinn, clatming land in sections:30 and :31, is the proprietor of the Quinn Hotel, in Tekoa. Wash. IIas nevel lived on the land.

21. Lee Boyer, claiming land in sections 30 and 31 , is the proprietor of the Tekoa Dry Goods company : lives at Tekoa. Wash., and never lived on the land. 2.2. Edwin Schmidt, raiming land in section 31, is a groceryman at Tekoa, Wash. Nerer lived upon the land.

These claimants. with one or two exceptions. all voted in the towns where they lived, and not in the precinct where the land is situated and not in the precinct where they should have roted if they had given their residence as that of the land claimed by them.

\section{Exhibit $B$.}

statement showing settlement claimants for lands in township y north, range 4 east, Idaho: their occupation and residences.

('They are all member's of the Slate Creek Settler's' Association, as to which see Exhibit C.)

1. James Boaz, claiming land in section 17 , is a saloon keeper at 516 Cedar. and resides at 415 sixth street, Wallace. Idaho. Nerer resided on the claim.

2. Albert Balkwill (claimed land in section 20; was until recently a saloon lieeper in Wallace, Itaho, and now lives somewhere in the Parette Valley. southern Idaho. Never lived on the land.

3. J. Balkwill, clatming land in setion 19, is a miner working in Standard mine, Wallace, Idaho. Nerer lived on the claim.

4. James Camp, claiming land in section 30 , is a wagon driver in Wallace. Idaho; hoards at Pacific IIotel. Never lived on land.

5. August Carlson, (raiming land in section 34. is a saloon keejer in and resides at Coeur d'Alene City, Idaho. Nerer lived on the land. 
6. George Chapman, claiming land in sections 8 and $\mathbf{1 7}$, is a dentist living at Colfax, Wash. Has never lived on the claim.

7. T. Dan Connor', claiming land in section 32, ex-mayor of Wallace, Idaho; now a mucker at Standard mine; lives at Wallace, Idaho. Never lived on the claim.

8. William Fishinger, claiming land in section 26, is president of the Wallace Cigar Company, and resides at 706 Cedar, Wallace, Idaho; never lived on the claim.

9. Frank Franz, claiming land in section 28, is a millwright, living at 830 ) Bank street, Wallace, Idaho; never lived on the land.

10. Charles Girton, claiming land in section 19, was formerly a policeman in Wallace, Idaho; residence unknown; never lived on the claim.

11. M. H. Hare, claiming land in section 29, resides in Wallace, and until two months ago was for several year's cashier of the Wallace Bank of Commerce; never lived on the claim.

12. Frank Herdman, claiming land in section 14, resides upon the land most of the time, also has a residence in Wallace, Idaho. IIas about 5 acres cleared and a hewed $\log$ house. Land not in the main timber belt.

13. Fred Johnson, claiming land in section 30 , is a carpenter and miner, residing in Wallace. Idaho; never lived on the claim.

14. Sam Johnson, claiming land in section 34 , is a saloon keeper at and residing at Coeur d'Alene, Idaho; nerer lived on the land.

15. Emil Krause, claining land in section 2i, is a gun and lock smith, residing in Wallace, Idaho; never lived on the land.

16. P. F. McGorern, clatiming land in section 32 , is city matrshal or chief of police of Coenr d'Alene, Idaho, where he resides; never lived on the claim.

17. Terry McLaughlin, claiming land in section 36, is a cigar maker, residing at 206 Cedar street. Wallace, Idalo; never lived on the land.

18. Dan McInnis, claiming land in section 34 , is a saloon keeper and dancehall proprietor in Wallace, Irlaho, and never lived on the claim.

19. A. P. McRae, claiming land in section 28 , is an iron worker at the Standard mine, and lives in Wallace; never lived on the claim.

20. John .J. Price, logger and manager for James Camp, resides at 613 Cedar, Wallace, Idaho: never lived on the daim.

21. Henry I'annebaker, who claims land in section 28, lives at Wallace, Idaho, and is a member of I'mmebaker Irothers, master carluenters and contractors; never lived on the claim.

22. Charles I'fitzenmier, who claims land in section 26, is a cigar maker, and lives at For; Cedar, Wallace, Idaho; never lived on the land.

23. John .J. Quinn, who claims land in section 20, is a Wallace, Idaho, policeman; never lived on the claim.

24. J. H. Sonderregger, who claims land in section 36, is a porter in Zeitfuch's saloon, Wallace, Idaho, and lives there; never lived on the land.

25. Thomas Treed, who claims land in section 16 , is a mill man at the Mammoth mine mill, Wallace. Idaho, and lives there; nerer lived on the land.

26. Hugh Toole, who claims land in section 30 , is secretary and treasurer of the Wallace C'igar Company, and a member and the president of the city council of Wallace, Itaho, where he lives: never lived on the claim.

27. Fred Ihlman, who claims land in section 36 , is care taker of cabins and ranger for the Slate Creek Settler's Association, and as such is in the township) most of the time and may live on his claim while there.

28. Sidney Yan Hook, who claims land in section 20, is a miner working at the Morning mine, Mullan, Idaho; never lived on the clain.

29. John Worums, who claims land in section 32 , lives in Wallace, Idaho, where he is a lawyer and is connected with the Security Abstract and Title Company; never lived on the claim.

There is a small $\log$ house or cabin on each of the above claims. Most of the abins were built by William Fisher on a general contract at $\$ 25$ each. They were never worth $\$ 2.5$ in labor and material. With the exception of Frank Herdman's claim and Fred Thlman's claim, these claims are not used for any jurpose, neither mining, agricultural, or grazing; and no clearing. fencing, or other work has been done preliminary to any of such uses.

These claimants, with one or two exceptions, all roted in the towns where they lived and not in the precinct where the land is situated. and not in the precinct where they should have roted if they had giren their residences as that of the land claimed by them. 
Exhibit C.

Statement showing settlement clamants for lands in tounship fi north, range 5 east. Idaho; their occupation and residences.

1. Edward schmidt, clatiming land in section 36, is a grocer living and doing business at Tekoa, Wash. Never resided on the land.

2. J. W. Hutchinson, claiming land in section 36, is a railroad brakeman on the Oregon Railwar and Navigation Company, and lives at Tekoa, Wash. Never resided on the land.

3. W. R. Walker, claiming land in sections 35 ant 36, is a saloon keeper, formerly of Tekoa. Wash.. but now living at Wilbur, Wash. Nerer resided on the land.

4. O. H. Dokkin, claiming land in section 35. I was unable to locate claimant. He has never resided on the land.

5. M. M. Taylor, claiming land in sections 26 and 35, is a hardware merchant residing and doing business in Coenr d'Alene City, Idaho. He has never resided on the land.

6. J. C. H. Pearson, claiming land in sections $2 \tau$ and 34 , is residing at Kenton, Mich., and recently acquired the settlement rights to the above land from II. E. Howes. quoted by the surveyor's returns as a settlement. Howes is a grocery merchant living in Wallace. Idaho. He has never resided on the land.

7. Horace King, claiming land in sections 27 and 34 , is a grocery merchant living and doing business at Wallace, Idaho. He has nerer resided on the land.

S. O. M. Featherstone, claiming land in sections 27 and 34 . is a single woman. residing in Wallace, Idaho, sister to Attorney II. H. Featherstone. She has never resided on the land.

9. N. D. Sellers, claiming land in section 3.5. I was unable to locate. He has never resided on the land. There is a crockery merchant in Spokane, Wash., of the same name and initials who has not answered my letter of inquiry.

10. A. J. Ramsey, claiming land in section 34 , is alleged to be a locator from Minneapolis. Minn. The-claimant has never lived on the land.

11. E. H. Roley, clatiming land in section 34 , I was unable to locate. He has never resided on the land.

12. A. Anderson, chaming land in section 3.3 , is a bridge foreman for the Oregon Railway and Navigation Company, and resides at Tekoa. Wash. He has never lived on the lind.

13. J. W. Scriber, claiming land in section 33, resides at Colfax, Wash. He has never lived on the land.

14. C. E. Scriber, claiming land in section 33, resides at Colfax, Wash., where he is cashier of the Colfax National Bank. He has never lived on the land.

15. D. W. Camplell, claiming land in sections 28 and 33 , is the general superintendent of the Oregon Railway and Navigation Company, with residence and headquarters at Portland, Oreg. He has never lived on the land.

16. George Camplell, claiming land in sections 28 and 29, I was unable to locate. He has nerer lised on the land.

17. Ed. Alrord, claiming land in section 32 . is a hartender living at Telsoa, Wash. He has never liverl on the lant.

1S. S. A. Mitchell, claiming land in section 22 . lives at Colfax. Wash., and is a clerk in the county office. He has never lived on the land.

19. H. H. Logan, chaming land in section 29. is in the dry-goods business in Helena. Mont. He has never lived on the land.

20. W. E. Grant, claiming land in sections 28 and 29, resides at Harrison, Idaho, where he is the owner of a sawmill. Ile has never liverl on the land.

21. George Sterens, claiming land in section 29, is a conductor for the Oregon Railway and Navigation Company. living in Spokane, Wash. He has nerer resided on the land.

22. G. N. Smith. claiming land in section 2S, is attorney and counsel for the Oregon Railway and Navigation Company, and lives at Portland, Oreg. IIe las never resided on the land.

23. A. M. Scott. claiming land in sections 28 and 21 , resides at Colfax. Wash., where he is a wheat buyer for the Balfour-(inthrie Company. He has nerer lived on the land.

24 . J. W. James, rlaiming land in section 28 , is alleged to be a railroad man.

I did not locate him. Ie has never lived on the land.

25. A. T. Toney, claiming land in sections $22,23,26$. and 27 , formerly lived at Colfax, Wash. Has never resided on the land. 
26. F. A. Toner, daiming land in sections 25 and 26. formerly lived at Colfax, Wash.. and never lived on the land.

27 . O. Sorenson. claiming land in sections 22 and 15 , I did not locate. He has never lived on the land.

25. A. Olson. claiming lind in sections 22 and 15. I did not locate. He has nerer lived on the land.

29. A. J. Freeberg. (daiming land in sections 21 and 22.2 I did not locate. He has nerer lived on the land.

30. I. B. Logan, claiming land in sertion 21. is a sawnill man at Harrison. Idaho: also runs a lumber yard at Rockford. Wash. He has never lived on the land.

31. A. Rustad. claiming land in section 21. I did not locate. Hle has never lived on the land.

32. Robert Jell. claiming land in section 21. is a conductor for the Oregon Railway and Narigation Company, and resides at Tekoal. Wash. IJ has never lived on the land.

33. William Bartell, claiming land in sections 20 and 21, lives at Harrison, Idaho, where he is a foremin in the Grant sammill. IIe has never lived on the laud.

34. R. B. Howard, claiming land in section 20, is a train butcher on the Orecon Railway and Navigation load, and lives at T'ekoa, Wash. Ile has never lived on the land.

35. Stella Perkins, claiming land in section 20. lives at Colfax. Wash. In an elocutionist, and has never lived on the land.

36. F. F. Darles, rliniming land in section 20, is a conductor for the Oregon Railway and Narigation Company, and lives at Wallace. Idaho. Nerer resided on land.

37. Hattie II. Crawford. claiming land in sections 19 and 18 , is a single woman, residing at Irrigon, Oregr: formerly lived at Wallace. Idaho. She has never lived on the land.

3.. Al. C. Crawford, claiming land in section 15. lives at Irrigon. Oreg: formerly lived at Wallace. Idaho. He has nerer lired on the land.

39. John Erickson, claiming land in section 17, I did not locate. He has nerer lived on the land.

40. M. O. Reed, claiming land in section $1 \bar{\tau}$, is a lawyer, residing at colfax. Wash. II has never lived on the land.

41. Wr. E. Reerl. claiming land in section $1 \overline{7}$, is a lawyer. liring in the state of Nebraska. IIe has nerer lived on the land.

42. II. P. Iongreen, claiming land in sections 15 and 16 , is a hardware man at Wallace, Idaho. IJe has never lived on the land.

43. A. W. Perler, claiming land in section 17 . is an engineer on the Oregon Railway and Navigation, and lives at Tekoa. Wash. Has not resided on the land.

14. A. Bloom, claiming land in section 16, I did not locate. He has not resided on the land.

45. O. H. Hellickson. claiming land in sections 4 and 9. I did not locate. He has never lived on the land.

46. A. Thorsen. claiming land in section 9. I did not locate. He has not residerl on the land.

47. s. I. I'lace, claiming land in section S, I did not locate. Ife has not lived on the land.

4S. O. Ioldenberg. claiming land in section 5, I did not locate. He has not lived on the land.

These claimants. with one or two exceptions, all roted in the towns where they lived and not in the precinct where the land is situated, and not in the merinct where they slould have roted if they had given their residences as that of the land claimed by them.

State of Idaho.

county of shoshome. ss:

I, Charles E. Hoyt, being first duly sworn, do on oath depose and say that I am a freight packer and prospector, having my post-office at Wallace, Idaho. and that I have prosperted and packed into the mountains and on the waters of the st. Joe and Clearwater rivers, south of Wallace, for the past fifteen years; that I halve had a settlement claim on the st. Joe in township 45 north, range 4 east, since 1894 . 
That I hare trapped in the mountains ahout the st. Joe for many winters nd have had many mining claims in that country which, with my rumning a ack train for miners. prospectors. surverors. timber locators, and Government ien. gives me a thorongh personal knowledge of practicalls all the countrs in de withdrawal of the proposed shoshone Forest lieserre.

Township 47 north. range 4 east. B. M.. lies just south of Wallace. Idaho. The ortheast one-fourth of this township is drained by Placer creek. which runs ortherls into the sonth Fork of the Coeur didlene River: the rest of the wnship is drained by slate Creek and is over the diride, the waters of slate reek ruming into the st. Joe Rirer: that part of 47 north, range 4 east. rained by Placer Creek is mineral land and has lots of mining work. There also one settler on I'lacer Creek in this town-Frank Hord. alias Herdan-who has a house, stable, and abont 2 acres of gromud (leared un: his is a ond hewed log homse and is $\frac{1}{2}$ miles from Wallace. Idaho: Hord raises garden uck and hay, and also has a small water-jower sawmill, and he sells wood 1 Wallace: his claim has alout a million feet of timber on it, and if he takes our forties up and down the creek he could get about bo acres that could be armed when the timber is off. There is about 160 acres on Placer Creek that ould be farmed if the timber was off. hut it is nearly all corered br mining aims. Hord located his land as mineral daims, and it is mineral land. On late Creek and its branches in the west and south half of this township there re alwut fifty settlement claims that I know and hare seen: these fift? are all mber claims. and of them only two claimants make any showing torard resience on the land: these two are Fred thlman. on section 36 , who has a log ouse shingled orer for siding. and a smaller log house now used as storerom. and has about 1 acre cleared and half of it in crop. Chlman's place is eadquarters for the slate Creek Settlers" Ascociation. and he works for the ssociation in the ofven season. looking after the claims and cabins. The other ttler is Emil Krause, a locksmith in Wallace. who is on his claim a few dars rery few weeks and has a good log house and about one-fourth acre cleared ad now in garden. Excepting the ahove two all the claims bave no clearings - improrements except a cabin in the timber. and the claimants seldom risit land. These claims in township 47 north. range 4 east. are all located where he merchantable timber stands and are locally known as timber claims: some E the lrest timber is on small flats along the slate creek, and if that timber ere cut off this Hat ground would do for farming. There is on the $=0$ claims, arbe. $1 \frac{1}{2}$ sections of such flat lands.

In township 47 north. range $\bar{j}$ east, B. M. there are about 100 settlement aims with cabins on: none of these claimants live there: none of these claims are any clearings or imporements therem. These claims are all located oa nd haring raluable saw timlver. and are localle known as timber claims: the atins are from 3 to 7 feet high, and few of them have any floors and many of nem hare loush thrown on for a roof. In this township the south $t$ miles of ne North Fork of the st. Joe has a valley from one-fourth to one-half mile ide. which could be farmed if it had the timber off : the rest of the torinship is eep, roks. loroken mountains, and ridges: most of the settlement claims have farming or agricultural lands.

In township 47 north. range 6 east. B. M.. the south balf is in Idaho and in ne rithdrawal: the fine timber in this township is in the nine sections in the uthwest quarter of the township and that land is drained by Frazer creet ad the East Fork. which empts into the North Fork of the St. Joe: there is no micultural land in the townhip in Idaho: all the timber lands are claimed isettlement claims, and none of the claimants live there: there is no clearing: le cabins are from 3 to $T$ feet high. and few of them could he lired in.

In township thi north. range 5 east. B. M.. the diride between slate creek and le Vorth Fork of the st. Joe runs north and south through the center of the wnship: there is little or no agricultural land in this township: no one lives the township. although there are alwut 25 settlers calvins where the sam mber stands.

The snom comes in the river hottoms about December and stars about four conths. In the hottoms the snow gets from 4 to is feet deel and on the ridges rom s to 1: feet.

subscribed and strorn to before me June 27. 19k. , in Thlman's daim. townaip $t i$ north. range $t$ east. B. M. 


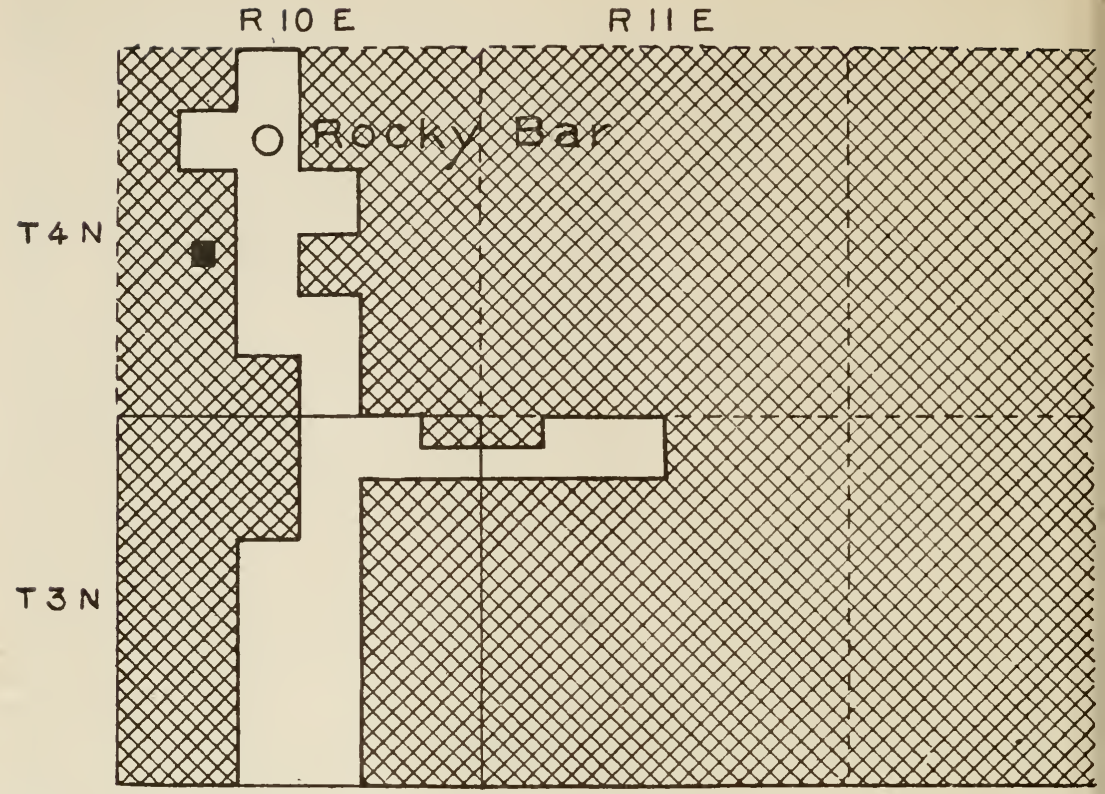

Fig. 1.-Circle shows actual location of Rocky Bar, outside the reserve; black square shows incorrect location as given by General Land office map.

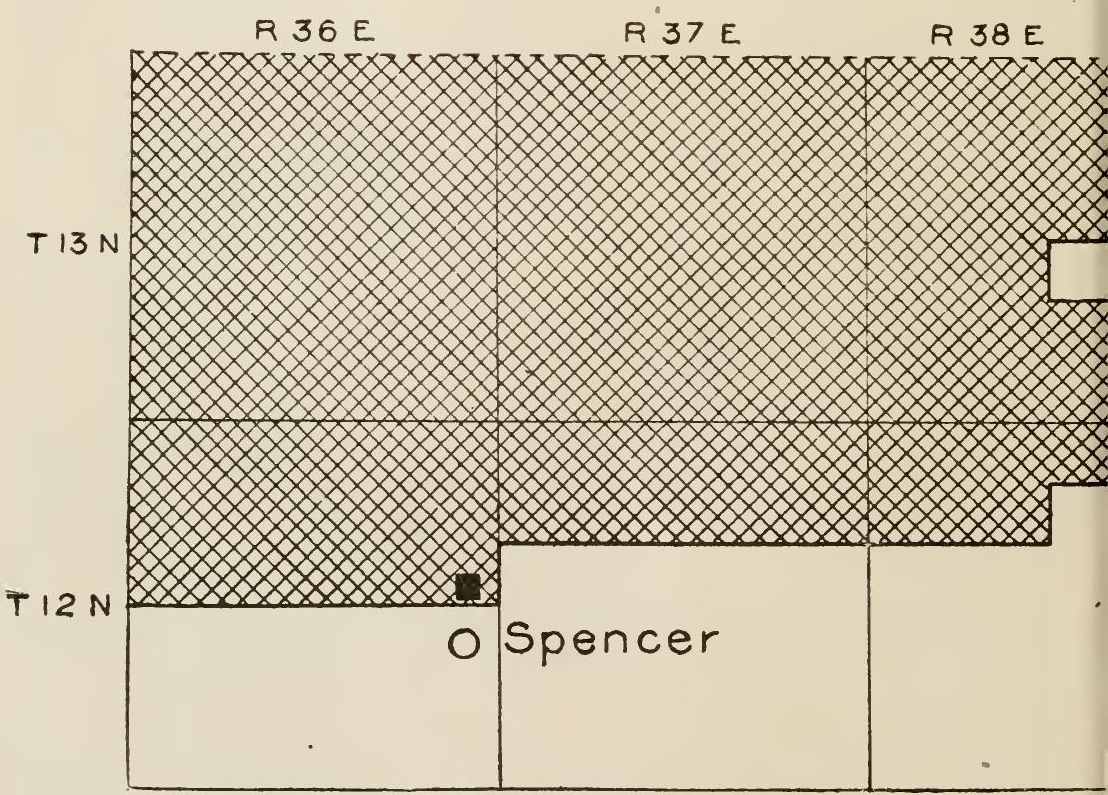

FIG. 2.-Circle shows actual location of Spencer, outside the reserve: black square shows incorrect 


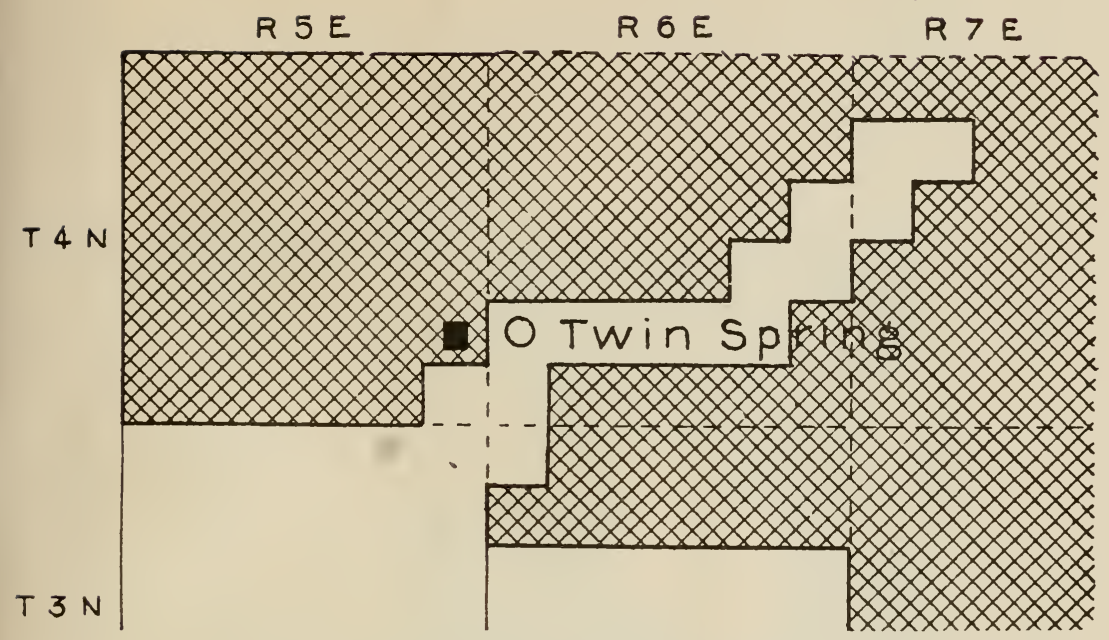

FIG. 3.-Circle shows actual location of Twin Springs, outside the reserve; black square shows incorrect location as given by General Land Office map.

T $8 \mathrm{~N}$

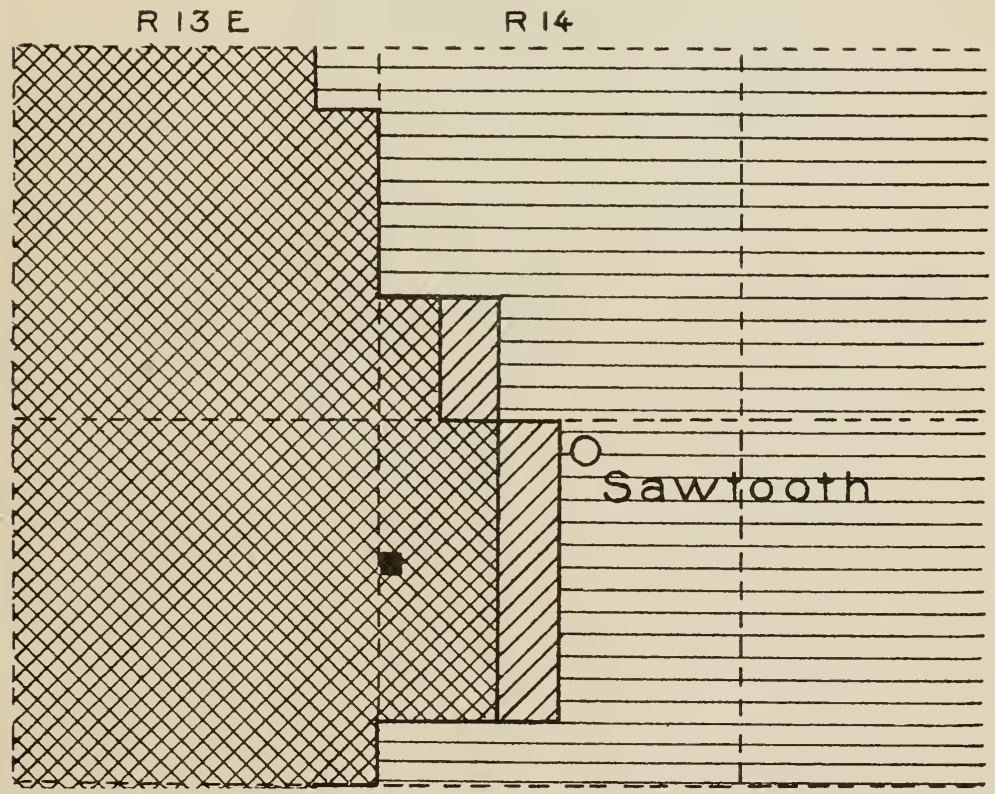

FIG. 4.-Circle shows actual location of Sawtooth, outside the reserve; black square shows incorrect location as given by General Land Office map. 


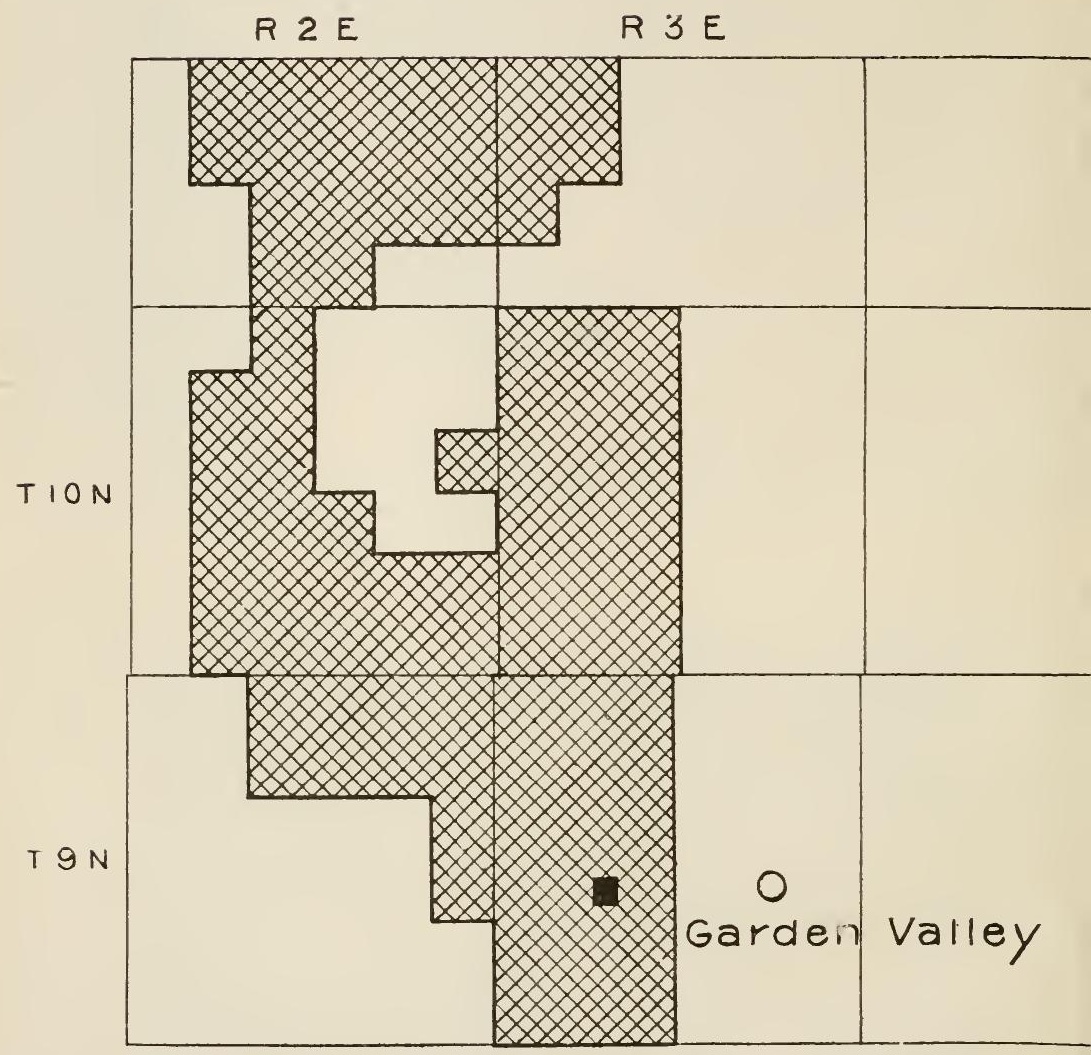

Fig 5-Circle shows actual location of Garden Valley, outside the reserve; black square show incorrect location as given by General Land Office map. 




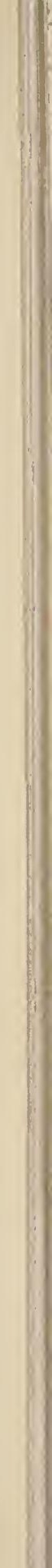




\section{RETURN FORESTRY LIBRARY}

TO $\longrightarrow 260$ Mulford Hall

642.2936

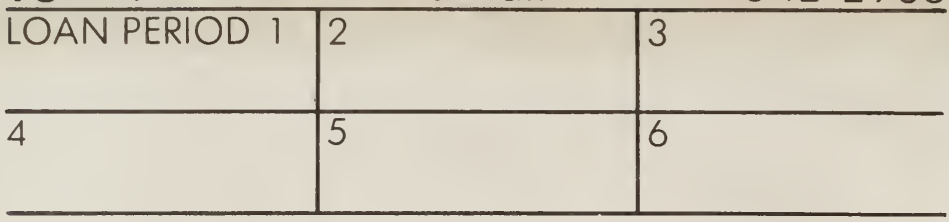

ALL BOOKS MAY BE RECALLED AFTER 7 DAYS

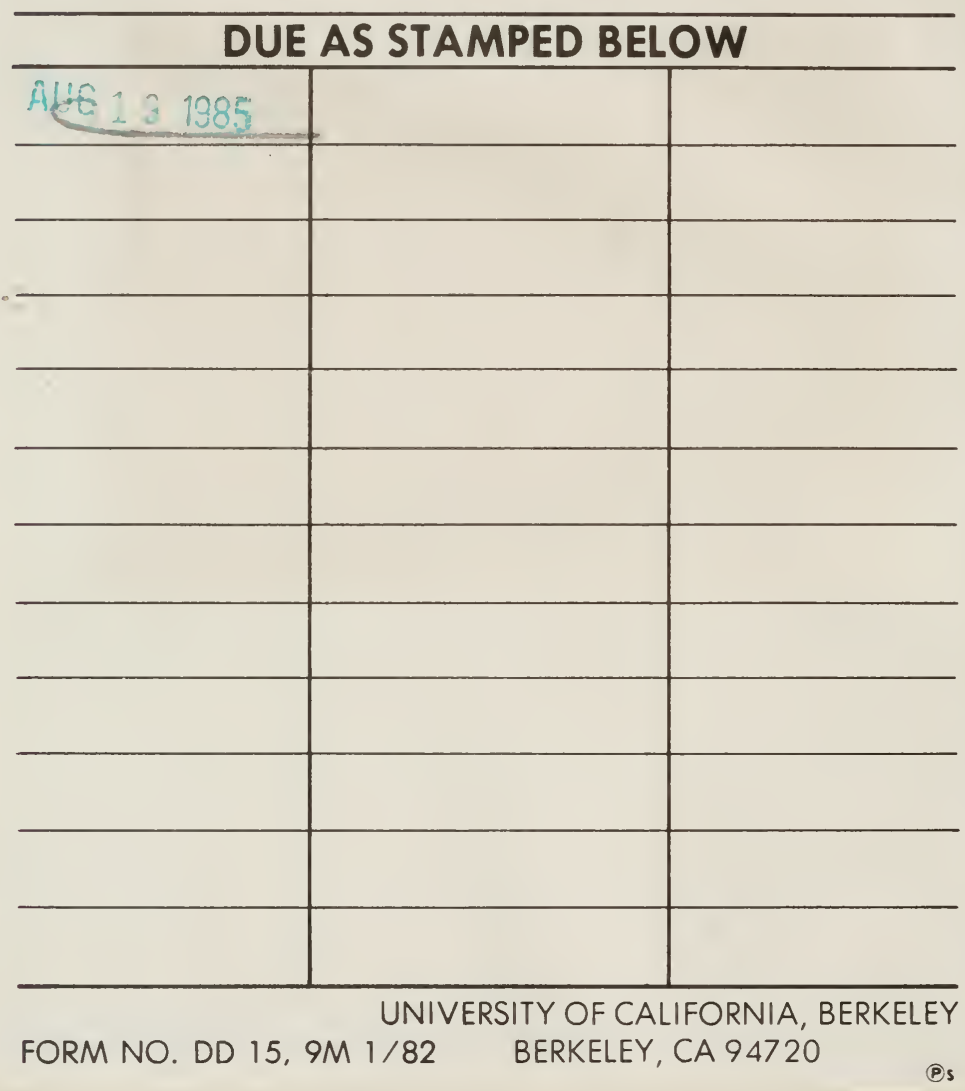




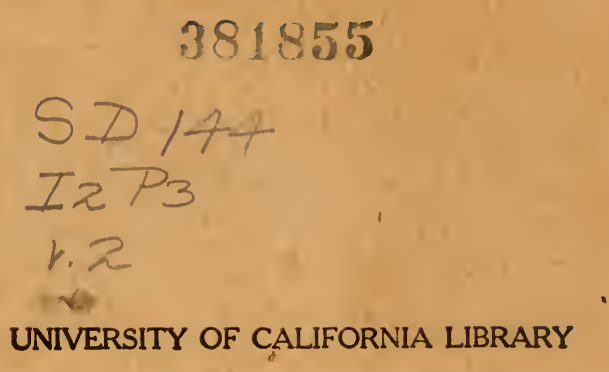

U. C. BERKELEY LIBRARIES

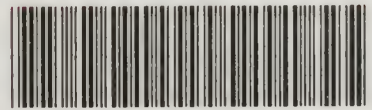

C04688496? 
